\title{
ARTICLES \\ REASON AND CONVICTION: NATURAL RIGHTS, NATURAL RELIGION, AND THE ORIGINS OF THE FREE EXERCISE CLAUSE
}

\author{
StevenJ. Heyman"
}

\begin{abstract}
One of the most intense debates in contemporary America involves conflicts between religious liberty and other key values like civil rights. To shed light on such problems, courts and scholars often look to the historical background of the Free Exercise Clause of the First Amendment. But that inquiry turns out to be no less controversial. In recent years, a growing number of scholars have challenged the traditional account that focuses on the roles of Thomas Jefferson and James Madison in the movement to protect religious liberty in late eighteenth-century America. These scholars emphasize that most of the political energy behind the movement came from Evangelical Christians. On this revisionist account, we should not understand the Free Exercise Clause and corresponding state provisions in terms of the Enlightenment views of Jefferson and Madison, which these scholars characterize as secular, rationalist, and skeptical-if not hostile-toward religion. Instead, those protections were adopted for essentially religious reasons: to protect the liberty of individuals to respond to God's will and to allow the church to carry out its mission to spread the Gospel.
\end{abstract}

This Article offers a different understanding of the intellectual foundations of the Free Exercise Clause. The most basic view that supported religious liberty was neither secular rationalism nor Christian Evangelicalism but what contemporaries called natural religion. This view held that human beings were capable of using reason to discern the basic principles of religion, including the duties they owed to God and one another. Because religion was founded on reason, individuals had an inalienable natural right to develop their own beliefs and to worship in accord with them. At the same time, that right was limited by the law of nature and reason, which required people to respect the rights of others. In this way, the concept of natural religion established both the foundations and the limits of religious liberty. This view enabled people with different religious and philosophical perspectives to find common ground. It provided the basis for a political coalition between Evangelicals, rationalist Christians, and Enlightenment

Professor of Law, Chicago-Kent College of Law, Illinois Tech. A.B. 1979, J.D. 1984, Harvard. This Article was presented at a Chicago-Kent faculty workshop in November 2019. For their thoughts on previous versions, I am grateful to Sungjoon Cho, David Franklin, Andrew Ingram, Nancy Marder, Mark Rosen, Stephanie Stern, and Cristina Tilley. Kathleen Brady and Steven D. Smith were remarkably generous with their insights and knowledge, which did much to improve the article. Sofiia Kulitska, LL.M. 2019, and Rawan Hishmeh, J.D. 2021, provided valuable research assistance. As always, I want to thank my wife, Alison Kate Baldwin, for her wise counsel. I owe a special debt of gratitude to Mandy Lee, Nicole Mszal, and other members of the Chicago-Kent library and administrative staff for their extraordinary efforts in obtaining and archiving many of the historical materials used in this Article. 
liberals that secured the adoption of state and federal constitutional guarantees for religious freedom.

The Article begins by demonstrating that natural religion and its associated ideas of natural law and natural rights were central to the intellectual world of eighteenth-century Americans. Those ideas played a vital part in many areas of thought, including political and moral philosophy, natural jurisprudence, English law, Christian and Deist theology, and even Newtonian natural science-intellectual strands that came together in the Radical Whig ideology that animated the American Revolution. Next, I explain how those ideas can enhance our understanding of the religious-liberty provisions of the first state declarations of rights; the political controversy that culminated in the passage of Jefferson's Bill for Establishing Religious Freedom in Virginia; and the debates surrounding the adoption of the Federal Constitution and the Free Exercise Clause itself. Finally, I explore the founders' views on the problem of religious exemptions from civil laws, and discuss the implications of this history for our current debates over civil rights and religious liberty-a subject that the Supreme Court recently grappled with in Masterpiece Cakeshop, Ltd. v. Colorado Civil Rights Commission, and that is before the Court again this Term in Fulton v. City of Philadelphia.

\section{TABLE OF CONTENTS}

INTRODUCTION

\section{JOHN LOCKE ON RELIGION, TOLERATION, AND THE RELATIONSHIP} BETWEEN CHURCH AND STATE.......................................................10

A. Locke on Natural Religion.................................................................10

1. The Concept of Natural Religion ............................................10

2. The Limits of Natural Religion and the Need for Revealed Religion

3. The Relationship Between Faith and Reason........................15

B. Locke on Religious Liberty and the Separation of Church and

State.

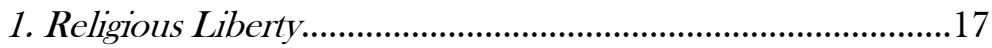

2. Separation of Church and State ................................................20

3. The Limits of Religious Liberty and Toleration .......................20

C. Conclusion ..........................................................................................22

II. NATURAL RELigion IN EighteENTh-CENTURY Thought.................22

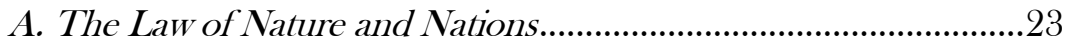

B. English Law and the Toleration Act of 1689 .................................28

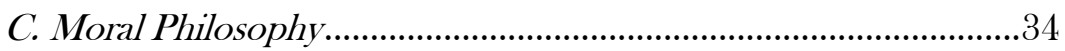

1. Sentimentalism and the Scottish Enlightenment.....................34 
2. Rationalism .38

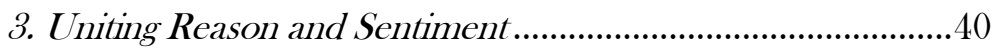

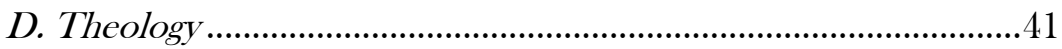

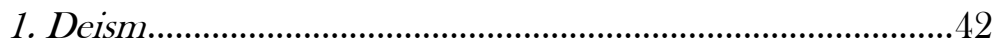

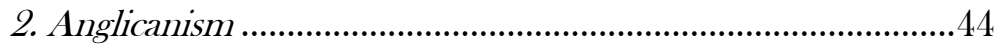

3. New England Congregationalism............................................47



F. The Radical Whig Tradition .........................................................53

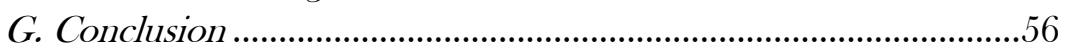

III. THE AMERICAN REVOLUTION AND THE First STATE

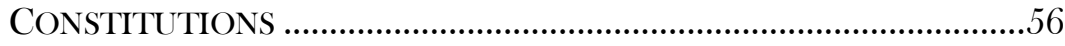

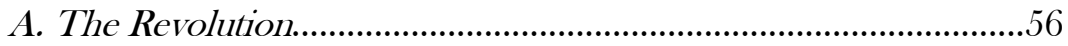

B. The First State Constitutions and Declarations of Rights..............58

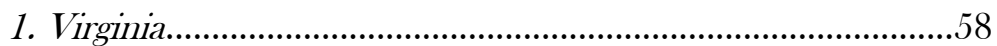

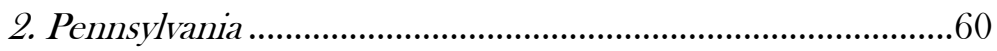

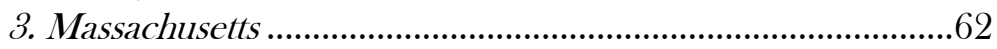

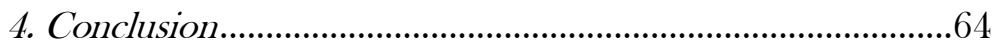

IV. THE BATTLE OVER RELIGIOUS FREEDOM IN 1780S VIRGINIA ............67

A. The Controversies of the Mid-1780s...............................................67

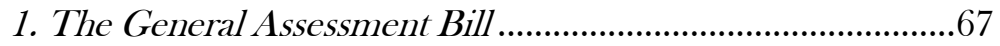

2. Jefferson's Bill for Establishing Religious Freedom..................73

B. Interpreting the Virginia Controversy...............................................76

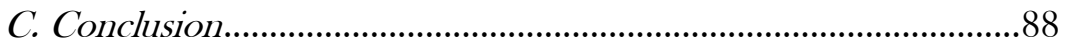

\section{THE AdOPTION OF THE FEDERAL CONSTITUTION AND BILl OF}

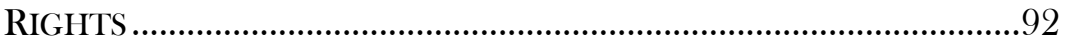

A. The Debate over the Constitution.................................................92

1. The Demand for a Bill of Rights ............................................92

2. The Ban on Religious Tests..................................................94

B. The Free Exercise Clause and the Bill of Rights ...........................97

VI. RELIGIOUS EXEMPTIONS FROM CIVIL LAWS.........................................101

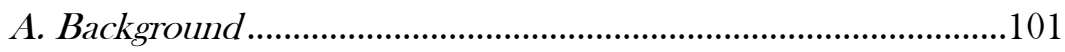

B. General Views on a Right to Religious Exemption During the

Founding Era... 
C. The Congressional Debates over Religious Exemption from Militia

Duty.

1. The Debate over the Bill of Rights.......................................110

2. The Debate over the Militia Bill of 1790-91 ...........................112

3. Conclusion.

D. Some Implications for Contemporary Free Exercise Doctrine..115

1. Religious Exemptions from Public Welfare Laws .................115

2. Clashes Between Religious Liberty and Civil Rights..............116

Religion, or the duty which we owe to our Creator, and the manner of discharging it, can be directed only by reason and conviction, not by force or violence; and, therefore, all men are equally entitled to the free exercise of religion, according to the dictates of conscience; and ... it is the mutual duty of all to practise Christian forbearance, love, and charity, towards each other.

- Virginia Declaration of Rights OF 1776, ART. $16^{1}$

\section{INTRODUCTION}

In contemporary America, no subject is more controversial than religious liberty and its relationship to other important values such as civil rights. This subject lies at the heart of recent cases such as Masterpiece Cakeshop, Ltd. v. Colorado Civil Rights Commission, in which the Supreme Court considered whether the Free Exercise Clause of the First Amendment ${ }^{3}$ should be interpreted to exempt businesses that have religious objections to same-sex

\footnotetext{
Va. Declaration of Rights of 1776, in 5 The Founders' Constitution, Bill of Rights, document 2, at 3 (Philip B. Kurland \& Ralph Lerner eds., 1987), http://presspubs.uchicago.edu/founders/documents/bill_of_rightss2.html [https://perma.cc/44P8-J77U] [hereinafter VA. DECLARATION OF RightS]. 
marriage from state civil rights laws that prohibit discrimination based on sexual orientation.

To shed light on the meaning of religious liberty and its place in our constitutional order, courts and scholars often seek to determine how that right was understood at the time of the founding. But this too turns out to be controversial. Although freedom of religion stands at the head of the Bill of Rights, discussions of that right during the ratification of the Constitution and the drafting of the First Amendment are sparse. ${ }^{4}$ For this reason, it is common to look to the earlier historical background. In particular, courts and scholars traditionally have focused on one of the most important debates over church and state in Revolutionary America: the dispute that took place during the mid-1780s over Patrick Henry's proposal to institute a tax for the support of Christian teaching and worship in Virginia. The opposition to this bill was led by James Madison, whose Memorial and Remonstrance Against Religious Assessments presented a forceful and wide-ranging defense of religious liberty. After defeating this bill, Madison and his allies secured the passage of Thomas Jefferson's Bill for Establishing Religious Freedom. The traditional account holds that this bill, like Madison's Memorial, was based on the Enlightenment view that individuals had a natural right to use their reason to pursue truth in the religious realm and that this realm lay beyond the legitimate scope of state authority, which was confined to such secular concerns as the protection of life, liberty, and property. A few years later, the same view led Madison to champion the adoption of the Free Exercise Clause as an essential part of the Bill of Rights. On this traditional account, the Clause should be understood to reflect the outlook of Madison and Jefferson. ${ }^{5}$ In recent decades, an increasing number of scholars have challenged this understanding of the Free Exercise Clause. $^{6}$ Although they agree that we can gain crucial insight from the debate in Virginia, they interpret that debate very differently. These

For an exploration of these debates, see infra Part V.B.

For classic examples of this account, see Everson v. Board of Educ., 330 U.S. 1, 11-13 (1947); Reynolds v. United States, 98 U.S. 145, 163-64 (1878).

6 See, e.g., Thomas E. Buckley, Church and State in Revolutionary Virginia, 1776-1787 (1977) [hereinafter Buckiey, Virginia]; JOHN A. RAgOSTA, WELLSPRING OF LibERTY: How Virginia's Religious Dissenters Helped Win the AMERICAN Revolution and SECuRED Religious Liberty 4-7 (2010); Michael W. McConnell, The Origins and Historical Understanding of Free Exercise of Religion, 103 HARV. L. REV. 1409, 1437-43 (1990). 
scholars observe that most of the political energy for the defeat of the Assessment Bill and the passage of Jefferson's statute came from Evangelical Christians who were motivated by religious principles. Evangelicals held that the exercise of state power in this area corrupted religion, usurped God's sovereign authority, interfered with the relationship between God and individual believers, and impeded the church's ability to spread the Gospel. ${ }^{7}$ On this revisionist account, the founding-era protections for religion should not be understood in terms of the Enlightenment principles of Jefferson and others, which these scholars characterize as secular, rationalist, and skepticalif not hostile-toward religion. ${ }^{8}$ Instead, those protections were adopted for essentially "religious reasons": to protect the freedom of individuals "to respond to God's will" and to enable the church to "fulfill its mission uncontaminated by civil government."

Other scholars emphasize that the protections for religious liberty reflected both Enlightenment and Evangelical ideals. ${ }^{10}$ Yet it is not always clear how the two different perspectives were related to each other.

In this Article, I propose a different way of understanding the intellectual foundations of the Free Exercise Clause and its state counterparts. The most basic view that supported religious liberty was neither secular rationalism nor Christian Evangelicalism, but what contemporaries called natural religion. As I shall show, natural religion-together with the associated ideas of natural law and natural rights-played a vital role in many areas of eighteenth-century thought, from political theory and jurisprudence to theology and science.

The concept of natural religion was based on a particular understanding of human beings and their relationship with God. According to this view, humans are inherently rational beings. Reason enables them to recognize that

See, e.g., BUCKLEY, Virginia, supra note 6, at 178-81.

See, e.g., id. at 4, 179-81; McConnell, supra note 6, at 1416, 1449-52.

BUCKLEY, VIRGINIA, supra note 6 , at 3,176, 180-81. For another insightful work that challenges the traditional account and argues that the origins of the Religion Clauses are better understood in terms of Christian principles, see Steven D. Smith, The Rise and Decline of American RELigious FreEdom (2014).

10 See, e.g., Mark DeWolfe Howe, The Garden and the Wilderness: Religion and Government in American Constitutional History (1965); Sidney E. Mead, The Lively EXPEriment: The Shaping OF ChristiantTy in America (1963); Nicholas P. Miller, The Religious Roots of the First Amendment: Dissenting Protestants and the Separation of Church and State (2012); John Witte, JR. \& Joel A. Nichols, Religion AND THE AMERICAN CONSTITUTIONAL EXPERIMENT ch. 2 (4th ed. 2016). 
they were created by a supreme being and that they should love, worship, and obey him. In addition to these duties to God, natural religion embraces the duties that one owes to oneself and to others. Taken together, these three kinds of duties constitute the law of nature.

The law of nature requires individuals to respect the inherent rights of other people-rights that arise from their own nature as rational creatures. Among the most important of those rights is religious liberty. Because reason is central to religion, individuals must be free to pursue spiritual truth and to worship in accord with their own consciences and understandings. As intelligent beings with the capacity for self-determination, they also are entitled to direct their own actions and to dispose of their persons and properties as they see fit. This is the basis of the natural rights to life, liberty, and property. Because these rights would be insecure in a state of nature, individuals would enter into civil society and establish a government with the force necessary to protect them. But force has no place in the realm of religion, which must be determined solely by reason and conscience. It follows that religious liberty is an inalienable right that is limited only by the inherent duty to respect the rights of other individuals and the community. In this way, the interlocking concepts of natural religion, natural law, and natural rights provided a powerful rationale for protecting freedom of conscience.

During the eighteenth century, the idea of natural religion took two different forms." The first was Deism. In its pure form, this view held that religion should be based on reason alone and therefore rejected all forms of religion that were based on a belief in divine revelation, including traditional Christianity. This version of natural religion, which was advocated by radicals like Thomas Paine, sparked intense discussion around the end of the eighteenth century, but it had a limited following in America before that time. ${ }^{12}$

Instead, the most common form of natural religion held that there was no necessary conflict between reason and revelation. This view maintained that the basic principles of religion and morality were founded in reason, but left open the possibility that God had chosen to reinforce those principles and disclose additional truths through revelation. This view had the potential to

See William Warren Sweet, Natural Religion and Religious Liberty in America, 25 J. RELIGION 45, 51 (1945).

12 See E. Brooks Holifield, Theology in America: Christian Thought From the Age of the Puritans to the Civil War 6-7, 159-72 (2003). 
establish common ground among people who held a wide variety of religious perspectives.

It was this form of natural religion that formed the basis for Jefferson's Bill for Establishing Religious Freedom. Although his private views were Deistic, his bill used the language of reason and natural rights in a way that appealed not only to Deists but also to many Christians. The same was true of Madison's Memorial. Nor were Jefferson and Madison the only ones who used such language: the ideas of natural rights and reason also appeared in several of the leading Evangelical petitions against Henry's Assessment Bill. ${ }^{13}$ In the end, that bill was rejected, and Jefferson's Bill adopted, by a political coalition of Evangelicals, rationalist Episcopalians, and Enlightenment liberals that was led by Madison.

In this way, the ideas of natural religion and natural rights were central to the struggle for religious liberty in Virginia. This is not to diminish the importance of Evangelical ideas, which also played a vital role. But to the extent that there was a consensus among the different groups that fought for religious freedom in that state, it was to be found in their support for Jefferson's Bill, with its affirmation that "the natural rights of mankind" included the inalienable freedom to use one's own mind to form and express religious opinions and to worship in accord with them. ${ }^{14}$ There is good reason to believe that the Free Exercise Clause was understood to reflect the same view-a view that was rooted in the concept of natural religion. ${ }^{15}$

See infra text accompanying notes 458-64 (discussing Presbyterian petition of August 13, 1785); infra text accompanying notes 522-24 (discussing Westmoreland County petition of November 2, 1784); infra note 531 (discussing General Baptist Association petition of August 13, 1785).

${ }^{14}$ Virginia, Act for Establishing Religious Freedom, in 5 The Founders' CONSTITUTION, supra note 1, Amendment I (Religion), document 44, http://presspubs.uchicago.edu/founders/documents/amendI_religions44.html [https://perma.cc/7D6E-4N38] [hereinafter Virginia Act].

${ }_{15}$ In the legal literature, most discussions of rational religion during the founding period focus on Deism. See, e.g., William P. Marshall, The Case Against the Constitutionally Compelled Free Exercise Exemption, 40 CASE W. RES. L. REv. 357, 377 (1989-90) (asserting that "the governing intellectual climate of the late eighteenth century was that of deism, or natural law"); Noah Feldman, The Intellectual Origins of the Establishment Clause, 77 N.Y.U. L. REv. 346, 391-93 (2002). Among the few law review articles to discuss "natural religion" in the broader sense is Steven D. Smith, The Rise and Fall of Religious Freedom in Constitutional Discourse, 140 U. PA. L. REv. 149, 158-62, 193-96 (1991). Other thoughtful explorations of rational religion during this period include Kathleen A. Brady, Fostering Harmony Among the Justices: How Contemporary Debates in 
This Article proceeds in six Parts. The first two demonstrate that natural religion and its related ideas of natural law and natural rights held a central place in the intellectual world of eighteenth-century Americans and were integrally connected with their understanding of religious liberty. Part I highlights the role that these ideas played in the works of John Locke, the philosopher who had the deepest impact on America. Part II shows that these ideas also were essential to many other forms of thought during this period, including leading treatises on the law of nature and nations; the English jurisprudence of Blackstone and Mansfield; the moral philosophies of British rationalism and the Scottish Enlightenment; Deist and Christian theology; and even Newtonian natural science. All these strands of thought came together in the Radical Whig ideology that shaped the political consciousness of colonial Americans. Part III shows how natural religion and its cognate ideas provided the justification for the American Revolution and were enshrined in the first state constitutions and declarations of rights. Part IV explains the vital part that these ideas played in the struggle over religious liberty in mid-1780s Virginia. Part V discusses the light they can shed on the founding-era debates over the protections for religious freedom in the Constitution and the Bill of Rights.

Finally, in Part VI, I explore what this history can tell us about the problem of religious exemptions from civil laws. Contrary to the position taken by revisionist scholars, there is no persuasive evidence that eighteenth-century Americans espoused a general principle that individuals were entitled to

Theology Can Help to Reconcile the Divisions on the Court Regarding Religious Expression by the State, 75 NOTRE DAME L. REv. 433, 440-477 (1999), and Laura Underkuffler-Freund, The Separation of the Religious and the Secular: A Foundational Challenge to First Amendment Theory, 36 WM. \& MARY L. Rev. 837, 874-960 (1995). For valuable discussions of eighteenth-century natural religion by historians, political scientists, and philosophers, see PETER BYRNE, NATURAL Religion and the Nature of Religion: The Legacy of Deism chs. 1-5 (Routledge 2013) (1989); Michael J. Lee, The Erosion of Biblical Certainty: Battles over Authority AND INTERPRETATION IN AMERICA chs. 1-3 (2013); HeNry F. MAY, THE ENLIGHTENMENT IN America (1976); Miller, supra note 10; Claude M. Newlin, Philosophy and Religion in Colonial America ch. 7 (1962; Protestantism and the American Founding (Thomas S. Engeman \& Michael P. Zuckert eds., 2004); Michael P. Zuckert, The NATURAl Rights RePublic: STUdies in the Foundation OF the American Political Tradition (1997); B. A. Gerrish, Natural and Revealed Religion, in 2 The Cambridge History of EighteenthCentury Philosophy 641, 648-60 (Knud Haakonssen ed., 2000); Sweet, supra note 11. 
exemptions from laws that regulated conduct in a way that conflicted with their religious beliefs. As a non-originalist, I do not believe that this history necessarily should be controlling. It is an open question whether the Supreme Court should overrule Employment Division v. Smith ${ }^{16}$ and subject such laws to some form of heightened review. The Court is currently considering this question in Fulton v. City of Philadelphia, ${ }^{17}$ a free exercise challenge to a city's decision to terminate its foster-care contract with a Catholic social service agency which refused on religious grounds to vet same-sex couples to serve as foster parents. However, if the Court decides to adopt heightened scrutiny for general laws that burden religious exercise, it ought not to employ this approach to curtail the application of civil rights laws, such as the ones involved in Fulton and Masterpiece Cakeshop. Instead, as I shall show, one of the most important lessons that emerges from the history is that the right to religious liberty does not take precedence over the civil rights of other people.

\section{JOHN LOCKE ON RELIGION, TOLERATION, AND THE RELATIONSHIP BETWEEN CHURCH AND STATE}

\section{A. Locke on Natural Religion}

\section{The Concept of Natural Religion}

Locke's religious, moral, and political theory is founded on the notion that human beings are rational creatures. ${ }^{18}$ Because they are endowed with reason, individuals are free, self-determining beings who are capable of directing their own thoughts and actions and pursuing their own happiness or good. ${ }^{19}$ To know what that good is, they must pursue knowledge about themselves and the world.

494 U.S. 872 (1990).

922 F.3d 140 (3d Cir. 2019), cert. granted, 140 S. Ct. 1104 (Feb. 24, 2020) (No. 19-123).

For a fuller exploration of Locke's views on religion and toleration, see Steven J. Heyman, The Light of Nature: John Locke, Natural Rights, and the Origins of American Religious Liberty, 101 MarqueTte L. Rev. 705 (2018) [hereinafter Heyman, Light of Nature].

19 See John LOCKe, An ESSaY CONCERning Human Understanding bk. II, ch. XXI, \$\$ 1-73, at 233-87 (Peter H. Nidditch ed., Oxford Univ. Press 1975) (1689) [hereinafter Locke, Human UNDERSTANDING]. 
Locke explores the foundations of that knowledge in An Essay Concerning Human Understanding, one of the landmark philosophical works of the Enlightenment. According to Locke, most of our knowledge is quite limited because it is derived from sense experience..$^{20}$ But there are two key exceptions to this generalization. First, following Descartes, Locke holds that we have intuitive knowledge of our own existence. ${ }^{21}$ And second, he maintains that we are capable of knowing some truths through deductive reason. ${ }^{22}$ The most important of these truths concern our relationship with God. They form the basis of "Natural Religion," or religion insofar as it can be known through reason. ${ }^{23}$

The first principle of natural religion is that God exists. ${ }^{24}$ In the Essay, Locke presents two arguments for this proposition. First, in a version of the traditional cosmological argument, he contends that all beings can be traced to a first cause that must have existed from eternity, and that is the source of all the qualities they have. ${ }^{25}$ Because we are aware of our own existence as "knowing intelligent Being[s]," we can conclude that we ultimately must have received our existence and intelligence from another being that is "eternal, most powerful, and most knowing." ${ }^{26}$ This is what we "call GOD." ${ }^{27}$ Second, Locke offers a version of the traditional argument from design: that only an intelligent being could have "produce[d] that order, harmony, and beauty which is to be found in Nature." ${ }^{28}$

A second truth of natural religion concerns the relationship between people and God. Because humans are "Inferior [and] Finite" beings, who are created by and dependent upon another being who is infinite, "omnipotent, perfectly wise and good," they have a duty "to honour, fear, and obey GOD." ${ }^{29}$

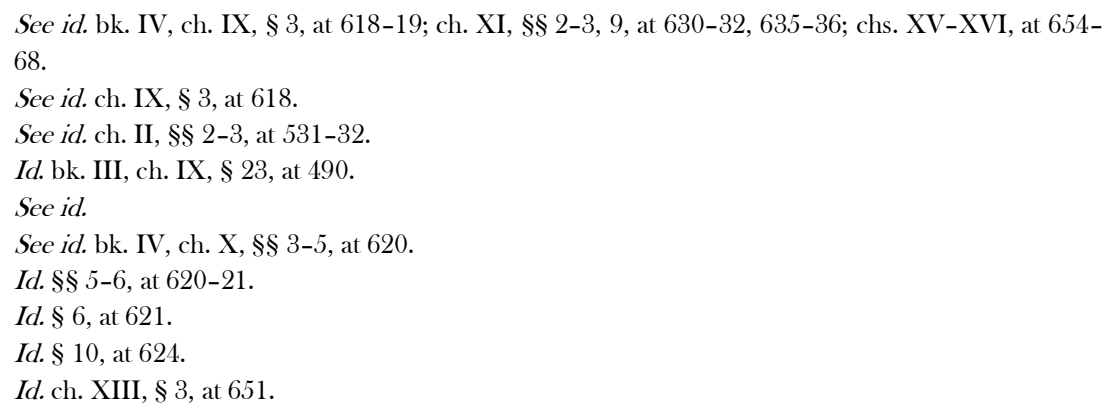


Third, reason enables individuals to discern the moral rules that God has established to govern their conduct. These rules, which Locke calls "the Law of Nature and Reason," are rooted in our nature as "rational Creatures." ${ }^{30}$ In the Essay, Locke suggests that by reflecting upon the nature of God and human beings and the relationship between them, reason is capable of developing morality into a demonstrative science that has the same logical rigor as mathematics. ${ }^{31}$

Although Locke never attempted to fully work out the content of natural law, his writings contain important indications of what it includes. Following the Christian natural law tradition, he makes a three-fold division between the duties that one owes to God, to oneself, and to others. ${ }^{32}$ The first category of duties requires individuals not only to "obey" but also to "honour" and "worship [l" God. ${ }^{33}$ The second category embraces an obligation to preserve oneself and not to take one's own life or to expose it to the arbitrary power of others. $^{34}$

Locke's Second Treatise of Government contains an important discussion of the law of nature as it applies to the third category-duties to others. As rational, self-determining beings, individuals are naturally free "to order their Actions, and dispose of their Possessions, and Persons as they see fit." ${ }^{35}$ In other words, they have natural rights to life, liberty, and property. This natural state of freedom is also a state of equality, in which no one is inherently superior or subordinate to anyone else. ${ }^{36}$ Locke then uses these ideas to establish the duties that individuals owe one another: the law of nature holds

30 John Locke, Two Treatises of GOvernment bk. II, $\$ \$ 96,124$, at 332, 351 (Peter Laslett ed., Cambridge Univ. Press 1988) (student ed. 1988) (3d ed. 1698) [hereinafter Locke, GOVERNMENT]. See Locke, Human UNDERSTANDing, supra note 19, bk. IV, ch. III, $\$ 18$, at 549.

32 See John Locke, Questions Concerning the Law of Nature 167-69 (Robert Horwitz, Jenny Strauss Clay, \& Diskin Clay eds. \& trans., Cornell Univ. Press 1990). As the editors explain, this work was composed in Latin "no later than 1664" and was first published, with an English translation, in 1954. Id. at 29-31.

33 LOCKE, HuMAN UNDERSTANDING, supra note 19, bk. I, ch. IV, § 7, at 87; bk. IV, ch. XIII, § 3, at 651.

34 See, e.g., LOCKE, GOVERNMENT, supra note 30, bk. II, \$§ 6, 23-24, 135, at 270-71, 283-85, 357.

${ }_{35} \quad I d . \$ 4$, at 269.

${ }^{36}$ See id. 
that because everyone is "equal and independent, no one ought to harm another in his Life, Health, Liberty, or Possessions."

For Locke, the three propositions we have just discussed-that God exists, that people have a duty to worship and obey him, and that he has prescribed a law for them to follow-make up the substance of "Natural Religion." ${ }^{88}$ Natural religion lies at the heart of all reasonable religion. In contrast to ancient texts that may be difficult to interpret and that may generate sectarian controversy, "the Precepts of Natural Religion are plain, and very intelligible to all Mankind" by the "light of Reason." worship" of God lies not in elaborate "ceremonies and outward performances," but rather in "a good life" that is characterized by piety toward God and virtue in relation to oneself and others. ${ }^{40}$ Such a life is not only pleasing to God but also promotes the wellbeing of the society and its members." Moreover, because the principles of natural religion can be discerned by "the common light of nature," they are matters that the adherents of different religions can agree upon. ${ }^{42}$ For all these reasons, Locke maintains that natural religion should have a central place in religious life. ${ }^{43}$

\section{The Limits of Natural Religion and the Need for Revealed Religion}

At the same time, Locke concedes that some matters are beyond the scope of human reason and natural religion. With regard to worship, for example, while reason teaches that one should approach God with "a pure heart," there is no way to know what "outward modes of worship" he desires other than

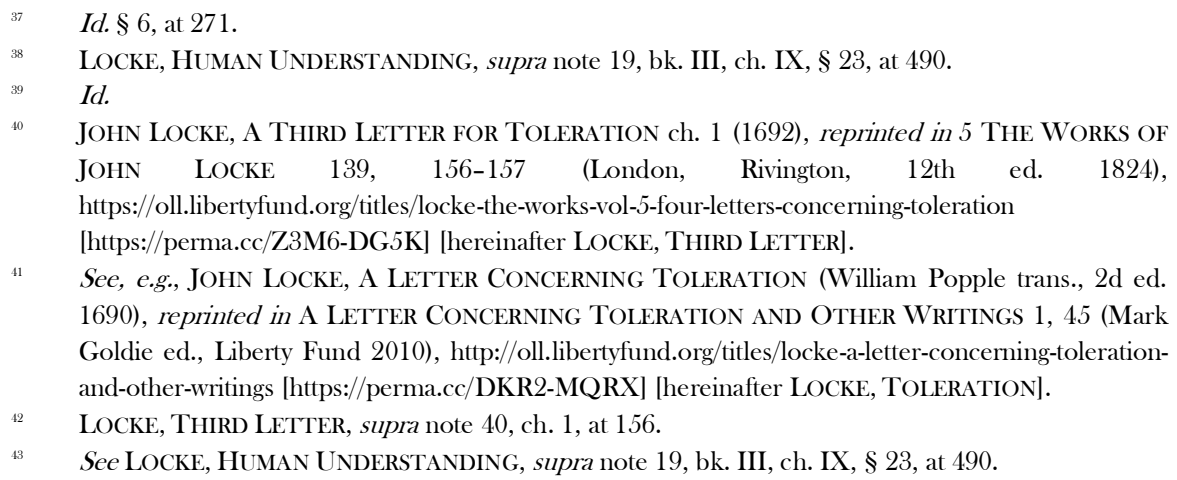


through divine revelation. ${ }^{4}$ Likewise, because Locke holds that human knowledge can come only from ideas derived from sensation and from reflection upon those ideas, reason can tell people nothing about the spiritual world (other than the existence and attributes of God), which again can be known only through revelation. ${ }^{45}$

The most significant limitation on the scope of reason has to do with what can be known about an afterlife, a subject that is crucial to Locke's view of religion and morality. Locke maintains that, as rational creatures, individuals are impelled to pursue their own good. ${ }^{46}$ Although the interests of different people do not inherently conflict with one another, there are situations in which they do. In such cases, it may be rational for one person to pursue her own good by inflicting harm on another. The law of nature is meant to restrain such conduct. But laws are useless if they are not backed by sanctions. ${ }^{47}$ It is evident that those who violate natural law are not always punished in this life. ${ }^{48}$ It follows that if that law is to be effective, it must be enforced in a future state where individuals will be requited for their deeds in this world. ${ }^{49}$ In the Essay, Locke offers some grounds to believe that such a future state exists, but he does not contend that its existence actually can be demonstrated by reason. ${ }^{50}$ This poses a serious problem for his whole account of morality and religion.

Difficulties like these lead Locke to conclude that human life must be directed not only by natural religion, which is based on reason, but also by revealed religion, which is based on faith..$^{51}$ In the Essay, Locke defines faith as assent to a proposition not because it has been "made out by the Deductions of Reason," but rather because one trusts in the veracity of God, who has revealed that proposition to human beings. ${ }^{52}$

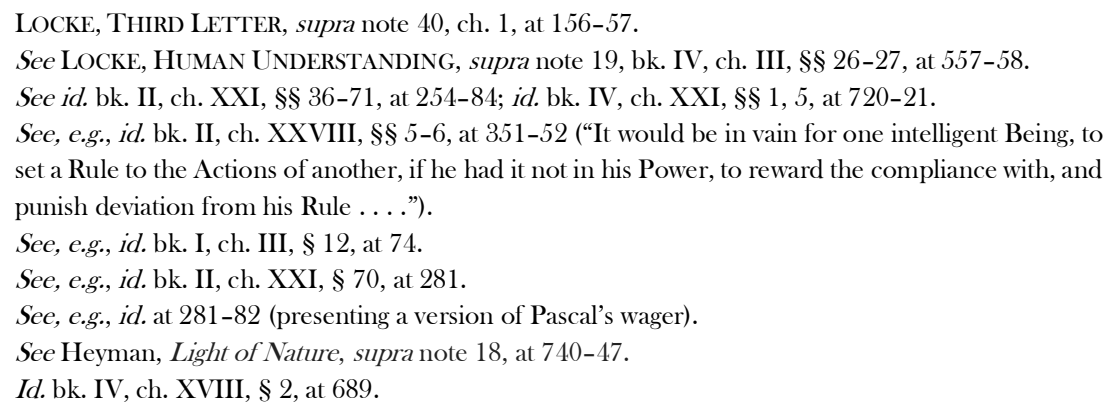


When Locke speaks of revelation, he is thinking primarily of the Bible and especially the New Testament. That revelation makes clear that there is a future state in which human beings will be rewarded or punished under the law of nature for their conduct on earth. ${ }^{53}$ In this way, revealed religion is able to overcome the difficulty encountered by natural religion, which is incapable of demonstrating the existence of a future state upon which morality ultimately depends.

\section{The Relationship Between Faith and Reason}

For Locke, however, this does not mean that faith and revelation supersede reason and natural religion. Instead, he insists that even with regard to revelation, reason plays an essential role. To begin with, one must use reason to decide whether something should be regarded as a divine revelation in the first place. ${ }^{54}$ In the case of the New Testament, Locke maintains that its authenticity is attested by the miracles that Jesus performed. ${ }^{55}$

According to Locke, we must also use our reason to assess the content of a purported revelation. In this connection, he draws a key distinction between propositions that are (1) “According to Reason," (2) “Above Reason," and (3) "Contrary to Reason." ${ }^{36}$ Although revelation can teach the first sort of truths (such as the idea that God exists), it is not requisite for the knowledge of such truths because they can be demonstrated by reason. ${ }^{57}$ Instead, the principal function of revelation is to disclose truths that are "above Reason," such as the existence of a future state..$^{58}$ This is the legitimate province " of Faith."

By contrast, Locke insists that revelation can never teach truths that are "Contrary to Reason," in the sense that they conflict with the clear knowledge that we attain either directly or "by evident deductions of Reason"-a term that

See, e.g., John locke, The Reasonableness of Christianity as Delivered in the SCRIPTURES ch. XIV, at 154, 162-63 (John C. Higgins-Biddle ed., Clarendon Press 2000) (1695) [hereinafter LOCKE, REASONABLENESS].

See Locke, Human Understanding, supra note 19, bk. IV, ch. XVIII, \$\$ 6, 8, 10, at 693-695.

See LOCKe, Reasonableness, supra note 53, ch. XIV, at 142-43, 146-47, 153.

See LOCKe, Human Understanding, supra note 19, bk. IV, ch. XVII, §23, at 687.

See id. bk. IV, ch. XVIII, $\$ \$ 4-5$, at 690-91.

Id. $\$ 7$, at 694 .

Id 
appears to include the law of nature. ${ }^{60}$ As rational beings, we cannot accept as divine revelation anything that conflicts with reason, because we can never have more confidence that it truly is a revelation than we have in our own rational faculties, which are "the most excellent Part" of the nature that God has bestowed upon us. ${ }^{61}$ By the same token, we must interpret the words of a revelation so that it does not conflict with reason. ${ }^{62}$ Thus, even in determining the authenticity and meaning of revelation, "Reasonmust be our last Judge and Guide in every Thing." ${ }^{, 63}$

On these grounds, Locke rejects what he takes to be the common view that faith and reason are opposed to one another. Properly understood, faith is "nothing else but an Assent founded on the highest Reason." Rather than undermining reason, faith "assist[s] and improve[s]" it by giving us "new Discoveries of Truth, coming from [God, who is] the Eternal Fountain of all Knowledge. ${ }^{65}$ On this view faith and reason are complementary, as are the forms of religion that arise from them. Natural religion lays the foundations of religion by teaching human beings everything that can be known about God and morality through reason. Revealed religion builds on these foundations and completes the edifice that natural religion began. ${ }^{66}$

Id. $\$ 5$, at $691-93$.

Id. at $692-93$.

See id.; id. \$ 8, at 694-695.

Id. ch. XIX, § 14 , at 704 .

Id. ch. XVI, § 14 , at 668 .

Id. ch. XVIII, § 10, at 695 .

In contrast to the Essay, which sharply criticized those traditionalists who elevated faith above reason, Locke's Reasonableness of Christianity was directed against Deists who sought to base religion on reason alone. See, e.g., LOCKe, REASONABLENESS, supra note 53, ch. I, at 5 \& n.2. The work therefore lays more stress than the Essay on the limits of natural reason and the need for revelation. Although reason is sufficient to understand the part of natural law that is needed to govern external interaction between individuals and to ensure the peace and prosperity of civil society (which is the part of natural law that Locke focuses on in the Essay and the Two Treatises), reason has not led people to comprehend the full range of that law, which also requires individuals to be inwardly virtuous and to treat one another with charity and good will. See id. ch. IX, at 58; ch. XII, at 12223; ch. XIV, at 147-55. This leads Locke to make the paradoxical remark that "Natural Reason" seems to be incapable of establishing "Natural Religion in its full extent." Id.ch. XIV, at 148. Instead, he maintains that our first full and clear knowledge of the moral law came from revelation. See id. at $149,155-57$. When we consider the teachings of that law, however, we immediately recognize that they are "agreeable" and "conformable" to reason. Id. at 149, 151, 153, 156, 159. The law revealed in the Gospels is substantially the same as the law of nature and reason. See id. ch. II, at 


\section{B. Locke on Religious Liberty and the Separation of Church and State}

\section{Religious Liberty}

Let us now turn to the role that reason plays in Locke's defense of religious freedom. His most comprehensive discussion appears in A Letter Concerning Toleration (1689). ${ }^{67}$ The Letter begins by advocating for religious toleration in specifically Christian terms. ${ }^{68}$ True Christianity is concerned not with "the Pomp of ... Outward Worship" nor with disputes over doctrinal purity but with "the regulating of Mens Lives according to the Rules of Vertue and Piety. ${ }^{{ }^{9}}$ Instead of seeking "Ecclesiastical Dominion" over other people or forcing them to embrace a particular form of worship or belief, Christians are called to show "Charity, Meekness, and Good-will in general towards all Mankind; even to those that are not Christians." ${ }^{\text {,0 }}$

For these reasons, Locke maintains that "Toleration [is] the chief Characteristical Mark of the True Church." "1 As he soon makes clear, however, his goal is to show that toleration is required not only by "the Gospel

13-14; id. ch. III, at 19-21; id. ch. XIV, at 159. On this view, revelation does not supplant or invalidate natural religion, but instead leads human beings to a clear and comprehensive knowledge of it. Moreover, while the Reasonableness stresses the advantages of Christianity for salvation, see id. ch. XIV, at 140-64, it also suggests that, at least in some circumstances, salvation can be attained through natural religion alone, see id. ch. XIV, at 139-40; Heyman, Light of Nature, supra note 18, at 767-69. In short, while the Essay and the Reasonableness engage with different opponents and approach the relationship between faith and reason from different angles-the former from a naturalistic standpoint and the latter from the perspective of Christian theology--the two works converge on a view that affirms the essential harmony of natural and revealed religion.

67 The Letter was published in Latin in April 1689. See Mark Goldie, Notes on the Texts in Locke, TOleration, supra note 41, at xxix. That fall saw the publication of an English translation by Locke's friend William Popple, which was made with the author's knowledge but without his involvement. See id. at xxix-xxx. In this Article, I quote from Popple's translation, which is the one that has been used in the English-speaking world from Locke's day to our own. For a more recent and literal translation, see JoHn LOCKe, A LeTter CONCERning TOLERATION (Michael Silverthorne trans. 2010) (1689), in LOCKE ON TOLERATion 3 (Richard Vernon ed., Cambridge Univ. Press 2010).

68 See LoCKe, TOLERATION, supra note 41 , at 7-11.

69. Id. at 7-8.

70 Id.

71 Id. at 7. For some readings of Locke's argument that emphasize its Christian dimension, see MILLER, supra note 10, at 75-79; SMITH, supra note 9, at 39-40. 
of Jesus Christ" but also by "the genuine Reason of Mankind." ${ }^{\text {,2 }}$ In other words, his argument is founded upon reason and natural religion as well as upon revelation. As with the Two Treatises of Government, it is the fusion of these two modes of discourse that gives Locke's Letter Concerning Toleration the unique power it had for eighteenth-century British and American readers.

The Letter's argument begins with the premise that human beings are inherently free. The philosophical rationale for this premise may be found in the Two Treatises and the Essay. In those works, Locke argues that our freedom is grounded in our capacity for reason, which enables us to think for ourselves, to direct our own actions, and to pursue well-being. ${ }^{73}$

In the Letter, Locke takes this conception of inherent human liberty for granted. In addition, he distinguishes two sorts of well-being that humans are concerned with: their temporal happiness and their happiness in the world to come. ${ }^{74}$ To support their life in this world, individuals need to acquire external goods through labor. ${ }^{75}$ But their possession of these goods is vulnerable to fraud and violence by others. ${ }^{76}$ As in the Second Treatise, the solution lies in the social contract. ${ }^{77}$ To protect their properties as well as their lives and liberties, individuals would agree to form a civil society and to entrust the rulers with the force necessary to prevent individual wrongdoing and foreign aggression. $^{78}$ To secure this protection, individuals would agree to give up some of their freedom of outward conduct and to follow the laws adopted by the society. ${ }^{79}$

By contrast, Locke insists that when individuals enter the social contract, they would not give up their liberty to form their own religious beliefs or to worship God in the manner they believe is required to attain eternal happiness and salvation. ${ }^{80}$ In the Letter, he offers four arguments for this proposition.

LOCKE, TOLERATION, supra note 41 , at 11.

See supra text accompanying notes 18-19, 35 .

See LOCKe, TOLERATION, supra note 41 , at 45-48.

See id. at 46.

See id. at 46-47.

For Locke's account of the social contract in the Second Treatise, see Locke, Government, supra note 30 , bk. II, $\$ \$ 87-89,95,99$.

See LOCKe, TOLERATION, supra note 41 , at 46-47.

See id. at 33-35, 46-48.

See id. at 12-15, 45-46. 
First, he contends that religious liberty is inalienable in the sense that individuals cannot relinquish it when they enter society:

[N]o man can so far abandon the care of his own Salvation, as blindly to leave it to the choice of any other, whether Prince or Subject, to prescribe to him what Faith or Worship he shall embrace. For no Man can, if he would, conform his Faith to the Dictates, of another. All the Life and Power of true Religion consists in the inward and full perswasion of the mind: And Faith is not Faith without believing. ${ }^{81}$

As this passage indicates, Locke's defense of religious liberty rests on the same understanding of religion that we explored earlier-an understanding that seeks to harmonize faith and reason. In maintaining that "Salvation" depends upon "Faith," he invokes a doctrine that is central to Christianity and especially to Protestantism. At the same time, his assertion that "All the Life and Power of true Religion consists in the inward and full perswasion of the mind" makes clear that he sees religious belief as an exercise of our intellectual faculties.

The same is true of the other arguments that Locke advances for religious liberty. His second contention is that "[t]he care of souls cannot belong to the Civil Magistrate, because his Power consists only in outward force: But true and saving Religion consists in the inward perswasion of the Mind; without which nothing can be acceptable to God." ${ }^{\text {2 }}$ Outward force has no power to convince "the Understanding.." ${ }^{{ }_{3}}$ To be sure, the magistrate has the same right that everyone has to "draw [others] into the way of Truth" by means of "Arguments." But he may not use penalties for this purpose, for "[i]t is only Light and Evidence that can work a change in Mens Opinions." ${ }^{85}$ In short, religion should be a matter not of coercion but of "reason, and conviction."

Third, Locke argues that even if coercion were capable of changing people's minds, this would do nothing to promote the salvation of souls, because rulers have no privileged access to religious truth. The interests of true religion would only be harmed if subjects were compelled "to quit the

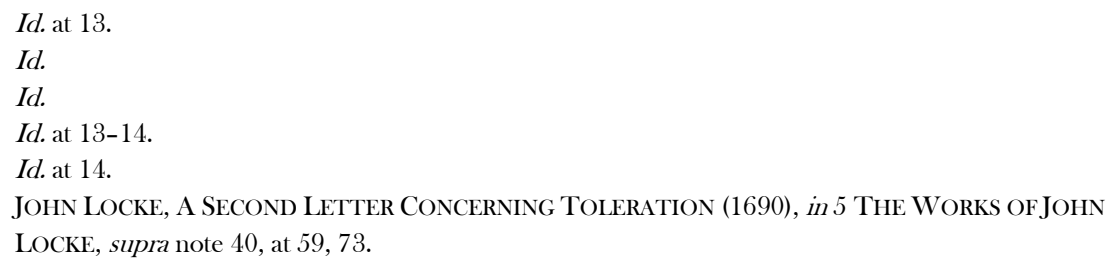


Light of their own Reason; to oppose the Dictates of their own Consciences; and blindly to resign up themselves to the Will of their Governors" in such matters. ${ }^{87}$ Finally, there is no call for individuals to give up their religious liberty when they enter society because the beliefs and forms of worship they embrace do not injure others or violate their rights. ${ }^{88}$ It follows that, in matters of religion, "[e]very man ... has the supreme and absolute Authority of judging for himself."

\section{Separation of Church and State}

For all these reasons, Locke maintains that when individuals enter civil society, they would fully retain their liberty of religious belief and worship and would grant the society and government no power whatever in this area. This brings us to another distinctive feature of Locke's view-his argument for a strict separation of church and state. On this view, the state is a community that is concerned solely with its members' temporal welfare, an interest that it promotes by securing their "natural" and "civil rights" to life, liberty, and property." The state has no power to either impose or forbid particular beliefs or modes of worship. ${ }^{91}$ These matters lie purely within the province of the "Religious Societies" or "Churches" that individuals voluntarily form to promote their own salvation. ${ }^{92}$ Conversely, a church is properly concerned only with spiritual matters and may not exercise temporal power over individuals, regardless of whether they belong to its communion. ${ }^{93}$

\section{The Limits of Religious Liberty and Toleration}

As the previous section indicates, Locke understands religious liberty in jurisdictional terms. ${ }^{94}$ Religious belief and practice are matters to be decided solely by individuals and the religious societies they voluntarily form, and the

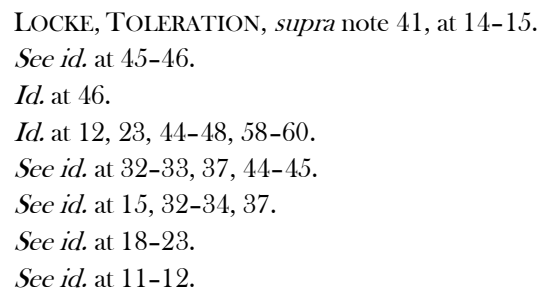


state has no authority to meddle in such affairs. By the same token, however, churches and believers cannot legitimately invoke religion as a basis for depriving individuals of civil rights such as life, liberty, or property, for these rights fall within the province and protection of the political community. ${ }^{95}$ This limitation on the scope of religious conduct arises from the fundamental division between religion and state that results from Locke's theory of natural law and the social contract.

This theory also imposes another important limitation on religious liberty. Locke defends this liberty on the ground that religion involves a relationship between individuals as rational creatures and God. ${ }^{96}$ The law of nature and reason protects this relationship against interference by other individuals, churches, or the state. ${ }^{97}$ But just as that law grants individuals a right to religious liberty, it forbids them to use that liberty in a way that violates the natural rights of others (for example, by performing rituals involving child sacrifice). ${ }^{98}$ In these two ways-by separating the spheres of state and religion and by grounding religion in reason-Locke uses the theory of natural religion to establish the foundations and the limits of religious liberty.

Finally, Locke also employs that theory to argue that some religious beliefs are not entitled to toleration at all. To begin with, this is true of religions whose adherents claim the right to dominate or impose their own beliefs on other people. ${ }^{99}$ Because beliefs of this sort deny the equal status and rights of others, they are "contrary to human Society, or to those moral Rules which are necessary to the preservation of Civil Society." ${ }^{100}$ Locke also would deny toleration to atheists on the ground that they reject even the natural religion which he regards as the foundation of morality, including the obligation to keep the promises upon which the social contract is based..$^{101}$ On the other hand, he makes clear that religious liberty extends to everyone who recognizes

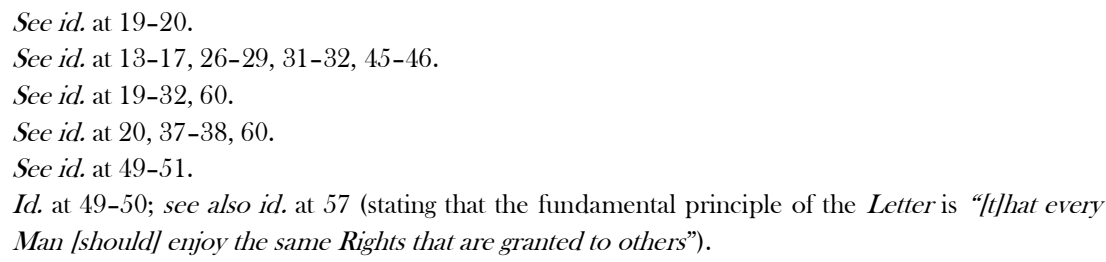


"the Being of a God," including Jews, Muslims, and pagans ${ }^{102}$-a clear indication that on his view religious freedom is not based simply on the liberty that Christians enjoy under the Gospel, ${ }^{103}$ but also is founded on nature and reason. In short, for Locke, "Liberty of Conscience is every mans natural Right." ${ }^{104}$

\section{Conclusion}

In the political, philosophical, and theological works we have explored, Locke places reason at the heart of religion. According to Locke, reason shows human beings that God exists, that they have a duty to worship and obey him, and that he has given them the law of nature to guide their conduct. In addition to establishing these principles of natural religion, reason points to the need for faith and revelation, which reinforce and perfect those principles. Reason also provides a justification for religious liberty. As rational beings, individuals have both a right and a duty to use their minds to seek the truth concerning God and what he requires them to believe and to do to attain salvation. At the same time, reason defines the limits of religious liberty, which cannot properly be invoked as a justification for denying the equal status and rights of others.

\section{NATURAL RELIGION IN EIGHTEENTH-CENTURY THOUghT}

Although Locke's view of natural religion and freedom of conscience had a deep impact on eighteenth-century Americans, ${ }^{105}$ his view was far from alone.

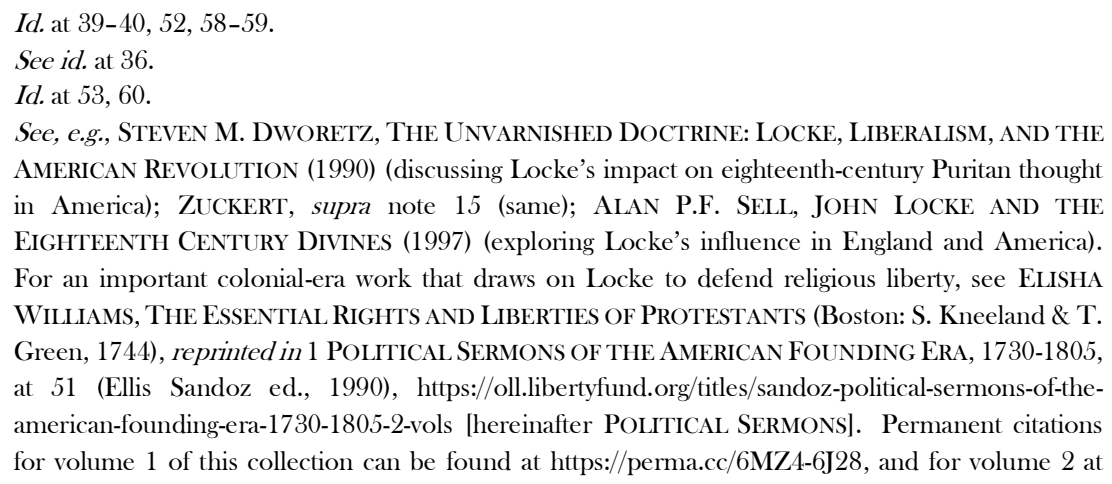


Those concepts were central features of the intellectual world they inhabited. This Part surveys the role that those ideas played in a wide range of fields, including natural jurisprudence, English law, moral philosophy, theology, natural science, and the Whig ideology that informed the American Revolution.

\section{A. The Law of Nature and Nations}

Although Locke employed the idea of natural law in a powerful way, he did not offer a systematic account of its content. For that, eighteenth-century Americans looked to writers on the law of nature and nations such as Hugo Grotius, Samuel Pufendorf, Jean-Jacques Burlamaqui, and Emer de Vattelauthors who were frequently invoked in the political discourse of this period. ${ }^{106}$

A leading exposition of natural law could be found in the works of Pufendorf, which were an important source for Locke's own thought on the subject. ${ }^{107}$ Pufendorf's magisterial treatise on The Law of Nature and Nations appeared in 1672. ${ }^{108}$ The following year, he published an abridgment for students and the public which was soon translated into English as The Whole Duty of Man, According to the Law of Nature.109

Pufendorf's account of natural law will seem largely familiar to anyone who has read Locke's Two Treatises. Individuals are rational beings who are naturally accountable to no one but God. ${ }^{110}$ The state of nature is a condition

https://perma.cc/9FCF-8ULX. For discussions of Williams, see MiLLER, supra note 10, at 94-101; ZUCKERT, supra note 15, at 183-93.

106 See Bernard Bailyn, The Ideological Origins of the American Revolution 27 (enlarged ed. 1992).

107 See John Marshall, John LOCKe 201-04 (1994). (discussing Locke's complex relationship with Pufendorf's thought).

108 Samuel Pufendorf, Of The Law OF NATURe And Nations (photo reprt.) (London, J. Walthoe et al. eds., Basil Kennett trans., 4th ed. 1729), https://hdl.handle.net/2027/osu.32437121669218 [hereinafter PUFENDORF, LAW OF NATURE].

109 Samuel Pufendorf, The Whole Duty of Man, According to the LaW of Nature (Ian Hunter \& David Saunders eds., Andrew Tooke trans. 1691, Liberty Fund 2003) (1673), https://oll.libertyfund.org/titles/pufendorf-the-whole-duty-of-man-according-to-the-law-of-nature1673-2003 [https://perma.cc/U7S6-E2NY] [hereinafter PUFENDORF, DUTY]. For a more recent and literal translation, see SAMuel Pufendorf, On the Duty of MAN ANd Citizen ACCording TO Natural LaW (James Tully ed., Michael Silverthorne trans., Cambridge Univ. Press 1991) (1673).

110 See PUfendorf, DuTY, supra note 109, bk. II, ch. I, § VIII, at 169-70. 
of natural liberty and equality, in which individuals are free to direct their own actions within the law of nature and reason. ${ }^{111}$ Because they would be in danger of violence in a state of nature, they would agree to form a civil society and to establish government for mutual security. ${ }^{112}$

Like Locke, Pufendorf holds that the law of nature is established by God and knowable by "the Light of Reason." "13 That law specifies the duties that one owes to God, to oneself, and to others. ${ }^{114}$ The first category, or "[t]he Duty of Man towards God, so far as can be discover'd by Natural Reason," is what Pufendorf calls "Natural Religion." ${ }^{15}$ The chapter that he devotes to this subject in Whole Duty of Man is the fullest account that can be found in contemporary works on the law of nature and nations. ${ }^{116}$

As Pufendorf explains, the duties of natural religion can be divided into two parts. The "Theoretical" part obliges individuals to use reason to form true ideas about God. ${ }^{117}$ These ideas are that God exists, that he created the universe, that he "governs the whole World, and particularly Mankind," and that he is infinite in perfection. ${ }^{118}$

Pufendorf then turns to "[t]he Propositions of Practical Natural Religion," which concern the internal and external worship that human beings should render to God. ${ }^{119}$ Internal worship consists of regarding him with love, reverence, and honor, while external worship involves public and private prayer as well as doing one's best to obey his commands. ${ }^{120}$

For Pufendorf, natural religion is an essential part of natural law theory not only because it determines the inherent duties that people owe to God, but also because religion is essential to social order. ${ }^{121}$ The fear of God is necessary

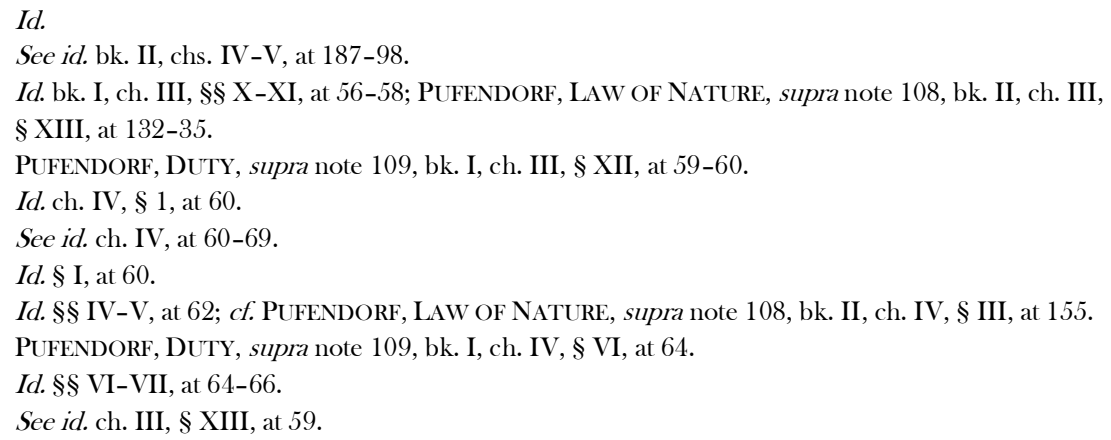


to restrain the unruly passions and conduct of individuals, which cannot effectively be controlled merely by temporal punishments or a sense of moral duty. ${ }^{122}$ For this reason, religion is properly regarded as "the utmost and firmest Bond of Human Society."123

In a later work, Of the Nature and Qualification of Religion in Reference to Civil Society (1687), ${ }^{124}$ Pufendorf brings his natural law theory to bear on the problems of religious toleration and church-state relations. ${ }^{125}$ Like Locke, he argues that, as "Rational Creatures," human beings are inherently free to worship God in accord with their "own Opinion[s]" as informed by reason or revelation. ${ }^{126}$ Individuals would not surrender this freedom when they submit to civil government, which is established not "for Religions sake" but for the security "of their Liberty, Life, and Fortunes."

Despite what initially appears to be a strong defense of religious liberty and church-state separation, Pufendorf contends that sovereigns possess substantial authority with regard to religion. Because religion is essential to social order, they not only should take care to promote natural religion among their subjects, but they may also prohibit actions that subvert natural religion, such as public idolatry, blasphemy, and denial of God's existence. ${ }^{128}$

Pufendorf goes considerably further when discussing the authority of sovereigns in modern European states. To maintain public peace and tranquility, it is desirable that there be "but one Faith and Religion in a State," especially if it is the true religion of Christ as "contained in the Holy Scripture." ${ }^{129}$ Accordingly, the sovereign has authority, with "the general consent of his Subjects," to establish a "Publick Form of Religion" within the society; to require that it "be professed by all," especially the clergy; and to

See id. ch. IV, § IX, at 67-69.

Id. at 67 .

124 Samuel Pufendorf, Of the Nature and Qualification of Religion in Reference to CIVIL SOCIETY (Simone Zurbuchen ed., Jodocus Crull trans. 1698, Liberty Fund 2002), https://oll.libertyfund.org/titles/pufendorf-of-the-nature-and-qualification-of-religion-in-reference-tocivil-society [https://perma.cc/ALF3-K58Q] [hereinafter PUFENDORF, RELIGION].

${ }_{125}$ See Simone Zurbuchen, Introduction to id., at xi.

${ }_{126}$ Pufendorf, RELIGION, supra note $124, \S \S 1-3$, at 12-15.

$127 \quad I d . \$ 5$, at 17 .

${ }^{128} \quad$ See id. $\$ 7$, at 20 .

129. Id. $\$ 49$, at $104,106$. 
command that its "Doctrine be Taught both in publick and private." ${ }^{130}$ When doctrinal disputes arise, the sovereign may convene synods to resolve them. ${ }^{131}$ Individuals who insist on teaching "erroneous Doctrines" may be "silenced" or-if all else fails-"banished." ${ }^{132}$ The sovereign also has authority to ensure that the church has adequate revenues, to erect and maintain church buildings and schools, and to play a limited role in the selection of ministers. ${ }^{133}$

This account of Pufendorf's views raises a puzzle. How is it possible to reconcile his position that religious liberty is an inalienable aspect of natural liberty, and that civil government is established for the sake of security rather than religion, with his approval of the establishment of a public religion and his view that the government is not necessarily bound to grant toleration to religious dissenters? The answer appears to lie at least partly in his views on natural and revealed religion and on the role of religion in society. In contrast to Locke, Pufendorf seems to hold that natural religion has no effect whatever in promoting the salvation of souls, which can come about only in the ways offered by divine revelation. ${ }^{134}$ From the standpoint of natural law, the function of natural religion-and religion in general-is to provide the "Bond" or "Cement" of human society, by giving individuals the strongest possible incentive to obey the laws and refrain from harming one another. ${ }^{135}$ In a society whose members are Christians, the only religion that is capable of holding the society together is Christianity. ${ }^{136}$ Thus, in such a society, the government should promote not only the principles of natural religion but also Christian beliefs and worship, by establishing them as the public religion of the commonwealth. ${ }^{137}$ That does not mean that the government is justified in imposing a religion on individuals by force, for that would conflict with their

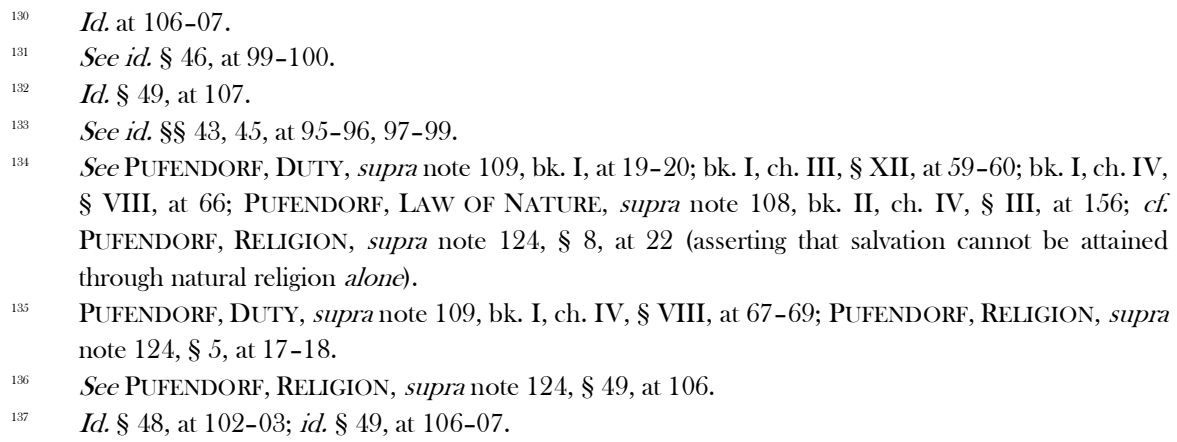


innate freedom as well as with the very nature of religion, which can be apprehended only by reason and faith. ${ }^{138}$ Within limits, it may be appropriate to tolerate those who differ from the public religion, especially when they are willing to live quietly and peaceably in the society. ${ }^{139}$ But when religious dissent threatens to undermine social peace and order, the government has the authority to suppress it or, as a last resort, to expel the dissenters. ${ }^{140}$

In this way, Pufendorf seeks to reconcile the competing values of individual liberty and social order in the area of religion. He does this by recognizing a limited right to religious freedom while at the same time defending the traditional institution of an established church, now reconceived as an institution that promotes social order as much as one that advances true religion and the salvation of souls. The tensions and contradictions that exist within this view are obvious, for although Pufendorf insists that civil government is not formed for the sake of religion, the powers that he grants the government in this area may result in far-reaching limits on religious liberty. In this respect, his position stands in striking contrast to that of Locke, who takes the idea of a natural and inalienable right to religious liberty to its logical conclusion by holding that the state has no power whatever in the religious sphere. ${ }^{141}$

See id. $\$ 1-3$, at 12-15.

See id. $\$ \$ 49-50$, at 105-08.

See supra text accompanying note 132 .

" See supra text accompanying notes 90-93. In their own treatises on the law of nature and nations, Burlamaqui and Vattel follow Pufendorf in recognizing substantial authority in the sovereign over religious teaching and worship, while at the same time affirming that subjects have an inviolable natural right to liberty of conscience. See Jean-Jacques Burlamaqui, The Principles of Natural and POLITIC LaW vol. 2, pt. III, chs. II-III, at 404-15; pt. IV, ch. II, \$\$ XXXII-XXXVI, at 460-62; ch. VIII, § XVI, at 515 (Petter Korkman ed., Thomas Nugent trans., Liberty Fund 2006) (2d ed. 1763), https://oll.libertyfund.org/titles/burlamaqui-the-principles-of-natural-and-politic-law [https://perma.cc/G6HQ-Z3B5]; EMER DE VATTEL, THE LAW OF NATIONS bk. I, ch. XI, § 114, at 147-49, id. ch. XII, $\$ \$ 125-57$, at 155-85 (Béla Kapossy \& Richard Whatmore eds., Liberty Fund 2008) (1797), https://oll.libertyfund.org/titles/vattel-the-law-of-nations-lf-ed [https://perma.cc/4T6BN6G9]. By contrast, in his notes on Pufendorf, the great commentator Jean Barbeyrac endorses Locke's views on religious toleration and the separation of church and state. See PuFENdorf, LAw OF NATURE, supra note 108, bk. VII, ch. IV, § XI, n.2, at 665-66 (Barbeyrac's note). The concept of natural religion also was an important one for all these authors. See, e.g., BURLAMAQUI, vol. 1, pt. II, ch. IV, §§ VII-VIII, at 148-50; VATTEL, The LAW OF NATIONS, bk. I, ch. XII, § 127, at 157-58; Jean Barbeyrac, An Historical and Critical Account of the Science of Morality, in PUfeNdORF, LAW OF NATURE, supra note 108, § I, at 1-3; § VI, at 14-16; § 32, at 86-88. 
We can therefore view Locke and Pufendorf as representing two competing models of religious liberty and its relationship to the state. Both thinkers begin with the notion that human beings are rational creatures who are inherently free to use their minds to pursue the truth about God. For Locke, this religious liberty amounts to an inviolable natural right and the state has no authority with regard to religion. By contrast, Pufendorf holds that the state may limit this liberty for the sake of social order, which he believes is best ensured through the traditional means of an established religion. The history of religious freedom in the eighteenth century involves an ongoing conflict between these two models. We now turn to some of the ways this debate played out within the English legal tradition.

\section{B. English Law and the Toleration Act of 1689}

For founding-era Americans, one of the most authoritative articulations of natural law could be found in Sir William Blackstone's Commentaries on the Laws of England. ${ }^{142}$ In this work, Blackstone not only presents a comprehensive account of English law, but also seeks to rationalize and defend that law by showing that it is consonant with the law of nature. ${ }^{143}$ Following the tradition that we are exploring, Blackstone explains that, as rational creatures endowed with free will, human beings are necessarily subject to the rules of justice that God has established for their conduct-rules that are founded in "the nature of things," that are discoverable by reason, and that are intended to direct people toward their own "real happiness." ${ }^{\text {14 }}$ In addition to duties toward God, including worship and obedience, these rules prescribe the duties that one owes to oneself and one's neighbor. ${ }^{145}$ Taken as a whole, these duties make up "what we call ethics, or natural law," or "natural religion." ${ }^{146}$

142 William Blackstone, Commentaries on the Laws of England (Wilfrid Prest gen. ed., Oxford Univ. Press 2016) (1765-69) [hereinafter Blackstone, Commentaries].

143 See, e.g., 1 BlaCKSTONE, COMMENTARIES, supra note 142, introduction $\$ 1$, at 32-36 (arguing that English law reflects the fundamental laws of nature). All page references herein are to the first edition of the Commentaries.

14 Id. $\$ 2$, at 39-41.

${ }_{14}$ IId at $39,45,54$.

It. Id at 41,55 . 
This account of natural law provides the foundation not only for "natural duties" but also for "natural rights." ${ }^{17}$ Those rights consist of personal security, personal liberty, and private property. ${ }^{18}$ After canvassing the ways that they are recognized and protected by English law, Blackstone boasts that (as Montesquieu put it) England "is the only nation in the world, where political or civil liberty is the direct end of its constitution."

Yet in many ways Blackstone struggles to reconcile the principles of liberty with the needs of social order and the content of English law. Nowhere is this clearer than in his discussion of the criminal law regarding "Offences Against God and Religion." ${ }^{150}$ Blackstone voices the liberal sentiment that all religious persecution is "highly unjustifiable upon every principle of natural reason, civil liberty, or sound religion." ${ }^{\text {sil }}$ But he cautions that this position should not be taken "into such extremes, as may endanger the national church," for "there is always a difference to be made between toleration and establishment." ${ }^{\text {"152 }}$ "[T]he preservation of christianity, as a national religion" is essential not only because of "its own intrinsic truth," but also because of its importance to "the civil state." ${ }^{\text {"153 }}$ For example, all confidence in oaths and other forms of veracity would be undermined if people did not believe in "a future state of rewards and punishments"-a belief that is "clearly revealed" and "forcibly inculcated" by the teachings of Christ. ${ }^{154}$ The government therefore is justified in punishing "all affronts to christianity" or to the established church. ${ }^{1.55}$ Although in the past some measures were excessively harsh, "[e]very thing is now as it should be." ${ }^{157}$ In particular, Blackstone defends the existing laws against apostasy, heresy, blasphemy, and reviling the worship or liturgy of the Church

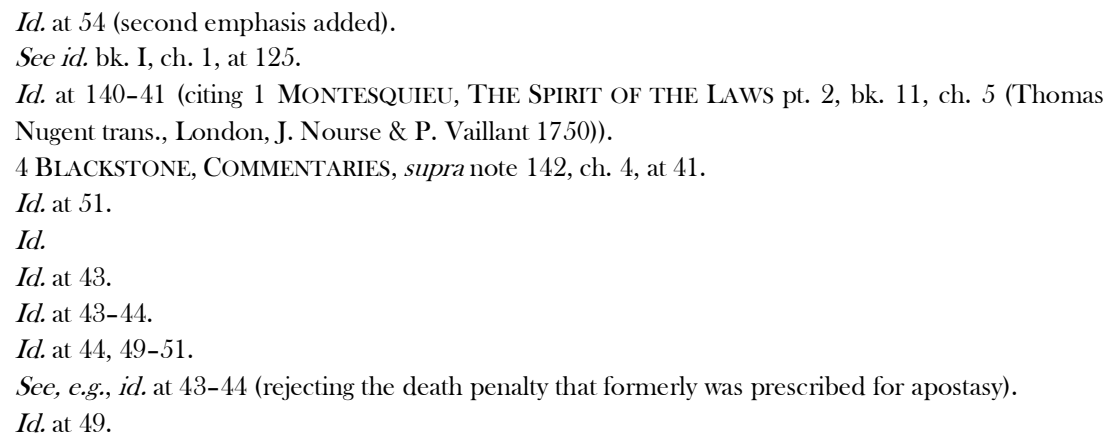


of England. ${ }^{1.58}$ He also denounces "the protestant dissenters" whose "spirit" and "doctrines" had led them to overthrow the church and the monarchy during the Civil War. ${ }^{159}$ Concededly, the Restoration Parliament went too far when it criminalized mere nonconformity to, or separation from, the established church, however much such conduct might proceed from "perverseness," "weakness of intellect," or "misguided piety." ${ }^{60}$ But the legislature acted with "a spirit of true magnanimity" when it enacted the Toleration Act of 1689, which suspended the penal laws with regard to many Protestant dissenters, thereby leaving them "at full liberty to act as their conscience shall direct them, in the matter of religious worship." ${ }^{161}$ At the same time, Blackstone praises the Corporation and Test Acts, which reserved all civil offices to members of the national $\operatorname{church}^{162}-\mathrm{a}$ policy that he insists is inherent in the very "idea of a national establishment."

Shortly after its appearance in 1769, Blackstone's discussion drew a sharp rebuke from a leading English nonconformist, Joseph Priestley, who objected not only to his narrow view of religious liberty but also to the harsh language he directed against Protestant dissenters. ${ }^{16 t}$ In response, Blackstone explained that he had intended that language to refer not to contemporary dissenters but to their ancestors, the Puritans who had overthrown the monarchy in the $1640 \mathrm{~s}{ }^{165}$ Conceding that his language was ambiguous, he promised to revise it

58 $\quad$ See id. at 43-51, 59 .

$159 \quad I d$ at 52.

${ }_{100} \quad$ See id. at $52-53$.

${ }^{161} \quad I d$ at 53 . By contrast, Blackstone argues that Parliament historically was justified in enacting severe penal laws against Catholics because of the threat they posed to the state. See id. at 54-57. But he expresses hope that as this threat diminishes, the laws against Catholics also will be eased. See id. at 57.

162 Corporation Act, 13 Car. II Stat. 2 c. 1 (1661); Test Act, 25 Car. II c. 2 (1672).

${ }_{163} 4$ Blackstone, COMMENTARIES, supra note 142 , ch. 4, at 52-53, 57-58.

164 Joseph Priestley, Remarks on Some Paragraphs in the fourth Volume of Dr. Blackstone's COMmentaries on the Laws of England Relating to the Dissenters (1769), reprinted in AN INTERESTING APPENDIX TO SiR William Blackstone's COMMENTARIES ON THE LAWS OF ENGLAND 5 (1773), https://ia600207.us.archive.org/31/items/i nterestingappen05john/interestingappen05john_bw.pdf [https://perma.cc/99K5-UFL2] [hereinafter INTERESTING APPENDIX].

165 William Blackstone, A Reply to Dr. Priestley's Remarks on the Fourth Volume of THE COMMENTARIES ON THE LAWS OF ENGLAND (1769), reprinted in INTERESTING APPENDIX, supra note 164 , at 35,39 . 
in the next edition. ${ }^{166} \mathrm{He}$ also stressed his commitment to religious liberty. ${ }^{167}$ At the same time, he insisted that nonconformity was still a crime under English law and that this crime was only partly done away with by the Toleration Act. ${ }^{168}$

The controversy continued the following year with the publication of a work called Letters to the Honourable Mr. Justice Blackstone by the English dissenting minister Philip Furneaux. ${ }^{169}$ As Furneaux read the Commentaries and the reply to Priestley, Blackstone maintained that the Toleration Act did not abolish the crime of nonconformity even with respect to Protestant dissenters, but merely suspended the penalties that the law would have imposed on them. ${ }^{170}$ In response, Furneaux contended that religious liberty was among the most sacred and valuable "rights to which men are entitled by nature," and that the nation had recognized this when it adopted the Toleration Act. ${ }^{171}$ On this view, the Act should be interpreted not merely to suspend the penalties for nonconformity but to completely relieve that conduct of its criminality. ${ }^{172}$

As support for this position, Furneaux pointed to a recent judicial decision known as the Sheriff's Case. ${ }^{173}$ For some years, electors in London had carried on a scheme to raise money for a new city hall. They would elect to office a




person who was known to be a Protestant dissenter, and who therefore was barred from holding municipal office by the Corporation Act. ${ }^{174}$ Under the terms of a London by-law, the person was then subjected to a heavy fine for refusing to undertake the office to which he had been elected. ${ }^{175}$ The dissenters eventually mounted a legal challenge to this practice. ${ }^{176}$ In 1767 , they prevailed when the House of Lords ruled in favor of a nonconformist named Alan Evans who had been elected sheriff. ${ }^{177}$ In an eloquent opinion, William Murray, Baron Mansfield, who was Lord Chief Justice of the Court of King's Bench, declared that nothing is "certainly more unreasonable, more inconsistent with the rights of human nature, more contrary to the spirit and precepts of the Christian Religion, more iniquitous and unjust, more impolitic, than Persecution. It is against Natural Religion, Revealed Religion, and sound Policy." under which "the Dissenters way of worship ... is not only exempted from punishment, but rendered innocent and lawful; it is established: it is put under the protection ... of the law." ${ }^{\text {"179 }}$ For these and other reasons, the city's scheme was unlawful. ${ }^{180}$

Furneaux's critique of Blackstone also relied on another leading decision called Omichund v. Barker. ${ }^{181}$ In that case an Indian merchant from Calcutta sued an English official for financial fraud. ${ }^{182}$ The defendant responded that because the plaintiff was Hindu, his testimony was inadmissible because he was "incapable of swearing upon the Gospels." "183 The judges rejected this contention. Invoking Pufendorf and almost "[a]ll other Writers in Divinity, Morality, the Law of Nature or Nations, or any other Science relative to this Subject," Lord Chancellor Hardwicke explained that the practice of taking

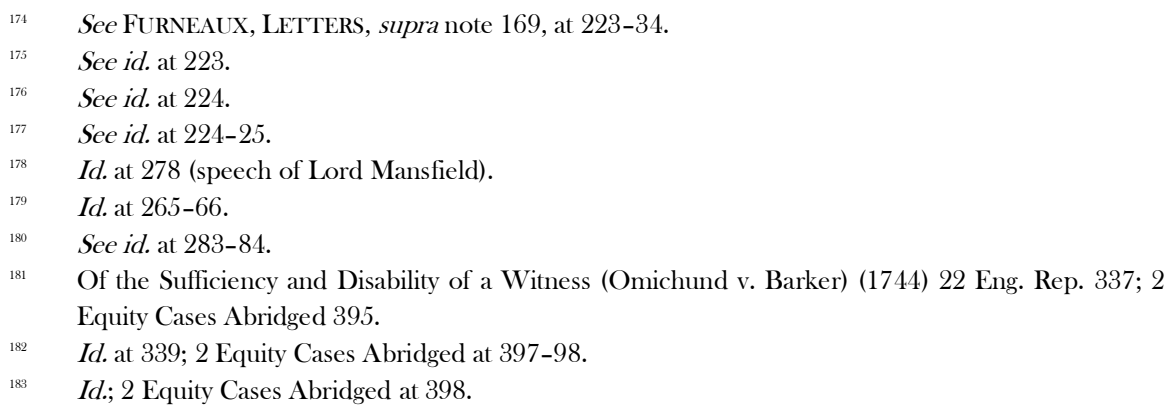


oaths was not peculiar to Christianity but "follows from the Principles of Natural Religion." ${ }^{\text {"st }}$ All that was required was that the oath taker believe in "a God, and that he will reward and punish Men for their Actions" if they swear falsely. ${ }^{185}$ The judges concluded that individuals were entitled to give evidence by swearing in the manner prescribed by their own religions. ${ }^{186}$ In his Letters, Furneaux cites Omichund to support his argument that natural religion and not revelation is the foundation of judicial oaths, and so there is no justification for punishing individuals merely because their regard for oaths is based on considerations other than Christian doctrine. ${ }^{187}$

In response to objections from writers like Priestley and Furneaux, Blackstone made certain changes to the Commentaries. ${ }^{188}$ But while those changes softened the tone of his discussion, they were unable to resolve the deep contradictions that lay at the heart of his effort to reconcile principles of religious liberty with the establishment of religion, at least as the latter was embodied in the English law of his day.

In addition to criticizing Blackstone's position, Priestley and Furneaux published affirmative arguments for religious liberty. In An Essay on the First Principles of Government, Priestley argued that "the best interests of mankind" would be promoted by "unbounded liberty, in matters of religion." ${ }^{189}$ Furneaux's Essay on Toleration made a Lockean case for religious freedom based on "the nature of religion" as well as "the origin, and the ends, of civil government." ${ }^{900}$ As we shall see, Furneaux's writings made a strong

184 Id. at 347; 2 Equity Cases Abridged at 408 (opinion of Hardwicke, C.).

185 Id. at 344; 2 Equity Cases Abridged at 404 (opinion of Willes, C.J.); see also id. at 345; 2 Equity Cases Abridged at 405-06 (opinion of Lee, C.J.).

${ }^{186}$ See id. at 350; 2 Equity Cases Abridged at 412 (opinion of Hardwicke, C.).

${ }_{187}$ FurNEAUX, LETTERS, supra note 169, Letter III, at 67-69 \& 69 n. *

188 For a comprehensive account of these changes, see 4 BLACKSTONE, COMMENTARIES, supra note 142, at 294-300 (Varia to Chapter 4).

189 Joseph Priestley, an Essay on the First Principles of Government, and on the Nature of Political, Civil, ANd Religious Liberty 115 (London, J. Johnson, 2d ed. 1771) https://oll.libertyfund.org/titles/priestley-an-essay-on-the-first-principles-of-government [https://perma.cc/X8L5-VB74].

190 Philip Furneaux, An Essay on Toleration \$\$ I-II, at 8-25 (photo. reprt. n.d.) (London: T. Cadell, 1773) [hereinafter FurNeAuX, TOLERATION]. 
impression on Jefferson and Madison and contributed in important ways to their views on religious liberty. ${ }^{191}$

\section{Moral Philosophy}

During the eighteenth century, one strand of British philosophy emphasized the role of reason in morality while another stressed the importance of emotion. The concepts of natural law and natural religion held an important place in both views.

\section{Sentimentalism and the Scottish Enlightenment}

As many scholars have shown, founding-era Americans were substantially influenced by the thinkers of the Scottish Enlightenment. ${ }^{192}$ That is especially true of Francis Hutcheson, a Presbyterian minister who held the chair of moral philosophy at the University of Glasgow from 1729 to $1746 .{ }^{193}$ Hutcheson's views were developed in a series of works that culminated in A System of Moral Philosophy. ${ }^{194}$

Hutcheson holds that the purpose of moral philosophy is to direct human beings to the course of action that will "promote their greatest happiness and perfection," insofar as this can be discerned through observations "from the constitution of nature" without the assistance of "supernatural revelation." The resulting rules of conduct are "called the LAW OF NATURE." "196

In contrast to theorists like Locke and Pufendorf, however, Hutcheson rejects the notion that morality is primarily based on reason. ${ }^{197}$ Instead, he contends that just as human beings have an aesthetic sense that enables them

${ }_{191}$ See infra notes 445, 471, 473 and accompanying text.

192 See, e.g., GARRY Wills, INVENTING AMERICA (1978). For an overview of this school of thought, see Knud Haakonssen, Natural Law and Moral Philosophy (1996).

193 See 28 Dictionary of National Biography 333 (Sidney Lee ed., London, MacMillan \& Co. 1891), https://archive.org/details/dictionaryofnati28stepuoft.

194 Francis Hutcheson, A System of Moral Philosophy (photo. reprt.) (Glasgow, R. \& A. Foulis 1755), https://archive.org/details/systemmoralphilo01hutc/page/n6 [https://perma.cc/XR5L9AVE] [hereinafter HuTCHESON, SYSTEM].

$195 \quad 1$ id. bk. I, ch. I, $\$$ I, at 1.

$196 \quad I d$.

${ }_{197}$ See id. bk. I, ch. 4, § III, at 56-57. 
to perceive the beauty of objects, they have a moral sense that enables them to perceive the goodness of intentions and of the actions that follow from them. ${ }^{198}$ This goodness consists in benevolence or the desire to promote "the happiness of others." ${ }^{199}$

On this view, morality is ultimately a matter of the heart rather than the head. ${ }^{200}$ Yet reason does hold an important place in Hutcheson's scheme. Although the moral sense can recognize that goodness consists in universal benevolence, reason is needed not only to "corroborate" our moral sense but also to determine what actions will in fact promote the good. ${ }^{201}$ The conclusions that reason reaches on this subject constitute the laws of nature. ${ }^{202}$

Following the Christian tradition, Hutcheson maintains that the essence of those laws consists in love toward God and neighbor. ${ }^{203}$ Two chapters of the System are devoted to duties toward God. ${ }^{204}$ After reciting the traditional arguments for his existence, Hutcheson focuses on what reason can ascertain about his moral character. ${ }^{205}$ By reflecting upon the order and harmony of the visible world as well as upon their own nature and moral sentiments, human beings can recognize that God is benevolent, that he created "rational creatures" from "a desire to communicate [his own] perfection and happiness" to them, that he "exercises an universal providence" over the world, and that his laws are "good and just, adapted to the interest and perfection of the whole.” 206 Indeed, Hutcheson goes so far as to contend that God's benevolence provides good reason to hope in eternal life, a future state in which virtuous conduct will be rewarded..$^{207}$ "Th[is] opinion," he asserts, "is natural to mankind, and what [God] designed they should entertain."

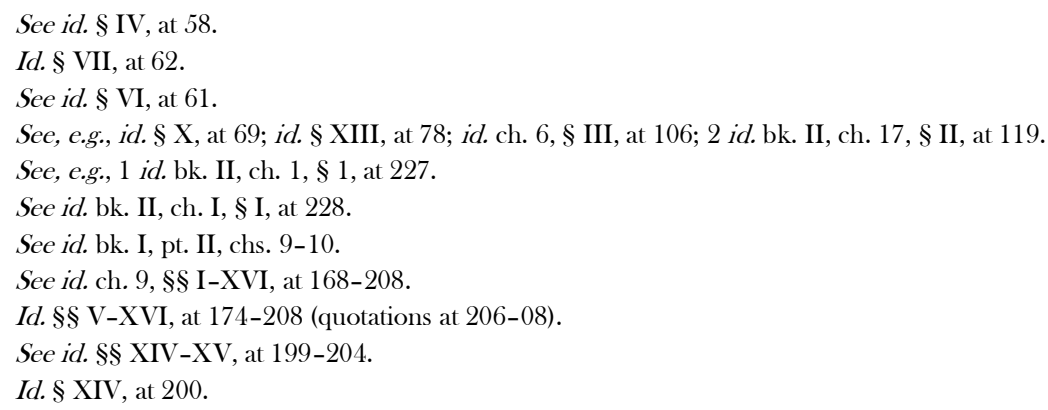


On this view, God himself is "the source of the highest happiness to [rational creatures], the noblest object of their contemplation and veneration, of their love, esteem, hope, and secure confidence, and the best pattern for their imitation." ${ }^{209}$ This is "the foundation of all piety, and all joy in religion." Hutcheson then elaborates upon the natural duty to worship God both internally-"in the sentiments and affections of the soul"-and externally_-in the natural expression of these ... sentiments and affections" though instruction, praise, prayer, repentance, and so on. ${ }^{211}$

In these ways, reason confirms what Hutcheson regards as the natural human disposition toward piety and devotion. ${ }^{212}$ "Notions of Deity and some sort of worship have in fact as universally obtained among men, as living in society, the use of speech, or even propagating their kind; and thus may be counted as natural." ${ }^{213}$

According to Hutcheson, natural religion is also more fundamental than revealed religion. The "primary way by which God discovers his will concerning our conduct" is not by Scripture but by "the constitution of nature, and the powers of reason, and moral perception, which he has given to mankind.” ${ }^{214}$ Revelation supplements reason, but God does not mean to treat human beings as "children" by relieving them of the responsibility to discover for themselves how they ought to live..$^{215}$

Hutcheson's account of natural religion provides the foundation not only for a moral duty of religious worship but also for a right to religious freedom. As he explains, it "must always be unjust" to compel people to profess religious opinions or to perform religious actions contrary to their beliefs, "as no interest of society can require it, and such profession and action must be sinful to those who believe it to be so." ${ }^{216}$ Nor is this "right of private judgment"

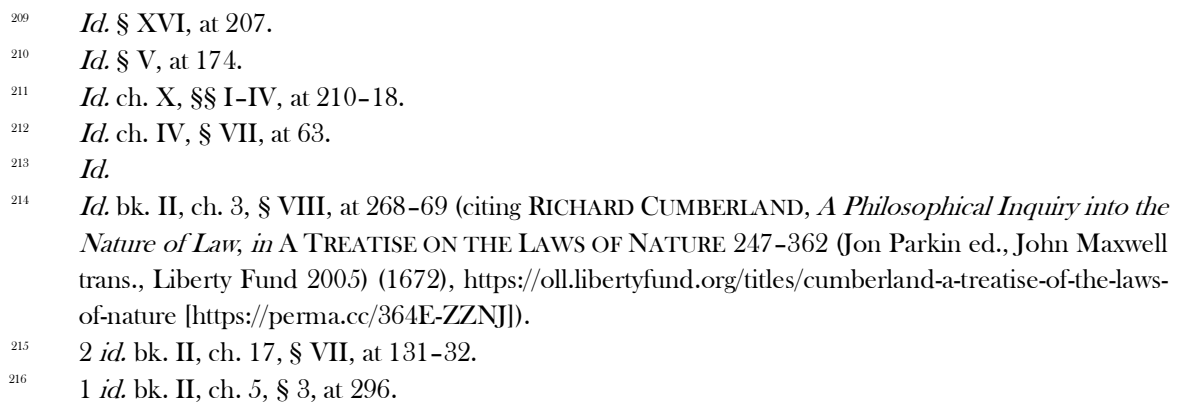


confined to the religious sphere. ${ }^{217}$ Instead, Hutcheson holds that "every intelligent being" has a right to form "his own opinions" on all subjects. ${ }^{218}$ This right is an "unalienable" one which "cannot be subjected to the will of another." ${ }^{219}$

At the same time, Hutcheson observes that few people have both the time and the inclination to "exercise this right of private judgment vigorously.",220 Thus, to promote the good of society and to "prevent the influence of dangerous enthusiasts or rogues," it is both the interest and the duty of the magistrate to appoint persons to provide moral and religious instruction to the people. ${ }^{221}$ But while the government does have a limited role in promoting religion, it must do so in a way that does not compel individuals to worship in a particular manner and does not impose punishment for religious sentiments, so long as "they are not hurtful to society" or used as a pretense for "invading the rights or properties of others." ${ }^{222}$

Hutcheson's general approach to morality also can be found in later Scottish philosophers such as Adam Smith, ${ }^{223}$ Thomas Reid, ${ }^{224}$ and Henry Home, Lord Kames. ${ }^{225}$ Although they differed with one another in important respects, they all maintained that morality was rooted in the senses or feelings, and the idea of natural religion held an important place in their thought. Smith's views are particularly interesting. In The Theory of Moral Sentiments, he argues that religion is natural to human beings, and he connects it with their

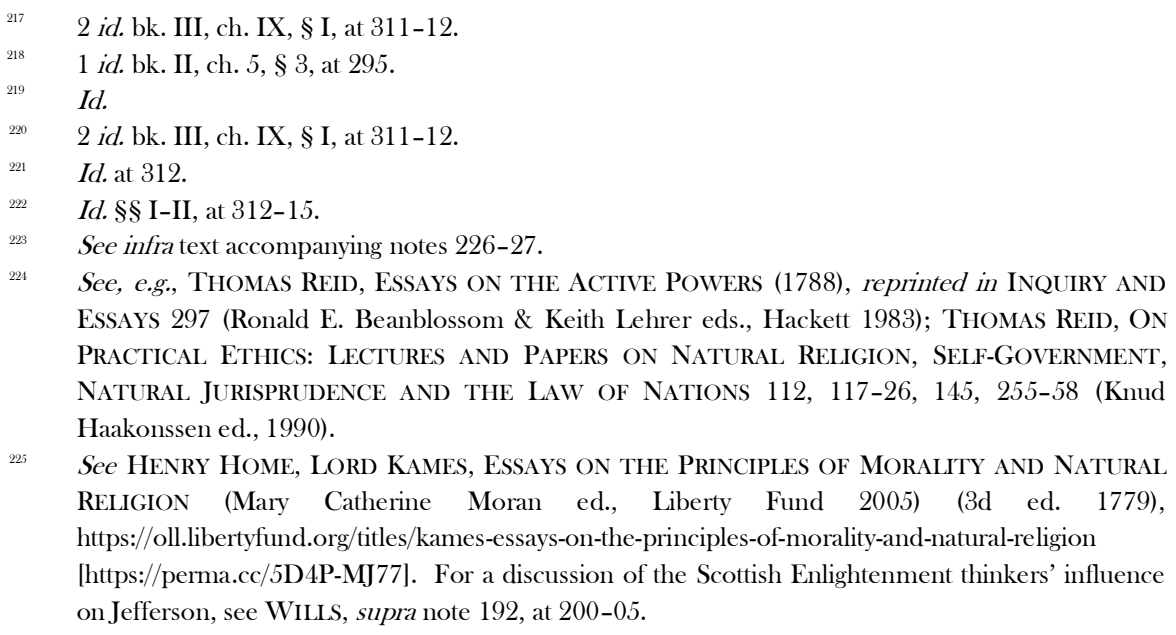


sense of justice and with belief in an afterlife. ${ }^{226}$ And in The Wealth of Nations, he argues that the interests of individual liberty, social peace, and rational religion all would be promoted by doing away with establishments that grant monopolies to particular sects and by instead allowing many small sects to compete with one another for adherents. ${ }^{227}$

\section{Rationalism}

Other British philosophers based morality on reason rather than sensation. A good example is Richard Price, a liberal clergyman who was wellknown to Americans as a strong supporter of their Revolution. ${ }^{228}$

In A Review of the Principal Questions in Morals, Price maintains that theorists like Hutcheson undermine the objectivity of morality when they base it on the sensations that individuals experience when they perceive actions. ${ }^{229}$ Instead, Price holds that morality is founded on "self-evident principles" that can be discerned through reason and intuition, such as the precepts that it is right for intelligent beings to pursue happiness and wrong for them to violate the rights of others or to inflict misery on innocent persons. ${ }^{230}$ "Reason is ... the natural and authoritative guide of a rational being," and the morality that it

${ }^{226}$ See AdAM SMith, The TheORY OF MORAL SENTIMENTS pt. II, sec. ii, ch. 3, \$§ 11-12, at 91; id. pt. III, ch. 2, \$§ 3-13, at 163-70 (D.D. Raphael \& A.L. Macfie eds., Oxford Univ. Press 1976) (6th ed. 1790).

227 See 2 AdAM SMith, AN INQUiRY INTO THE NATURE AND CAUSES OF THE WEALTH OF NATIONS bk. V, ch. I, pt. III, art. III, at 273-79 (Edwin Cannan ed., London, Methuen 1904), https://oll.libertyfund.org/titles/smith-an-inquiry-into-the-nature-and-causes-of-the-wealth-of-nationscannan-ed-vol-2 [https://perma.cc/9JUR-7BXD].

228 See Richard Price, Two Tracts on Civil Liberty, the War with America, and the Debts and Finances of the Kingdom (1778), in Political Writings 14-19 (D.O. Thomas ed., Cambridge Univ. Press 1991) [hereinafter Price, Two TraCts]; MAY, supra note 15, at 171. For an exploration of Price's moral philosophy, see J.B. SCHNEEwind, The Invention of Autonomy: A History of Modern Moral Philosophy 380-88 (1998). Some other leading treatments of morality and natural religion from a rationalist perspective include those of Samuel Clarke, see infra text accompanying notes 280-85, and William Wollaston, see William Wollaston, The Religion of Nature Delineated (London, S. Palmer 1725), https://play.google.com/store/books/details?id=H68WAAAAQAAJ\&rdid=bookH68WAAAAQAAJ\&rdot=1 [https://perma.cc/3NT2-E5PR].

229 Richard Price, A Review of the Principal Questions in MORAls ch. I, § 1, at 13-17 (D.D. Raphael ed., London, Clarendon Press 1974) (3d ed. 1787).

25ee id. $\$ 3$, at 45,53 ; ch. VII, at 157-64, 168 . 
dictates is a "universal LAW" that governs not only humans but "[t]he whole creation." "It "It is the source and guide of all the actions of the Deity himself, and on it his throne and government are founded." ${ }^{232}$

As this discussion indicates, Price's account of reason and morality is closely connected to the idea of natural religion. God is the creator of the world, the embodiment of moral perfection, and "the fountain of reason and wisdom.” ${ }^{233}$ Human beings depend on him for their existence and wellbeing. ${ }^{234}$ For these reasons, it is inherently proper for them to love, honor, and worship him as well as to trust in "his all-directing providence." ${ }^{235}$

In the book's final chapter, Price returns to these themes and contends that his account of morality can help to explain and prove "some of the principal Doctrines of Natural Religion." ${ }^{236}$ From the ideas that morality and the divine will are founded on reason, one can infer that the Deity is benevolent, that he created the world to promote the happiness of his creatures, and that he governs it in accord with justice. ${ }^{237}$ Because justice does not always prevail in this world, it is reasonable to believe that there is a future state in which individuals will be rewarded or punished for their conduct in this life. ${ }^{238}$ Yet there are limits to what reason can tell us about an afterlife. ${ }^{239}$ It is here that "the Christian revelation" is particularly valuable, for in addition to "confirm[ing] to us whatever we can gather from reason on these subjects," it promises that the virtuous will enjoy a never-ending life of "complete happiness. ${ }^{240}$

Price's account of natural religion and morality also provides a justification for liberty of conscience. After doing our best to determine whether a course of conduct is right or wrong, we have a duty to act according to "the sincere

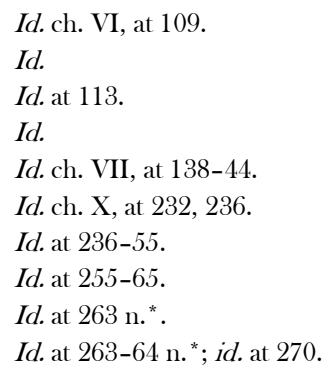


conviction of our minds." ${ }^{241}$ To be sure, society is entitled to act in "necessary self-defense, when the consciences of men lead them to hurt others, to take away their liberty, or to subvert the publick." ${ }^{12}$ In all other cases, however, it is not only impious but

a contradiction to common sense ... for any men to pretend to a power to oblige their fellow men to worship God in any manner different from that which is most agreeable to their consciences; that is, in any way but that in which alone it is acceptable and right in them to do it. ${ }^{223}$

In his writings on the American Revolution, Price expands on this view, describing "religious liberty" as one of "the unalienable rights of human nature" ${ }^{2 n}$ and firmly connecting it with the idea of "a rational and liberal religion. ${ }^{{ }^{25}}$

\section{Uniting Reason and Sentiment}

Although philosophers like Hutcheson and Price differed in their methodology, the substance of their teachings on morality and natural religion had much in common. This is an important theme in the lectures on moral philosophy delivered later in the century by the Rev. John Witherspoon, the president of the College of New Jersey (later Princeton), who was a leader in revolutionary politics and a signer of the Declaration of Independence. ${ }^{26}$ Although he agrees with Hutcheson that moral sense or conscience is an essential "principle of our nature," Witherspoon sees no occasion to reject reason as an equally important principle. ${ }^{217}$ Instead, after reviewing these and other approaches to morality, he concludes that "we ought to take the rule of

24I Id. ch. VIII, at 179.

212 Id.

${ }_{213} \quad$ Id

24 Price, Two Tracts, supra note 228, at 33, 81. Once again, Price insists that this liberty does not entitle one to "encroach on the equal liberty of others," for it would be contradictory to hold "that every one had a right to enjoy what every one had a right to destroy." Id. at 81 .

245 Richard Price, ObSERVATIONS ON THE IMPORTANCE OF THE AMERICAN REVOLUTION (1785), in Political Writings, supra note 228, at 116, 133 [hereinafter Price, ObSERvations].

${ }^{246}$ John Witherspoon, Lectures on MORAl Philosophy (photo reprt., n.d.) (Varnum Lansing Collins ed., Princeton Univ. Press 1912) (1800), https://play.google.com/store/books/details ?id=M2gVAAAAYAAJ\&rdid=book-M2gVAAAAYAAJ\&rdot=1 [https://perma.cc/7 K3P-YM3T]. On Witherspoon, see J. David Hoeveler, Creating the American Mind: Intellect and POlitics in COlOnial COlleges 117-27 (2002); Miller, supra note 10, at 135-41, 149-51.

${ }_{277}$ WitherSPOON, supra note 246, lect. III, at 17. 
duty from conscience enlightened by reason, experience, and every way by which we can be supposed to learn the will of our Maker, and his intention in creating us such as we are." ${ }^{218}$

After reviewing the main proofs for the existence of God, Witherspoon turns to the substance of natural religion. ${ }^{219}$ Our internal duties to God require us to love, venerate, and trust him, while our external duties involve the natural expression of these sentiments through worship and prayer. ${ }^{250}$ Witherspoon maintains that "not only private, but public and social worship is a duty of natural religion." "251 Moreover, he agrees with those who contend that "the magistrate ought to make public provision for the worship of God, in such manner as is agreeable to the great body of society." ${ }^{252}$ At the same time, Witherspoon insists that "all who dissent from [this public worship must be] fully tolerated," for every individual has an "unalienable" "right to judge for himself in all matters of religion," as well as in "matters of opinion" more broadly. ${ }^{253}$ Like all other rights, however, religious liberty must not be exercised in a way that violates the rights of others. ${ }^{254}$ These are the doctrines of natural religion and moral philosophy in which James Madison was instructed when he attended Witherspoon's lectures as a Princeton undergraduate in the early $1770 \mathrm{~s}^{2.55}$

\section{Theology}

Remarkably, the concept of natural religion played an essential role not only in disciplines like natural jurisprudence, moral philosophy, and political theory, which were founded on natural reason, but also in much of the theology of the period.

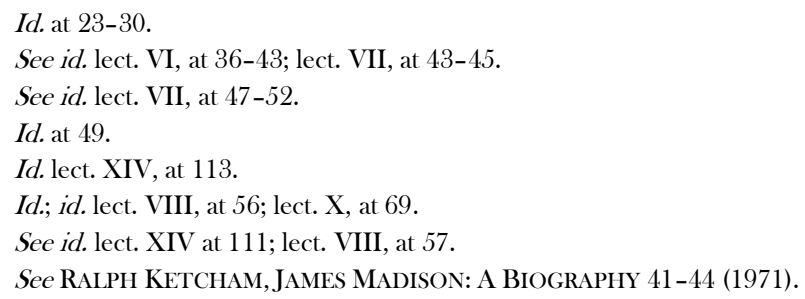




\section{Deism}

Of course, this is true of Deism, which may be defined (in Locke's words) as "pure Natural Religion" or religion based on natural reason. ${ }^{256}$ In De Veritate (1624), a work that is often regarded as the founding text of modern Deism, the English aristocrat Edward, Lord Herbert of Cherbury, maintained that all true religion is founded upon five basic truths that are accessible to everyone through reason. ${ }^{257}$ These truths are that God exists, that he is to be worshipped, that religion should focus on virtue and piety rather than on doctrine or ceremony, that one can atone for misconduct through repentance and amendment of life, and that there is a future state of rewards and punishments. ${ }^{258}$ Herbert did not foreclose the possibility of special revelation from God, but he insisted that individuals must think for themselves and use reason to determine whether something is a revelation or not. ${ }^{259}$

Deism was an increasing topic of discussion in late seventeenth and early eighteenth-century Britain. Some Deists claimed to remain within the Christian tradition in an effort to reform it. ${ }^{260}$ A prominent example was Matthew Tindal, a fellow of All Souls College, Oxford. In Christianity as Old as the Creation, Tindal maintained that the will of God was identical with the "Law of Nature, or Reason;... which is common...to all rational Creatures." "[T] "[Te Design of the Gospel" was not to alter this law but rather to restore it by "free[ing] Men from that Load of Superstition which had been mix'd with it" over the ages. ${ }^{202}$

Tindal's emphasis on reason led him to strongly defend liberty of conscience. Echoing Locke, he wrote that "no Man can any more discern the objects of his own Understanding . . . by the Faculties of another, than he can

LOCKE, REASONABLENESS, supra note 53 , ch. I, at 5 .

${ }^{257}$ Edward, Lord Herbert of Cherbury, De Veritate 5, 292-300 (Meyrick H. Carré trans., J.W. Arrowsmith 1937) (1624). For a valuable discussion of Herbert on which I have relied in this paragraph, see SCHNEEWIND, supra note 228, at 384, 396-99.

258 See SCHNEEWIND, supra note 228, at 396-99.

$259 \quad$ See id. at 401.

2000 See HOLIFIELD, supra note 12, at 160.

${ }^{261}$ Matthew Tindal, Christianity as Old as the Creation 7 (London, 2d ed. 1732), https://archive.org/details/christianityasol00tind/mode/2up [https://perma.cc/M5P5-TTH7].

${ }_{202} \quad I d$. 
see with another Man's Eyes." ${ }^{263}$ It follows that anyone "who demands a Man's Assent to any thing" without conveying reasons adequate to support it "erects a Tyranny over his Understanding., ${ }^{964}$

In this way, Tindal and other "Christian Deists" ${ }^{265}$ sought to reform Christianity by showing that it contained nothing that could not be known through natural reason. ${ }^{266}$ Other Deists took a more critical stance toward Christianity or at least toward the texts on which it claimed to be based. ${ }^{267}$

As E. Brooks Holifield has observed, Deism in eighteenth-century America displayed a similar diversity. ${ }^{268}$ Moderate Deists like Benjamin Franklin and Thomas Jefferson rejected what they regarded as the dogmatism of traditional Christianity and the abuses of clericalism, but supported a form of natural religion and morality which they sometimes associated with Jesus. ${ }^{269}$ By contrast, the end of the eighteenth century saw the rise of more radical thinkers such as Ethan Allen, Thomas Paine, and Elihu Palmer. ${ }^{270}$ This group "was aggressive, populist, polemical, disdainful of a Bible riddled with contradiction and immorality, eager to debunk the gospel stories, and hopeful that a religion of nature would altogether replace an effete Christianity."271

Although Deism attracted considerable attention in late eighteenth-century America, it remained a distinctly minority viewpoint. Yet it was not the only form of religious thought that embraced the concept of natural theology. That concept had a long history in the Christian tradition, ${ }^{272}$ and it took on increasing

2663 Id. at 168 .

264 Id.

265 I Id. at 333.

266 John Toland, another leading Deist, took a similar position when he argued, contrary to Locke, that Scripture cannot teach anything that is above reason, since any such teaching would literally be beyond human comprehension. See John TOland, Christianity NOT Mysterious 6 (London, Samuel Buckley, 2d ed. 1696).

267 See, e.g., HolifieLD, supra note 12, at 160-61 (discussing writings of Deists Anthony Collins and Thomas Woolston examining the religious authority of the Bible).

2068 Id. at $162-70$.

2699 Id. at $162-63$.

270 Id. at 162.

271 Id. Leading works in this vein include ETHAN ALLEN, REASON, THE ONLY ORACLE OF MAN (1784) and Thomas Paine, The age of Reason (1794), reprinted in Thomas Paine: Collected Writings 665 (Eric Foner ed., 1995).

${ }_{272}$ See, e.g., The OXford HandBoOK OF NATURAL Theology chs. 2-5 (Russell Re Manning ed., 2013) [hereinafter OXFORD HANDBOOK] (tracing the concept's use from the Christian Bible through 
importance during the seventeenth and eighteenth centuries. The remainder of this section discusses its role in the Anglicanism which prevailed in the southern states and the Congregationalism which dominated New England.

\section{Anglicanism}

American Anglican thought was rooted in that of the mother country. In the 1640 s, that nation was torn apart by the religious and political struggles that led to the Civil War. After the monarchy was restored in 1660, many Anglican theologians reacted to these bitter conflicts by adopting a more latitudinarian approach which sought to promote religious peace and unity and which contended that the essence of religion lay in morality rather than in ritual or doctrine. ${ }^{273}$

A major figure in this movement was the Rev. John Tillotson, who served as Archbishop of Canterbury from 1691 until his death in 1694. In a sermon entitled "Of the Great Duties of Natural Religion," he asserted that religion is much more concerned with "the real Virtues of a Good Life" than with external devotion. ${ }^{274}$ The moral duties that God requires of human beings are known not solely or even primarily through "External Revelation"; they are also known by "a kind of natural instinct," by "Natural Reason," and by the consensus of mankind. ${ }^{275}$ The duties enjoined by revelation are "the same in

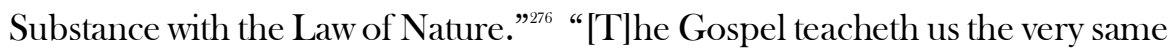
things which Nature dictated to Men before," but it makes those duties more "certain and plain" and offers more powerful motives as well as "a greater Assistance to the performance of [them]. ${ }^{, 27}$

the early modern period). The idea ultimately can be traced back to classical thought. See Stephen R.L. Clark, The Classical Origins of Natural Theology, in id. ch. 1 (describing the notion's development from the pre-Socratics through Plato and Aristotle to Stoicism and Neoplatonism).

${ }^{273}$ See, e.g., Martin I.J. Griffin, JR., Latitudinarianism in the Seventeenth-Century Church of ENGLand (1992).

274 John Tillotson, Of the Great Duties of Natural Religion, with the Ways and Means of Knowing Them, in Several Discourses sermon I, at 8 (Ralph Barker ed., London, Ri. Chiswell 1697), http://name.umdl.umich.edu/A62632.0001.001 [https://perma.cc/5UUN-F2M4].

275 Id. at $16,20-33$.

$276 \quad I d$. at $32-33$

$277 \quad I d$. 
In a companion sermon, Tillotson maintained that "Natural Religion is the Foundation of all Instituted and Revealed Religion," and that "the great Design of the Christian Religion, was to restore and reinforce the practice of the naturalLaw." ${ }^{278}$ Finally, he used this view of the centrality of natural religion to argue that it can never be legitimate to persecute individuals "for not understanding and believing" doctrines that come from revealed religion, for "[n]o Zeal for any positive Institution in Religion, can justifie the Violation of the natural Law," which requires people to treat one another humanely. ${ }^{279}$

The leading Anglican spokesman for rational Christianity during the eighteenth century was the Rev. Samuel Clarke. ${ }^{280}$ In 1704 and 1705, he delivered two sets of lectures in the series that had been endowed by the eminent scientist Robert Boyle to promote natural religion. ${ }^{281}$ In the first set Clarke sought to demonstrate the existence and attributes of God, while in the second he argued for "The Unchangeable Obligations of Natural Religion and the Truth and Certainty of the Christian Revelation." ${ }^{32}$ Natural religion holds "that there is one eternal, infinite, intelligent, all-powerful, and wise being, the creator, preserver, and governor of all things”; that human beings are bound to worship and obey him; that people have a duty to promote the happiness and good of all through a "universal benevolence"; and that they will be subject to "rewards and punishments" in "a future state" for their deeds in this life. ${ }^{283}$

For Clarke, these principles of natural religion and morality can be discerned through reason and should govern every rational being, since they

278 John Tillotson, Instituted Religion Not Intended to Undermine Natural, in Several DISCOURSES, supra note 274, sermon II, at 43, 58, https://quod.lib.umich.edu/e/eebo/A62632.0001 $.001 / 1: 5$ ? rgn=div1;view=fulltext [https://perma.cc/GT5X-YWRL] [hereinafter TILLOTSON, Instituted Religion]. Tindal shows a high regard for Tillotson and quotes him extensively. See, e.g., TINDAL, supra note 261, at 197.

279 Tillotson, Instituted Religion, supra note 278, at 79-80.

${ }^{280}$ For a valuable discussion of Clarke's philosophy and theology, see Timothy Yenter \& Ezio Vailati, Samuel Clarke, The Stanford Encyclopedia of Philosophy (Edward N. Zalta ed., Fall 2018 Edition), https://plato.stanford.edu/archives/fall2018/entries/clarke/ [https://perma.cc/VJ2 S-8JW4].

${ }^{281}$ Samuel Clarke, A Discourse Concerning the Being and Attributes of God, the Obligations of Natural Religion, and the Truth and Certainty of the Christian REVELATION 117 (Edinburgh, A. Allardice 1823) (1711), http://name.umdl.umich.edu/ClarkDisco [https://perma.cc/8S3P-GCMY].

${ }_{282} \quad$ Id. at 117.

${ }_{283} \quad I d$ at $150-52$. 
reflect the inherent and "eternal ... relations that different things bear one to another," such as the relationship that human beings have to God and each other. ${ }^{284}$ But because people are often blinded by carelessness, prejudice, false ideas, bad customs, and unruly desires, God has undertaken to confirm and supplement these principles of natural religion through the Christian revelation. ${ }^{225}$

The rationalism represented by Clarke and Tillotson was one of two major strands of Anglican thought in eighteenth-century America. ${ }^{286}$ It was promoted by such figures as the Rev. William Smith, provost of the College of Philadelphia (which later became the University of Pennsylvania); the Rev. William White, first Episcopal Bishop of Pennsylvania and first Presiding Bishop of the Protestant Episcopal Church in the United States; the Rev. Samuel Provoost, first Episcopal Bishop of New York; and the Rev. James Madison, who was cousin to the statesman, president of the (Anglican) College of William and Mary, and first Episcopal Bishop of Virginia. ${ }^{287}$

A good statement of this rationalist position may be found in a pamphlet published by the Rev. James Maury, a clergyman and professor at William and Mary who "was the first real teacher" of the Rev. James Madison and Thomas Jefferson. ${ }^{288}$ According to Maury, God addresses humans as "creatures endowed with reason" who are capable of distinguishing "between good and evil, right and wrong, truth and falsehood." "Reason and revelation are alike the gifts of GOD," and while unassisted reason "could never have formed that perfect ... rule of religious faith and practice, we are now happily

284 Id. at 156.

285 $\quad$ See id. at 248-49, 278, 293, 306, 336-37.

266 See MARK A. NOLL, AMERICA'S GOD 121 (2002); see also MAY, supra note 15, at 11-12, 17, 2021, 38, 350 (discussing the influence of Tillotson and Clarke in colonial America).

${ }^{287} \quad$ See NOLL, supra note 286, at 120-21; Charles Crowe, Bishop James Madison and the Republic of Virtue, 30 J.S. HisT. 58 (1964). The other main school of American Anglicanism during this period was the High Church theology associated with the Rev. Samuel Johnson, the first president of King's College (later Columbia University), and Samuel Seabury, the first Episcopal Bishop of Connecticut. See NOLL, supra note 286, at 120-21.

288 Thomas E. Buckiey, Establishing Religious Freedom 43 (2013) [hereinafter Buckiey, Establishing]; James Maury, To Christians of Every Denomination among Us, Especially Those of the Established Church, An Address 3 (Annapolis, Anne Catharine Green 1771).

$289 \quad$ MAURY, supra note 288 , at 8. 
blessed with; yet we contend the God of nature never designed revelation entirely to supersede the use of, but only to be, as it were, supplemental to our natural reason." ${ }^{920}$ In line with these views, Maury condemned "that narrow and uncharitable, that merciless and antichristian spirit, which presumes to limit the divine favour only to some few," and which would consign "all the rest of mankind" to fiery persecution in this world and "eternal damnation" in the next. ${ }^{291}$

\section{New England Congregationalism}

The Puritans who settled New England brought with them a strong form of Calvinist theology. The most authoritative statement of their views appears in the Westminster Confession of Faith, ${ }^{202}$ which was adopted by an assembly of divines in England in 1646 and endorsed two years later by a convention of clergy in Massachusetts Bay. ${ }^{293}$ In line with natural religion, the confession opens by affirming that "the Light of Nature, and the works of Creation and Providence ... manifest the Goodness, Wisdom, and Power of God." ${ }^{294}$ After the Fall of Adam, however, human nature is so deeply "corrupted" that people are imbued with original sin, naturally inclined to evil, and subject to "the wrath of God." ${ }^{295}$ Thus, mere natural religion is utterly incapable of bringing about salvation, which can only come through grace and faith in Christ. ${ }^{296}$ Likewise,

\footnotetext{
$290 \quad I d$. at 9 .

${ }_{291} \quad I d$. at 11 .

292 The Humble Advice of the Assembly of Divines, NOW by Authority OF Parliament Sitting at Westminster, Concerning a CONFession of Faith (London, Evan Tyler 1647), https://ia802700.us.archive.org/11/items/humbleadviceofas00west/humbleadviceofas00west.pdf [https://perma.cc/NV9M-H3X7] [hereinafter WeSTMINSTER CONFESSION].

293 See The Cambridge Platform of Church Discipline, Adopted in 1648, and the CONFEssion of Faith, AdOPTED in 1680, at 90-91 (Boston, Congregational Bd. of Publ'n 1855), https://ia802300.us.archive.org/3/items/cambridgeplatfo00goog/cambridgeplatfo00goog.pdf [https://perma.cc/H358-57RP].

294 WeSTMINSTER CONFESSION, supra note 292, ch. I, § I, at 1. For other traces of natural religion, see id. ch. IV, $\$ 2$, at 9 (describing how God created human beings "with reasonable and immortal souls ... after his own Image.”); ch. XXI, § I, at 37 (arguing that "the light of Nature" shows that God exists, that he is good, and that he is to be worshipped and served). For a brief discussion of the role of natural theology in John Calvin's own thought, see Russell Re Manning, Protestant Perspectives on Natural Theology, in Oxford HANDBOoK, supra note 272, at 201-04.

295 WestMinSTER CONFESSION, supra note 292, ch. VI, at 12-13.

$296 \quad$ See id. ch. X, at 21-22.
} 
knowledge of God must be sought through the revelation that he made in the Holy Scriptures. ${ }^{297}$ In these ways, reason and natural theology did play a role in New England Puritan theology, but a role that was firmly subordinate to that of faith and revelation. ${ }^{298}$

By the middle of the eighteenth century, the old Calvinist consensus was breaking down. Some theologians began to take a more rationalist approach to religion. One of the best known figures was the Rev. Jonathan Mayhew, the pastor of Boston's West Church. ${ }^{299}$ In a series of sermons delivered in 1748, Mayhew maintained that "the dignity of our nature" is founded upon our intellectual capacities: "It is principally on account of our reason, that we are said to have been created in the image of God." ${ }^{300}$ Like Clarke, Mayhew holds that morality consists of objective truths that arise from "the nature of God, [and] our relation to him, and one another." ${ }^{301}$ Mayhew also follows the Scottish Enlightenment philosophers in contending that humans have " $a$ moral sense" that leads them to feel pleasure from seeing good actions and pain from bad ones. ${ }^{302}$ He concedes that "our rational faculties [are] limited, [and so] there is room for our being instructed by revelation." "303 But he forcefully rejects the position that our minds are so darkened by the Fall that we are incapable of discerning religious and moral truths. ${ }^{304}$

Because Mayhew regards revelation as essential to Christianity, he cannot accept Tindal's view that it is merely "a re-publication of the law of nature." As Mayhew makes clear, however, he sees natural religion as lying at the core of Christianity. The most important duties of the Christian religion are the same as those "dictated by the light of nature": they "are natural moral duties




[that are] inforced with revealed and supernatural motives." ${ }^{306}$ He concludes that although "[m] odes and ceremonies of religion" may differ, "the substance of true religion must necessarily be the same ... in all countries, to all rational creatures, in all parts of the universe, in all periods of time. ${ }^{\$ 307}$

Mayhew also sees an integral connection between the concept of natural religion and "right of private judgment," or "freedom of thought and inquiry in religious matters." 300 The Westminster Confession had declared that Christians were entitled to "Liberty of Conscience," but it justified that liberty largely on the ground that "God alone is Lord of the Conscience, and hath left it free from the Doctrines and Commandments of men, which are in any thing contrary to his Word. ${ }^{\$ 09}$ Consistent with this limitation, the Confession held that both the church and the civil magistrate had authority to restrain the "publishing of such Opinions ... as are contrary to the light of Nature, or to the known principles of Christianity."

By contrast, Mayhew's defense of private judgment is based squarely on reason and natural religion. The freedom to judge for ourselves in religious matters and "to worship God according to our consciences" is rooted in our very nature as rational beings. ${ }^{311}$ This freedom "is absolutely unalienable in its own nature," because it is not only a right but also an "indispensable duty" which is enjoined by "God and nature and the gospel of Christ." ${ }^{312}$ Those who institute "human tests of orthodoxy" and "punish dissenters" invade "the natural rights of mankind" and act "in opposition to [the authority] of almighty God." "${ }^{13}$ Jesus and his followers were themselves "dissenters from the established religion" of the time. ${ }^{314}$ Indeed, the very idea of "articles of faith

\footnotetext{
${ }^{306} \quad I d$.

${ }^{307} \quad I d$

${ }^{308} \quad$ Id., Sermon III, at 42, 57.

${ }^{309}$ WeSTMinSTER CONFESSION, supra note 292, ch. XX, § II, at 35.

310 Id. $\$ \mathrm{IV}$, at 36 .

311 MaYhew, Sermon IV, in Seven Sermons, supra note 300, at 86; see also id., Sermon III, at 4647.

Id., Sermon IV, at 86.

Id., Sermon III, at 57-63.

Id., Sermon $I V$, at 83.
} 
established by law" is no less absurd than that of "mathematicks established by law. ${ }^{{ }^{315}}$

Although Mayhew and other liberal theologians were the foremost advocates of the idea of natural religion among New England Congregationalists at this time, they were not alone. The idea also played a vital role in works of the other two major schools of Congregationalist thought: traditional Calvinism and the New Divinity of the followers of Jonathan Edwards. ${ }^{316}$ The former category included Peter Clark's sermon on Man's Dignity and Duty as a Reasonable Creature, while the latter included Nathanael Emmons's discourse on The Dignity of Man. ${ }^{317}$ To be sure, there were important differences between these three authors: Clark placed a greater emphasis on the insufficiency of reason and the need for revelation than did Mayhew or Emmons. ${ }^{318}$ But each of them stressed the importance of reason and its harmony with revelation. These themes were also central to the Dudleian lectures on natural religion that were delivered at Harvard College beginning in the $1750 \mathrm{~s}$, and that were given by Congregationalists of different persuasions. $^{319}$

Id. at 84 .

See Holifield, supra note 12, at 128 (discussing these three views).

Peter Clark, Man's Dignity and Duty as a Reasonable Creature; and His InSUfFiciency as a Fallen CREATURe (Boston, Richard \& Samuel Draper 1763), http://name.umdl.umich.edu/N07331.0001.001 [https://perma.cc/7VX2-KE23]; NATHANAEL Emmons, The Dignity of Man (1787), reprinted in 1 Political Sermons, supra note 105, at 883.

318 See ClaRK, supra note 317, at 26-33.

319 Endowed by a bequest from the prominent judge Paul Dudley, these lectures were modeled on the Boyle lectures in England, see supra text accompanying note 281, and were devoted to natural and revealed religion as well as other topics. For studies, see LEE, supra note 15, ch. 3; Leslee K. Gilbert, The Altar of Liberty: Enlightened Dissent and the Dudleian Lectures, 1755-1765, 31 HIST. J. MAss. (Summer 2003), http://www.westfield.ma.edu/historical-journal/wp-content/uploads/2018/06/gilbertsummer-2003-combined.pdf [https://perma.cc/2ECY-4BK2]. The Dudleian lectures are still being given over 250 years later. For a comprehensive list, see Dudleian Lectures, ANDOvEr-Harv. THEOLOGICAL LiBR., https:/guides.library.harvard.edu/hds/named-lecture-series/dudleian [https://perma.cc/HB5G-Z9VP]. 


\section{E. Natural Science}

It is "a commonplace" among historians that "natural religion took enormous support from the developments in seventeenth century science." ${ }^{220}$ Here I shall sketch the position of Sir Isaac Newton, the most celebrated scientist of the age..$^{321}$ A summary of his views can be found in key passages of the Principia and Opticks. ${ }^{322}$ According to Newton, "Natural Philosophy" or science proceeds inductively by observing phenomena and then proceeding "from Effects to their Causes, and from particular Causes to more general ones," until it reaches the first cause from which all things began. ${ }^{323}$ When we observe "It]his most beautiful System of the Sun, Planets and Comets," we recognize that it could not have come about through "mere mechanical causes," but only "from the counsel and dominion of an intelligent and powerful being.", ${ }^{24}$ This being, whom we call God, is "Eternal and Infinite, Omnipotent and Omniscient., ${ }^{325}$ "[B]y existing always and every where," he constitutes time and space. ${ }^{326}$ In the beginning, he created matter and established the "general Laws of Nature" such as gravitation. ${ }^{327}$ His creative intelligence and choice can be seen in natural phenomena ranging from the

${ }^{320}$ G.A.J. Rogers, Nature, Man and God in the English Enlightenment, in RELIGION, REASON AND NATURE In EARLY MODERn EuROPE 152 (Robert Crocker ed., 2001).

${ }^{321}$ For valuable discussions of religion in Newton's thought, see ROB IlIFFe, PrIEST OF NATURE: THE Religious Worlds of Isaac Newton (2017); Robert Iliffe, Newton's Religious Life and Work (2013), http://www.newtonproject.ox.ac.uk/view/texts/normalized/CNTX00001 [https://perm a.cc/5KCC-USL2]; Rogers, supra note 320, at 152-56.

322 IsaAC Newton, General Scholium, in The Mathematical

Principles OF NATURAL Philosophy 387, 387-93 (London, 1729), http://www.newtonproject.o x.ac.uk/view/texts/normalized/NATP00056 [https://perma.cc/JKF3-HFZV] [hereinafter NEWTON, Principles]; ISAaC Newton, The Third Book of Opticks, in OPTICKS (London, W. \&J. Innys, 2d ed. 1718) (1704), http://www.newtonproject.ox.ac.uk/view/texts/normalized/NATP00 051 [https://perma.cc/93NA-GCNF] [hereinafter NEwTON, OpTICKs]. My citations are to the website of Oxford University's Newton Project, which is producing a definitive edition of his works.

323 NewTOn, Opticks, supra note 322, at 380-81.

324 NeWTON, PRINCIPLES, supra note 322, at 388-89.

I25. at 389 .

Id. at 390 .

${ }^{327} \quad$ NewTON, Opticks, supra note 322, at 375-78. 
solar system to "the Bodies of Animals." ${ }^{228}$ He perceives, understands, and "governs all things" through his "providence."

For Newton, these conclusions of scientific inquiry have vital implications for "moral Philosophy":

For so far as we can know by natural Philosophy [i.e., science] what is the first Cause, what Power he has over us, and what Benefits we receive from him, so far our Duty towards him, as well as that towards one another, will appear to us by the Light of Nature. ${ }^{330}$

In an unpublished manuscript, Newton expanded on this concept of "natural religion." ${ }^{331}$ In addition to requiring individuals "to give thanks \& honour \& glory" to God for their existence and well-being, this religion enjoined them to love their neighbors as themselves. ${ }^{332}$ This "moral part of religion" was of "an eternal immutable nature"; it was "binding to all nations" at all times and lay at the core of both Judaism and Christianity.

Thus, Newton did not view science as merely compatible with religion. Instead, as Rob Iliffe has explained, "he believed that natural philosophy was to a large extent a religious enterprise through which one could come to an understanding of the way God had created the world." ${ }^{334}$ For Newton, science laid the foundation for a rational approach to religion. ${ }^{335}$ At the same time, he accepted the legitimacy of revelation and sought to use reason to determine the true meaning of Scripture. ${ }^{336}$ In line with this devotion to reason, he was strongly committed to liberty of conscience and freedom of inquiry.

Id. at 378.

329 NeWTON, PRINCIPLES, supra note 322, at 389-91.

NeWTON, Opticks, supra note 322, at 381.

ası Isaac Newton, Of the Religion of the Iews \& Christians 1r (n.d.), http://www.newtonproject.ox.ac.uk/view/texts/normalized/THEM00351 [https://perma.cc/B9KZ$3428]$.

332 Id.

Iaz. at 1r-1v; see also Isaac Newton, Irenicum, or Ecclesiastical Polyty Tending to Peace 35 (n.d.), http://www.newtonproject.ox.ac.uk/view/texts/normalized/THEM00003 [https://perma.cc/A855WYJ8].

Is4 ILFFE, supra note 321, at 16.

335 See id. at 19-21.

326 See id. at 16, 20-21.

337 See id. at 17-19. For accounts of Newtonianism and natural theology in the eighteenth century, see JONATHAN ISRAEL, ENLIGHTENMENT CONTESTED 201 -222 (2006); JEFFREY R. WIGELSWORTH, Deism in Enlightenment england: Theology, Politics, and Newtonian Public SCIENCE (2009). 


\section{F. The Radical Whig Tradition}

Finally, a commitment to rational religion and the rights of conscience was integral to the Commonwealth or Real Whig tradition-a body of eighteenthcentury thought that identified with the struggles against the Stuarts that culminated in the overthrow of Charles I in the Civil War and of James II in the Glorious Revolution of 1688. ${ }^{338}$ As Caroline Robbins explains in her classic study, The Eighteenth-Century Commonwealthman, this tradition encompassed politicians, clergymen, and lawyers; popular writers and academics; Deists, Protestant dissenters, and liberal Anglicans. ${ }^{339}$ It included Hutcheson, Mayhew, Price, and Priestley and drew inspiration from Locke, Newton, Tillotson, and Clarke. ${ }^{310}$ In these ways, the Radical Whig tradition combined the various strands of thought that we have canvassed in this Part. As Bernard Bailyn and Gordon S. Wood demonstrate, although this tradition had a limited following in Great Britain and Ireland, it deeply shaped the beliefs of colonial Americans and provided the ideological origins of the American Revolution. ${ }^{341}$

The eighteenth-century Commonwealthmen defended what they regarded as the traditional rights of British subjects and the natural rights of mankind. ${ }^{342}$ They advocated for freedom of thought and expression; constitutional government in which the people were adequately represented; education that reflected modern philosophy and science; the promotion of moral and civic virtue; and a limited measure of social equality. ${ }^{3+3}$ They were also committed to the protection of religious liberty as an inalienable right. ${ }^{34}$ This position had been advocated by the Levellers during the Commonwealth period ${ }^{315}$ and

See Caroline Robbins, The Eighteenth-Century Commonwealthman (Atheneum 1968) (1959).

$339 \quad$ See id. at 3-21.

340 See id. at $3-21,76$

31 BAILYN, supra note 106; GORDON S. WOOD, THE CreATION OF THE AMERICAN REPUBLIC 1776 1787 (2d ed. 1998)

32 See Robins, supra note 338, at 7-8.

33 See id. at 5-14.

${ }^{34} \quad$ See id. at 8-12, 115, 160-71, 236, 328-30.

3.5 See John Marshall, John Locke, Toleration and Early Enlightenment Culture 329 (2006). 
further developed by Protestant dissenters during the Restoration. ${ }^{316}$ At that time, the dissenters were subjected to severe persecution ${ }^{347}$ as well as to harsh attacks from some leaders of the re-established Church of England, who argued that the corruption of human nature after the Fall made individuals incapable of properly using their own judgment in religious matters. ${ }^{318}$ As Richard Ashcraft explains, the dissenters responded that this position in effect denied that humans were reasonable creatures. ${ }^{399}$ By contrast, the dissenters

presented a picture of rational individuals having been created in a state of equality and freedom.... These individuals constituted a natural moral community, since they existed under an established framework of moral obligations owed to each other and to God. Through the use of their reason, they were capable of discovering these obligations embodied in the Law of Nature. This law not only imposed duties, but it also confirmed the rights of individuals, among which ... was the right to follow the dictates of one's conscience. $^{3.50}$

This position became the standard Radical Whig view. A good example may be found in the essays of John Trenchard and Thomas Gordon that appeared in The Independent Whig and Cato's Letters, works that were widely known in eighteenth-century Britain and America. ${ }^{351}$ According to Trenchard and Gordon, human beings are said to be created in God's image because they are endowed with reason..$^{352}$ By using this faculty, they discover that there is "a First Cause" that made and preserves all things, and they learn

si See Richard Ashcraft, Revolutionary Politics \& Locke's Two Treatises of GOVERNMENT 51-62 (1986).

37 See John Coffey, Persecution and Toleration in Protestant England, 1558-1689, at 167-79 (2000).

3 See ASHCRAFT, supra note 346 , at 52-53.

39 See id. at 52.

30 Id. at 66-67.

3 John Trenchard \& ThOmas Gordon, The IndePENDENT Whig (London, J. Peele, 7th ed. 1743), https://oll.libertyfund.org/titles/gordon-the-independent-whig-4-vols-1720-1743 [hereinafter Independent Whig]; John Trenchard \& Thomas Gordon, Cato's LetTers (Ronald Hamowy ed., Liberty Fund 1995) (6th ed. 1755), https://oll.libertyfund.org/titles/trenchard-catosletters-4-vols-in-2-lf-ed [hereinafter CATO's LeTters]. Permanent citations for the Independent Whig may be found at the following locations: volume 1, https://perma.cc/XST5-GHTF; volume 2, https://perma.cc/543Z-BHN3. Permanent citations for Cato's Letters may be found here: volume 2, https://perma.cc/AZC9-X9BP; volume 3 , https://perma.cc/2C2S-A9BH; volume 4, https://perma.cc/L2JC-83X6.

2 INDEPENDENT WHIG, supra note 351, NO. XXXV, at 24, 26-27. 
their "Duty in relation to God" and to "one another." "3s These duties of morality constitute "Natural Religion," which aims to "promotell unlimited and universal Happiness to the whole World., ${ }^{{ }^{334}}$

For Trenchard and Gordon, our intellectual capacities are also vital for responding to revelation, which "presupposes Reason, and addresses itself to Reason. ${ }^{\text {\$55 }}$ Only reason can determine whether the Scriptures are the Word of God and how they should be interpreted. ${ }^{356}$ Nor is it possible to make new converts other than by "an Appeal to their Reason, by which they are to judge for themselves of the Reasonableness of our Religion."

Up to this point, Trenchard and Gordon express views that would be accepted by every rationalist Christian. In some essays, they go further and maintain that Christianity is essentially "natural Religion restored and improved," and that it contains nothing that is "mysterious" or "above reason.” " 38 In this respect, they side with Christian Deists like Tindal and Toland and against other rationalist Christians like Locke and Clarke. ${ }^{359}$ They also differ with Locke in that they accept the idea of an established church, although they reject the notion that civil offices should be reserved for its members. ${ }^{360}$ In common with all Radical Whigs, however, Trenchard and Gordon hold that the "Devotion which [God] requires must be free, rational, and willing," ${ }^{361}$ and they condemn all forms of persecution-a practice that is "incompatible with true Religion, whether Natural or Revealed," invades the core of human liberty by infringing the inherent "right of every

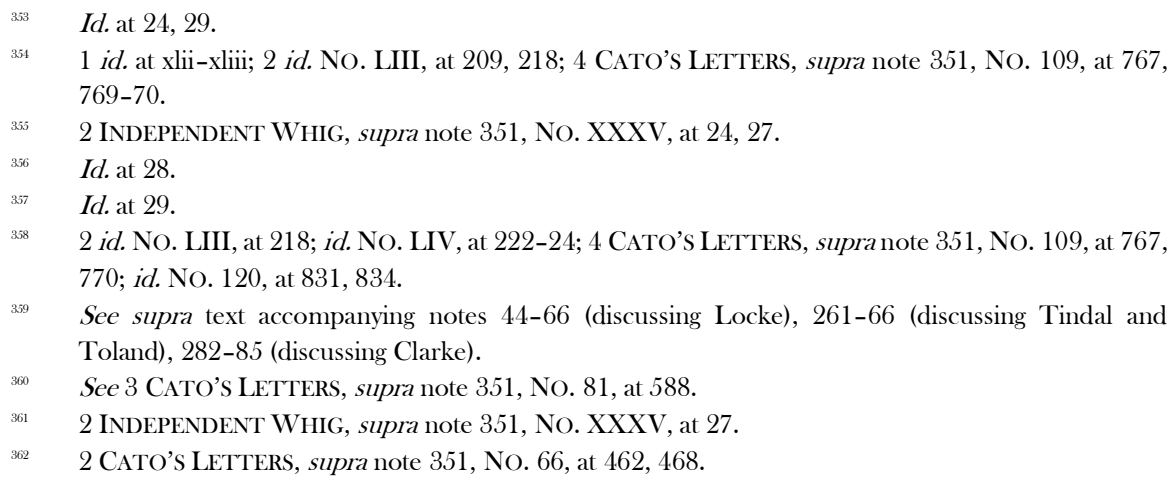


man to pursue the natural, reasonable, and religious dictates of his own mind." ${ }^{963}$

\section{G. Conclusion}

Parts I and II have explored the place of natural religion, natural law, and natural rights in the intellectual world of eighteenth-century Americans. These ideas held that humans are capable of using reason to discern the principles that govern the natural and moral realms, including the duties that they owe to God and one another. This conception of reason provided a foundation for religious belief as well as religious liberty. This set of ideas was present in one form or another in the natural law theories of Locke and Pufendorf, the English jurisprudence of Blackstone and Mansfield, the moral philosophy of Hutcheson and Price, the works of theologians from Herbert to Mayhew, the natural science of Newton, and the Radical Whig tradition of Trenchard and Gordon. In the rest of this Article, I show how this account of natural religion and related ideas can help us to understand what Americans in the founding era meant when they incorporated protections for religious freedom into the state and federal constitutions.

\section{THE AMERICAN REvOluTION AND THE FIRST STATE CONSTITUTIONS}

\section{A. The Revolution}

In late 1772, a public meeting in Boston issued a statement to the people of Massachusetts. ${ }^{364}$ As Gordon Wood explains, this statement-which became known as the Boston pamphlet-"was one of the most important in [this] period" because of the powerful manner in which it articulated the

Id. NO. 59, at 405, 406-07; id. No. 60, at 413, 414; id. NO. 62 , at 426, 428-29; 1 INDEPENDENT WHIG, supra note 351, No. XXII, at 188, 190; id. No. XXIV, at 207.

36 The Votes and Proceedings of the Freeholders and Other Inhabitants of the TOWn of Boston (1772), in 1 The American Revolution: Writings From the PAMPHLET DEBATE 759 (Gordon S. Wood ed., 2015). 
colonists' ideology and inspired the growing resistance to Great Britain. ${ }^{365}$ The pamphlet began with an account of the "Natural Rights of the Colonists as Men" that was drawn from Locke. ${ }^{366}$ In addition to life, liberty, and property, the Bostonians declared that "by the eternal and immutable Laws of GOD and Nature" everyone "has a Right peaceably and quietly to worship God, according to the Dictates of his Conscience." ${ }^{367}$ As Locke's Letters on Toleration demonstrated, this "Spirit of Toleration" was also "the chief charactistical Mark of the true Church." " Rights of the Colonists as Christians," the pamphlet maintained that this inherent right to religious liberty had been "restored" to "every Subject in England" by the Toleration Act of $1689 .^{369}$ After enumerating a long list of other grievances against the British government, the Bostonians recounted that their ancestors had come to the new world to escape the "cruel persecutlion of] all who differed from the established Church," and went on to express concern about the efforts that were then being made to extend the Anglican hierarchy's power to America-a development that would endanger "that Liberty with which CHRIST hath made us free." ${ }^{370}$ In these ways, the Bostonians advanced an argument for religious liberty that was rooted in both natural religion and Protestant Christianity.

In this litany of "rights and grievances," the Boston pamphlet "anticipate[d] the Declaration of Independence." ${ }^{371}$ Of course, that Declaration also embodies the ideas we have discussed. Jefferson bases the American case for independence on "the Laws of Nature and of Nature's God" ${ }^{372}$-terms that often appear in accounts of natural religion. ${ }^{373}$ The idea that human beings

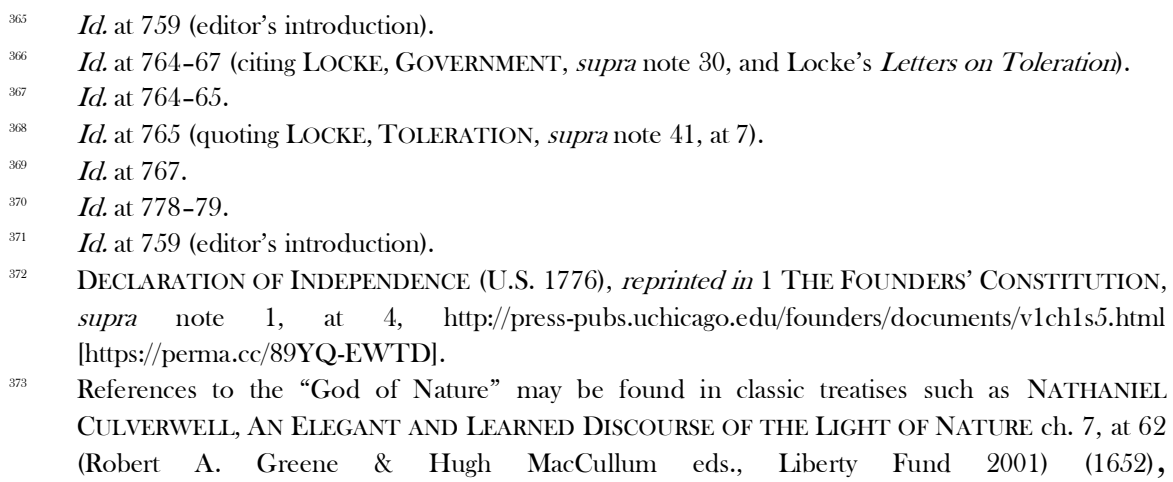


"are endowed by their Creator with certain unalienable Rights" also sounds in natural religion and can be found in various forms in Locke, Hutcheson, and others in the Radical Whig tradition. ${ }^{374}$ Finally, the Americans' concluding "appeal[lto the Supreme Judge of the world for the rectitude of our intentions" ${ }^{275}$ recalls Locke's discussion of the rights of resistance and revolution in the Second Treatise, where he explains that when the people become convinced that the government has become oppressive, they have no alternative but to defend their rights by force, while "appeal/ingl to Heaven" for the justice of their cause. ${ }^{376}$

\section{B. The First State Constitutions and Declarations of Rights}

\section{Virginia}

On the eve of independence, representatives of the people of Virginia met in convention to establish a constitutional framework for their new state. The Declaration of Rights, which was drafted by George Mason, began by proclaiming that

all men are by nature equally free and independent, and have certain inherent rights, of which, when they enter into a state of society, they cannot, by any compact, deprive or divest their posterity; namely, the enjoyment of life and liberty, with the means of acquiring and possessing property, and pursuing and obtaining happiness and safety. ${ }^{377}$

https://oll.libertyfund.org/titles/culverwell-an-elegant-and-learned-discourse-of-the-light-of-nature [https://perma.cc/L2H9-LB3S]; RichaRd HOOKER, OF THE LAWS OF ECClesiastical POLITY bk. I, ch. 3, § 4, at 62 (Arthur Stephen McGrade ed., Cambridge Univ. Press 1989); and 1 HuTCHESON, System, supra note 194, bk. II, ch. 3, § VII, at 265; as well as in Dudleian lectures such as Clark, supra note 317 , at 13 , and Ebenezer Gay, Natural Religion, as Distinguish'D FROM REveAled 10 (Boston, John Draper 1759), http://name.umdl.umich.edu/N06583.0001.001 [https://perma.cc/4UX3-NYD2].

${ }^{374}$ See, e.g., LOCKe, GOVERNMENT, supra note 30, bk. II, $\$ 6$, at 271 (attributing rights of life, liberty, and property to creation by God); 1 Hutcheson, SYSTEM, supra note 194, bk. II, ch. 5, at $293-$ 304 (discussing rights that are secured to individuals "by all the laws of God and nature") (quotation at 299).

375 DECLARATION OF INDEPENDENCE, supra note 372.

376 LOCKe, GOVERNMENT, supra note 30, bk. II, \$§ 168, 242, at 379-80, 427.

37 VA. DeClaration OF Rights, supra note 1 , art. 1. 
After articulating many other principles of Radical Whig ideology, the Declaration turned to religion. In Mason's draft, the sixteenth and final article asserted that

Religion, or the Duty which we owe to our divine and omnipotent Creator, and the Manner of discharging it, can be governed only by Reason and Conviction, not by Force or Violence; and therefore that all Men shou'd enjoy the fullest Toleration in the Exercise of Religion, according to the Dictates of Conscience, unpunished and unrestrained by the Magistrate, unless, under Colour of Religion, any Man disturb the Peace, the Happiness, or Safety of Society, or of Individuals. And that it is the mutual Duty of all, to practice Christian Forbearance, Love and Charity towards Each other. ${ }^{378}$

In both phraseology and substance, this draft clearly owes much to Locke's Letters on Toleration. The last sentence echoes his contention that "Charity" enjoins "the mutual Toleration of Christians in their different Professions of Religion." ${ }^{379}$ Like Locke, however, this draft does not limit toleration to Christians but extends it to "all Men" as beings endowed with "Reason." "380 To express this point in the words of article 1, religious liberty is one of the "inherent rights" that all individuals possess "by nature" and that they do not abandon when they enter civil society. ${ }^{381}$ This point was made even clearer when the convention adopted James Madison's proposal to amend Mason's language to speak in terms of rights rather than of "Toleration." form, article 16 read:

That Religion, or the duty which we owe to our Creator, and the manner of discharging it, can be directed only by reason and conviction, not by force or violence; and, therefore, all men are equally entitled to the free exercise of religion, according to the dictates of conscience; and that it is the mutual duty of all to practise Christian forbearance, love, and charity, towards each other. ${ }^{333}$

Finally, we should observe that this provision bases religious liberty on the core idea of natural religion: that "Religion ... can be directed only by reason and conviction." Of course, that does not mean that the provision was intended to denigrate revealed religion in any way; the concluding reference

${ }^{378}$ George Mason's Proposed Declaration of Rights, [ca. 20-25 May 1776], NAT'L ARCHIVES: FOUNDERS ONLINE, https://founders.archives.gov/documents/Madison/01-01-02-0054-0001 [https://perma.cc/X53Y-HKP3].

379 LOCKe, TOLERATION, supra note 41 , at 7-12.

${ }^{380}$ See supra text accompanying notes 72, 80-89.

381 VA. DEClaRATION OF Rights, supra note 1, art. 1.

382 See BUCKLEY, VIRGINIA, supra note 6, at 18.

383 VA. DECLARATION OF RigHTS, supra note 1, art. 16, at 3-4. 
to Christianity suffices to make that clear. But it is equally clear that the Convention's basic assertion is that individuals must be free from compulsion regarding religion because it inherently involves the use of reason to discern one's duties to God.

Article 16 condemned the legal penalties and restrictions that had often been imposed on dissenters from Anglicanism, which was the established religion of the colony. Another amendment that Madison drafted would have had the effect of abolishing the establishment altogether. ${ }^{384}$ Although this effort failed in 1776, it succeeded a decade later when he secured the passage of Jefferson's Bill for Establishing Religious Freedom-a development that, as Part IV will show, also was based on ideas of natural rights and natural religion.

\section{Pennsylvania}

Unlike Virginia, the Pennsylvania colony gave religious liberty broad protection from the beginning. The rationale for this approach can be found in The Great Case of Liberty of Conscience and other writings by its founder, the Quaker William Penn. ${ }^{385}$ Some of Penn's arguments were based on "the Authority of ... Scripture," such as the contention that religious persecution violated biblical teachings by "enthron[ingl Man [rather than God] as King over Conscience." ${ }^{386}$ Other arguments were based on "the Authority of Reason." Penn maintained that individuals have an innate "Instinct of a Deity" which is essential to their very nature. ${ }^{388}$ Efforts to restrict their religious liberty are "destructive of the great Priviledge of Nature and Principle of Reason," for "[t]he Understanding can never be convinc'd" by "any external Violence," but only "by such Arguments, as are Rational, Perswasive, and

See BuCKLEY, VIRGINIA, supra note 6, at 18-19.

saj William Penn, The Great Case of Liberty of Conscience (1670), reprinted in The Political Writings of William Penn 79 (Andrew R. Murphy ed., 2002), https://oll.libertyfund.org/titles/penn-the-political-writings-of-william-penn [https://perma.cc/99AA32DC]. On Penn, see Andrew R. Murphy, Liberty, Conscience, and Toleration: The Political Thought of William Penn (2016).

386 PENN, supra note 385 , at 79, 86-87.

${ }_{387} \quad I d$. at 79. On Penn's use of natural theology, see Miller, supra note 10, at 56-60.

sse PENN, supra note 385 , at 92. 
suitable to its own Nature." ${ }^{399}$ It follows that "Liberty of Conscience is every Man's natural Right." ${ }^{390}$

A similar fusion of rationalist and Christian justifications can be found in the first chapter of the Great Law that was enacted by Penn and the colonial assembly in 1682. ${ }^{391}$ This law guaranteed religious freedom to all believers in God on the ground that he alone was "Lord of Conscience Father of Lights \& Spirits an[d] the Author as well as Object of all divine Knowledge Faith and Worship who only can Enlighten the Mind and perswade and Convince the Understanding of People." ${ }^{\text {"992 }}$ As J. William Frost observes, this provision was drafted in such a way that Quakers could interpret "enlightening the mind and convincing the understanding as referring to the experience of the Inward Light of Christ," while Anglicans and Deists could interpret it in more rationalist terms. ${ }^{393}$ At the same time, the Great Law reserved civil officeholding to Christians. ${ }^{394}$ Yet in contrast to the Anglican establishments in the southern colonies and the Congregationalist establishments in New England, Pennsylvania and its sister mid-Atlantic colonies established no church. ${ }^{395}$ For these reasons, they came to be seen as bastions of religious liberty and diversity. ${ }^{396}$

This libertarian approach was embodied in the new state constitution that was adopted by a convention in September $1776 .{ }^{397}$ That document draws on the language of natural religion and Radical Whig political theory. It opens by declaring that "all government ought to be instituted ... for the security and protection of the community as such, and to enable the individuals who compose it to enjoy their natural rights, and the other blessings which the

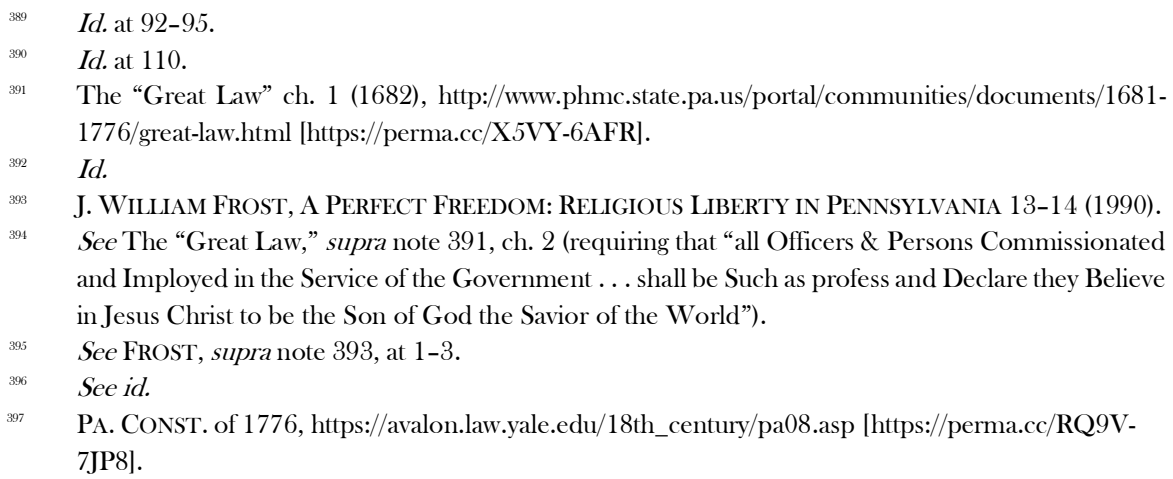


Author of existence has bestowed upon man," and by thanking him for permitting the people to deliberately and consensually adopt rules for their own governance. ${ }^{398}$ The Constitution then sets forth a Declaration of Rights. After affirming the inherent liberty and equality of mankind, it asserts:

That all men have a natural and unalienable right to worship Almighty God according to the dictates of their own consciences and understanding: And that no man ought or of right can be compelled to attend any religious worship, or erect or support any place of worship, or maintain any ministry, contrary to, or against, his own free will and consent: Nor can any man, who acknowledges the being of a God, be justly deprived or abridged of any civil right as a citizen, on account of his religious sentiments or peculiar mode of religious worship: And that no authority can or ought to be vested in, or assumed by any power whatever, that shall in any case interfere with, or in any manner controul, the right of conscience in the free exercise of religious worship. ${ }^{399}$

As for the right to hold civil office, the convention initially proposed to extend it to everyone who acknowledged the being of a God and a future state of rewards and punishments. ${ }^{400}$ After this proposal encountered opposition from the Philadelphia clergy, it was amended to restrict office holding to Christians. ${ }^{401}$ But the state reverted to the convention's original view when a new Constitution was adopted in $1790 .^{402}$

\section{Massachusetts}

Perhaps the most fully developed exposition of Radical Whig ideology in the first state constitutions may be found in the one that was drafted by John Adams and adopted by Massachusetts in $1780 .{ }^{403}$ The preamble characterizes the body politic as a "social compact" which the people make to protect "their

Id. pmbl.

Id. arts. I-II.

400 $\quad$ Frost, supra note 393, at 65.

${ }^{401}$ See id.; PA. CONST. of 1776, supra note 397, ch. II, \$ 10.

402 See Frost, supra note 393 , at $74-75$; PA. CONST. of 1790 , art. IX, $\$ 4$, https://www.paconstitution.org/texts-of-the-constitution/1790-2/ [https://perma.cc/5PDN-LSAH] (stating that a person who "acknowledges the being of God and a future state of rewards and punishments" shall not be disqualified from holding office). The new Constitution's protection for the "natural and indefeasible right" to religious liberty appears in $i d . \$ 3$.

${ }_{403}$ Mass. CONST. of 1780, in 1 ThE FOUNDERS' CONSTITUTION, supra note 1, at 11-23, https://presspubs.uchicago.edu/founders/print_documents/v1ch1s6.html [https://perma.cc/5JRW-2D4F]. 
natural rights" and to promote "their safety, prosperity and happiness." ${ }^{04}$ After thanking "the Great Legislator of the Universe" for the opportunity to establish this compact, the document gives a comprehensive account of the fundamental rights of individuals and the community as a whole. ${ }^{405}$ Like its counterparts in Virginia and Pennsylvania, the Massachusetts convention describes religious liberty in accord with ideas of natural rights and natural religion. Article II of the Declaration of Rights asserts that "[i]t is the right as well as the duty of all men in society, publicly, and at stated seasons, to worship the SUPREME BEING, the great creator and preserver of the universe." For this reason, "no subject shall be hurt, molested, or restrained, in his person, liberty, or estate, for worshipping GOD in the manner and season most agreeable to the dictates of his own conscience; or for his religious profession or sentiments," so long as he does not "disturb the public peace, or obstruct others in their religious worship." ${ }^{077}$

Although this provision was uncontroversial, that was not true of the next one, which reflected the state's Puritan heritage. From the founding of the Massachusetts Bay Colony, Congregationalism had effectively been the established religion. ${ }^{408}$ The 1780 Constitution modified this position but did not eradicate it. As Article III explained, "the happiness of a people, and the good order and preservation of civil government, essentially depend upon piety, religion and morality," which could be maintained only by means of public worship and religious instruction. ${ }^{409}$ The towns therefore should be required to provide "for the institution of the public worship of GOD, and for the support and maintenance of public protestant teachers of piety, religion and morality" to be elected by the people of each town. ${ }^{410}$ All individuals should be required to attend the instruction of such teachers or ministers if they could "conscientiously and conveniently" do so. ${ }^{411}$ This public teaching

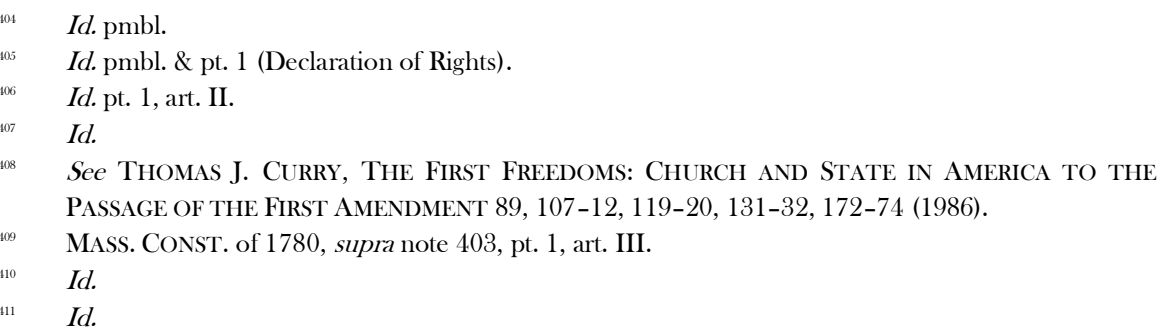


and worship was to be supported by taxation, although each individual would have the right to require that the money he paid be "applied to the support of the public teacher or teachers of his own religious sect or denomination, provided there be any on whose instructions he attends." ${ }^{\prime \prime 2}$

Although this framework theoretically allowed towns to elect ministers from any Christian denomination, most towns were likely to choose Congregationalists. ${ }^{43}$ In addition, while individuals had a right to direct their taxes to their own denominations, they sometimes encountered legal and practical obstacles to doing so. ${ }^{414}$ Moreover, some denominations, such as Baptists, held beliefs that forbade them to accept coerced payments. ${ }^{415}$ The upshot was that Article III was likely to maintain the dominance of the Congregational churches. The provision was vigorously opposed by Baptists and others as an infringement of religious liberty, but it was ratified by the towns (in a disputed vote count) and became part of the Declaration of Rights. ${ }^{416}$

\section{Conclusion}

Although the Revolutionary-era state constitutions took a range of positions on the relation between religion and state, they were nearly unanimous on one point: that all individuals have a natural and inalienable right to form their own religious beliefs and to worship God in accord with their own "reason," “conviction," "conscience," and "understanding”" ${ }^{417}$-ideas

$12 \quad I d$.

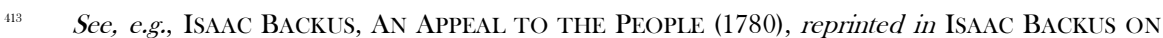
Church, State, ANd Calvinism: Pamphlets, 1754-1789, at 386-87 (William G. McLoughlin ed., 1968) (editor's introduction) [hereinafter BACKUS PAMPHLETS].

stu See id. at 387.

4 See id. at 392.

416 See William G. MCloughlin, IsaAc Backus and the American Pietistic Tradition 14457 (1967).

417 Del. Declaration of Rights of $1776, \$ 2$, reprinted in The Founders' Constitution, supra note 1, Bill of Rights, document 4, at 5, http://press-pubs.uchicago.edu/founders/documents/bill_of _rightss4.html [https://perma.cc/6JZD-N2U2] ("[A]ll men have a natural and unalienable right to worship Almighty God according to the dictates of their own consciences and understandings.”); GA. CONST. of 1777, art. LVI, https://avalon.law.yale.edu/18th_century/ga02.asp [https://perma.cc/X7NC-W3S2] ("All persons whatever shall have the free exercise of their religion; provided it be not repugnant to the peace and safety of the State; and shall not, unless by consent, 
support any teacher or teachers except those of their own profession.”); GA. CONST. of 1789, art. IV, § 5, https://georgiainfo.galileo.usg.edu/topics/government/related_article/constitutions/georgiaconstitution-of-1789 [https://perma.cc/7GZU-GSQZ] ("All persons shall have the free exercise of religion, without being obliged to contribute to the support of any religious profession but their own.”); MASS. CONST. of 1780, supra note 403, pt. 1, art. II, at 11 (describing religious liberty as "the right... of all men in society"); N.H. CONST. of 1784, pt. I, arts. IV-V, https://lonang.com/library/organic/1784-nhr/ [https://perma.cc/MYH8-234X] ("Every individual has a natural and unalienable right to worship GOD according to the dictates of his own conscience, and reason ...."); N.J. CONST. of 1776, art. XVIII, http://avalon.law.yale.edu/18th_century/nj15.asp [https://perma.cc/KR2B-CN32] ("[N]o person shall ever ... be deprived of the inestimable privilege of worshipping Almighty God in a manner, agreeable to the dictates of his own conscience ....”); N.Y. CONST. of 1777, art. XXXVIII, http://avalon.law.yale.edu/18th_century/ny01.asp [https://perma.cc/WZ94-XDVY] (declaring that "we are required, by the benevolent principles of rational liberty, not only to expel civil tyranny, but also to guard against . . spiritual oppression and intolerance," and providing "that the free exercise and enjoyment of religious profession and worship, without discrimination or preference, shall forever hereafter be allowed, within this State, to all mankind"); N.C. CONST. of 1776, A Declaration of Rights, § XIX, https://avalon.law.yale.edu/18th_century/nc07.asp [https://perma.cc/95DY-6RSW] (“[A]Il men have a natural and unalienable right to worship Almighty God according to the dictates of their own consciences."); PA. CONST. of 1776, , supra note 397, A Declaration of the Rights of the Inhabitants of the Commonwealth or State of Pennsylvania, art. II ("[A]ll men have a natural and unalienable right to worship Almighty God according to the dictates of their own consciences and understanding...."); VA. Declaration of Rights, supra note 1, art. 16, quoted supra text accompanying note 1 .

The clearest exception is the South Carolina Constitution of 1778, which confined toleration to those "persons and religious societies who acknowledge that there is one God, and a future state of rewards and punishments, and that God is publicly to be worshipped." S.C. CONST. of 1778, art. XXXVIII, https://avalon.law.yale.edu/18th_century/sc02.asp [https://perma.cc/SRP7-6QR5]. In 1790, however, the state acceded to the consensus by providing that " $[t]$ he free exercise and enjoyment of religious profession [and] worship, without discrimination or preference, shall forever hereafter be allowed within this State to all mankind.” S.C. CONST. of 1790, art. VIII, $\$ 1$, https://www.carolana.com/SC/Documents/sc_constitution_1790.html [https://perma.cc/K4UXHP5L].

Another arguable exception is the Maryland declaration, which provided that "all persons, professing the Christian religion, are equally entitled to protection in their religious liberty." MD. CONST. of 1776, A Declaration of Rights, \&c, art. XXXIII, https://avalon.law.yale.edu/17th_century/ma02.asp [https://perma.cc/X7ES-B7CR] (emphasis added). In virtually the same breath, however, the Declaration asserted that "it is the duty of every man to worship God in such manner as he thinks most acceptable to him" and that "no person ought by any law to be molested ... on account of his religious persuasion ... ; unless, under colour of religion, any man shall disturb the good order, peace or safety of the State, or shall infringe the laws of morality, or injure others, in their natural, civil, or religious rights." Id. (emphasis added). Thus, while hardly a model of clarity, the Maryland provision does not appear to have been meant to limit religious freedom to Christians or to have diverged from the prevailing view that this right belongs to all. 
that resonate with natural religion. Of course, this is not to deny the importance of revelation. Many people considered the teachings of reason and revelation to be in harmony with one another. But as this section has shown, when the state declarations granted protection to religious liberty, they primarily used the language of natural rights and reason rather than of explicitly Christian theology. One can offer several explanations for this choice. First, the question of religious toleration historically was controversial within Christianity, and that controversy had not ceased by the late eighteenth century. By adopting the language they did, the states were able to bypass such theological disputes. Second, the language of natural rights reflected the view that religious liberty is a right that belongs not only to Christians (with all the problems that would have been involved in determining who qualified and in excluding others) but to all human beings. And third, the use of such language allowed the declarations to ground the right to religious liberty in the same principles as the other rights that they protected, such as life, liberty, property, and freedom of speech.

Accordingly, the state constitutions treated religious liberty as a natural right of mankind. At the same time, many states limited civil equality or the right to hold office to Christians or even to Protestants, ${ }^{418}$ and some states also retained their religious establishments. ${ }^{419}$ As we have seen, contemporary theorists of natural religion were not of one mind concerning the idea of religious establishments-some like Locke and Price rejected this notion ${ }^{420}$ while others like Pufendorf, Hutcheson, and Witherspoon accepted it in some form. ${ }^{421}$ Yet there clearly is some tension between the idea that religious liberty

418 See, e.g., Del. DeClaRATION OF Rights OF 1776, supra note 417, 33 (guaranteeing "equal rights and privileges" to "all persons professing the Christian religion"); MASS. CONST. OF 1780, supra note 403, pt. I, art. III, at 12 (establishing a system of public teaching and worship and providing that "every denomination of christians, demeaning themselves peaceably, and as good subjects of the Commonwealth, shall be equally under the protection of the law"); N.H. CONST. of 1784, supra note 417, pt. I, art. VI (following Massachusetts in these respects); N.J. CONST. of 1776, supra note 417, art. XIX (protecting the civil and office-holding rights of Protestants).

419 See, e.g., supra notes 408-16 and accompanying text (noting that Congregationalism was effectively the established religion of Massachusetts).

See supra notes 90-93 and accompanying text (Locke); Price, OBSERVATIONS, supra note 245, at 240-44.

${ }^{421}$ See supra notes 129-33 (Pufendorf), 220-22 (Hutcheson), 251-53 (Witherspoon) and accompanying text. 
is an inalienable right that belongs to all alike and the notion that the state may establish a religion and thereby inevitably favor some over others. ${ }^{122}$ And there is an even greater conflict between the principle of religious liberty and the idea that individuals may be denied equal civil or political rights because of their religious views.

\section{THE BATTLE OVER RELIGIOUS FREEDOM IN 1780S VIRGINIA}

These conflicts came to a head in the battle over religious freedom and disestablishment that occurred in Virginia during the mid-1780s. This controversy produced one of the era's fullest debates over the meaning of this freedom, and it has long been regarded as providing vital insight into the ideas that underlie the Free Exercise Clause of the First Amendment.

\section{A. The Controversies of the Mid-1780s}

\section{The General Assessment Bill}

Anglicanism was the established religion of Virginia throughout the colonial period. ${ }^{423}$ All inhabitants were required to attend weekly services in their parish churches and to pay taxes for their support. ${ }^{424}$ During the eighteenth century, a limited degree of toleration was afforded to dissenting Protestant sects, provided that they paid these taxes and complied with strict regulations regarding worship. ${ }^{425}$ Members of groups like the Separate Baptists who preached in defiance of these regulations sometimes faced harsh persecution. ${ }^{426}$

In 1776 , this approach to dissent was repudiated by article 16 of state Declaration of Rights, which proclaimed that all individuals were equally entitled to the free exercise of religion. ${ }^{427}$ The debate then turned to the status of the Anglican Church. The dissenting sects and liberal allies such as

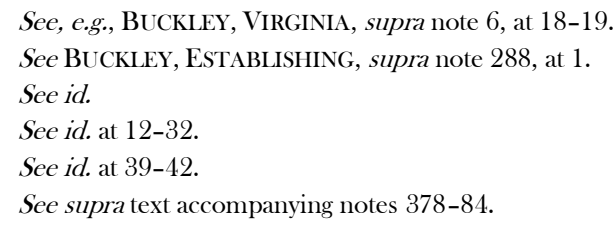


Madison fought to disestablish it. ${ }^{428}$ Although these efforts fell short in 1776, the legislature relieved dissenters of the obligation to pay taxes to support the church. ${ }^{429}$ The legislature also suspended, and eventually abolished, the duty of all citizens to pay such taxes. ${ }^{430}$ Due to lack of revenue and other factors, the church found itself in increasingly dire straits. ${ }^{431}$

In 1784, Patrick Henry spearheaded an effort to pass a bill to combat what he and others regarded as the decline of religion and morality in Virginia. ${ }^{132}$ Rather than declaring Christianity to be "the true Religion," as an earlier bill would have done, ${ }^{133}$ Henry's bill was premised on the notion that the spread of "Christian knowledge" was the best way to promote individual morality and preserve social peace. ${ }^{134}$ This proposal, which became known as the General Assessment Bill, effectively would have made Christianity in general the established religion by imposing a state-wide tax for the support of Christian ministers, teachers, and places of worship. ${ }^{435}$ Each individual would have been permitted to designate the "society of Christians" to which his taxes should go. ${ }^{336}$ In this way, the bill sought to promote Christianity "without counteracting the liberal principle heretofore adopted and intended to be preserved by abolishing all distinctions of preeminence amongst the different societies or communities of Christians." ${ }^{\prime 37}$

In December 1784, Henry's bill came close to passage, only to be blocked when the House of Delegates agreed to Madison's motion for a delay to allow

See BUCKLEY, Virginia, supra note 6, at 19-37.

429. See Curry, supra note 408, at 136.

130 Id.

See BuCKLEY, Virginia, supra note 6, at 43-45 (noting factors such as a decreasing clergy, the absence of a bishop, and the suspension of clerical salaries).

${ }^{432}$ See id. ch. 3; CuRrY, supra note 408, at 140-41.

423 BUCKLEY, VIRGINIA, supra note 6, at 56-57, 185-88 (quoting and reprinting a bill considered by the House of Delegates in 1779).

134 A Bill Establishing a Provision for Teachers of the Christian Religion, Virginia (1784), in THE SaCred Rights of Conscience 252, 252 (Daniel L. Dreisbach \& Mark David Hall eds., 2009) [hereinafter Assessment Bill].

${ }_{435} \quad$ See id. at 252-53.

436 Id. at 253.

437 Id. at 252. 
for consideration by the people. ${ }^{138}$ Extensive public campaigns were then launched to mobilize support or opposition to the bill. ${ }^{499}$

Among the most important petitions against the bill was the Memorial and Remonstrance against Religious Assessments ${ }^{40}$ which was written by Madison at the urging of several other prominent liberals. ${ }^{41}$ This document offered the most comprehensive and intellectually powerful defense of religious liberty in eighteenth-century America.

Madison's leading arguments are grounded in the principles of natural rights and natural religion enshrined in the Declaration of Rights. Quoting article 16, he asserts that it is "a fundamental and undeniable truth, 'that Religion ... can be directed only by reason and conviction, not by force or violence." ${ }^{\prime 2}$ It follows that individuals have a right to exercise religion in the way that their own reason and conscience dictate. Drawing on arguments developed by Locke and other writers we have discussed, Madison offers two reasons for regarding this right as an "unalienable" one. ${ }^{43}$ The first is that "the opinions of men, depending only on the evidence contemplated by their own minds cannot follow the dictates of other men." "'s Second, "what is here a right towards men, is a duty towards the Creator," for "every man [has a duty] to render to the Creator such homage and such only as he believes to be acceptable to him. ${ }^{{ }^{45}}$ For these reasons, Madison concludes that individuals

See BuCKLEY, VIRGINIA, supra note 6, at 108-09.

439 See id. ch. 4.

40 James Madison, Memorial and Remonstrance against Religious Assessments, /ca. 20 June/ 1785, NAT'L ARCHIVES: FoundERS ONLINE, http://founders.archives.gov/documents/Madison/01-08-020163 [https://perma.cc/THW5-WP3B] [hereinafter Madison, Memorial].

${ }^{41}$ See id. For an insightful discussion of Madison's views on religion, see Brady, supra note 15, at 45660 .

42. Madison, Memorial, supra note 440, $\$ 1$.

$43 \quad$ Id.

th $I d$

${ }_{45}$ Id. The first of these arguments finds classic expression in Locke's writings. See supra text accompanying notes 81-86. The second echoes Philip Furneaux's Essay on Toleration. See FurNEAUX, TOleration, supra note 190, at 12 (arguing that just as the ability to exercise religion is "a right" that every individual has "with respect to his fellow men, ... so, with respect to God, it is a duty which he owes to him"). For Furneaux's influence on Madison, see Keтcham, supra note 255 , at 66 . 
do not surrender their right to free exercise when they enter civil society, and that the state has no jurisdiction whatever over religion. ${ }^{46}$

Expanding this critique, Madison contends that the Assessment Bill also violates the principle of natural equality. Quoting from the Declaration, he reasons that

[i]f "all men are by nature equally free and independent," all men are to be considered as entering into Society on equal conditions; as relinquishing no more, and therefore retaining no less, $\ldots$ of their natural rights. Above all are they to be considered as retaining an "equaltitle to the free exercise of Religion according to the dictates of Conscience." ${ }^{\text {"र }}$

Relying once more on the idea that religion can be directed only by reason, he continues: "Whilst we assert for ourselves a freedom to embrace ... the Religion which we believe to be of divine origin, we cannot deny an equal freedom to those whose minds have not yet yielded to the evidence which has convinced us." ${ }^{48}$ The Assessment Bill violates this equality by imposing a tax for the support of Christianity, thereby discriminating against non-Christians as well as against those Christian sects who reject the idea of compulsory support for religion. ${ }^{49}$ Instead of "degrad[ing] from the equal rank of Citizens all those whose opinions in Religion do not bend to those of the Legislative authority," a "just Government" should secure the rights of all "by protecting every Citizen in the enjoyment of his Religion with the same equal hand which protects his person and his property; by neither invading the equal rights of any Sect, nor suffering any Sect to invade those of another. ${ }^{\$ 50}$

Like Locke, Madison argues for a strict separation of church and state and warns of the dangers that arise from their union. Drawing on the Radical Whig view of history, he observes that "[i]n some instances [ecclesiastical

Nicholas Miller suggests that, in his second argument, "Madison shifted his emphasis from the Enlightenment's focus on reason to more of a religious view of man's duty toward God.” MiLLER, supra note 10, at 146. By contrast, I would say that both of Madison's arguments are best understood in terms of natural religion-a view that regards religious duty as founded on reason.

46 See Madison, Memorial, supra note 440, $\$ 1$ (stating that religion "is wholly exempt from [the] cognizance" of "Civil Society").

w7 Id. $\$ 4$ (quoting VA. Declaration OF Rights, arts. 1, 16, supra note 1) (emphasis added by Madison).

48 Id.

49 See id. \$\$ 3-4.

(450 $\quad$ Id. $\$ 8-9$. 
establishments] have been seen to erect a spiritual tyranny on the ruins of the Civil authority; in many instances they have been seen upholding the thrones of political tyranny: in no instance have they been seen the guardians of the liberties of the people." ${ }^{{ }^{51}}$

Madison's defense of religious freedom, like that of article 16, appeals not only to natural religion and natural rights but also to a particular conception of Christianity. ${ }^{452}$ For civil rulers to use religion to promote their own ends is "an unhallowed perversion of the means of salvation." ${ }^{, 53}$ An establishment is not needed to support the Christian religion, which historically has been advanced by divine providence without support from-and indeed in opposition to-civil authorities. ${ }^{454}$ Far from maintaining the purity of Christianity, establishment tends to corrupt it by promoting "superstition, bigotry and persecution." Instead of social peace, governmental intrusions into the religious realm generate sectarian conflict and undermine the "Christian forbearance, love and charity" that the Declaration of Rights calls for. ${ }^{456}$ Finally, those who enjoy "the light of revelation" should desire that it spread to "the whole race of mankind"-a goal that is undermined by laws that discourage non-Christians from immigrating to the state. ${ }^{457}$

The great logical and rhetorical force of Madison's Memorial comes from the ways that it draws on both natural religion and Christianity. His central thesis is that the state is devoid of authority in the religious sphere because individuals have an inalienable right to exercise religion in accord with reason and conscience. But he also maintains that religious freedom and nonestablishment are the best ways to promote the Christian religion. This

${ }_{451} \quad I d$. $\$$. Many of the same themes can be found in Madison's notes for a speech he gave during the Assembly's consideration of the Assessment Bill in December 1784. In that speech, he also argued that establishments are unnecessary because human beings have a natural "propensity ... to Religion.” James Madison, Madison's Notes for Debates on the General Assessment Bill, /Outline B], [23-24 December 1784], NAT'L ARChives: Founders OnLine, https://founders.archives.gov/documents/Madison/01-08-02-0104-0003 [https://perma.cc/ZQ82EG6P].

452 See BuCKLEY, Virginia, supra note 6, at 133-34; Miller, supra note 10, at 148.

${ }_{43}$ Madison, Memorial, supra note 440, $\$ 5$.

s.t $\quad$ Id. $\$ 6$.

4.5 $\quad$ Id. $\$ 7$.

${ }^{456} \quad I d$. $\$ 11$ (quoting VA. Declaration OF Rights, supra note 1, art. 16).

${ }_{457} \quad I d . \$ 12$. 
broad approach allows him to appeal to a wide range of groups, from Deists to liberal Anglicans to many Evangelical Protestants.

Madison's was not the only leading petition that highlighted ideas of natural rights and natural religion. The same was true of a memorial that the Assembly received from the Presbyterians, ${ }^{458}$ one of the largest and most influential dissenting groups in the commonwealth. ${ }^{459}$ Some of the petition's arguments are made in specifically Christian terms, including the assertions that it would be "an invasion of the Divine prerogative" for civil rulers to meddle in spiritual affairs, and that the progress of Christianity should be left to "the all directing providence of God." ${ }^{400}$ But the petition's most fundamental claims are that "[r]eligion is altogether personal" and that individuals have an "unalienable" right to exercise it "agreeably to the convictions of reason and conscience." the religious liberty of all, including those "who may be good citizens, but who have not embraced our common faith." ${ }^{162}$ The measure therefore "is a direct violation of [the sixteenth article of] the Declaration of Rights." ${ }^{463}$ The Presbyterians conclude by urging the legislature to enact Jefferson's Bill for Establishing Religious Freedom. ${ }^{464}$

Thus, two of the major petitions against the Assessment Bill relied on arguments drawn from natural rights and natural religion as well as from the dissenting Protestant tradition. This was also true of a third set of petitions, which denounced the bill as "contrary to the spirit of the Gospel and the Bill

458 Memorial of the Presbytery of Hanover, Virginia (Aug. 13, 1785), in SACRED Rights OF CONSCIENCE, supra note 434, at 304 [hereinafter Presbyterian Memorial (1785)].

459 See BuCKLey, Virginia, supra note 6, at 13; see also Rhys Isaac, "The Rage of Malice of the Old Serpent Devil": The Dissenters and the Making and Remaking of the Virginia Statute for Religious Freedom, in The Virginia Statute for Religious Freedom 139, 149-50 (Merrill D. Peterson \& Robert C. Vaughan eds., 2003) (discussing the Presbyterians' use of natural religion).

460) Presbyterian Memorial (1785), supra note 458, at 305-06.

461 Id. at 304-05.

${ }_{402} \quad$ Id. at 305.

463 $I$.

See id. at 306. 
of Rights." ${ }^{{ }^{65}}$ These petitions, which were signed by thousands of Evangelicals, are discussed in depth below. ${ }^{466}$

\section{Jefferson's Bill for Establishing Religious Freedom}

In response to this surge of political opposition, the Assembly quietly allowed the Assessment Bill to die. ${ }^{467}$ With Madison's leadership, the legislature then adopted an amended version of Jefferson's Bill for Establishing Religious Freedom. ${ }^{468}$ This bill, which was first published in 1779, declared:

that no man shall be compelled to frequent or support any religious worship, place, or ministry whatsoever, nor shall be enforced, restrained, molested, or burthened in his body or goods, nor shall otherwise suffer, on account of his religious opinions or belief; but that all men shall be free to profess, and by argument to maintain, their opinions in matters of religion, and that the same shall in no wise diminish, enlarge, or affect their civil capacities. ${ }^{469}$

In an extensive preamble, the Bill articulated a rationale that was cast largely in terms of natural religion and natural rights. The Bill asserted "that Almighty God hath created the mind free" and made it incapable of external restraint; that he intended for religion to be promoted "by its influence on reason alone"; "that the opinions and belief of men depend not on their own will, but follow involuntarily the evidence proposed to their minds"; that opinions "are not the object of civil government, nor under its jurisdiction"; and that government should not interfere with "principles on supposition of their ill tendency," but only when they "break out into overt acts against peace and good order." "70 The "civil rights" we enjoy as members of society "have no dependance on our religious opinions," and therefore for the law to deny any individual the capacity to hold civil office "unless he profess or renounce

4. Petition Against the Bill [from Westmoreland County, Virginia] (Nov. 2, 1784), in SACRED RighTS OF CONSCIENCE, supra note 434, at 307 [hereinafter Westmoreland Petition].

460 See infra text accompanying notes 514-25.

467 See BuCKLEY, ESTABLISHING, supra note 288, at 79-80.

${ }_{408} \quad$ See id. at $155-63$.

A Bill for Establishing Religious Freedom, 18 June 1779, NAT'L ARCHIVES: FOUNDERS ONLINE, https://founders.archives.gov/documents/Jefferson/01-02-02-0132-0004-0082

[https://perma.cc/54XJ-Q86A] [hereinafter Jefferson Bill] (setting forth the Bill as Jefferson drafted it); see also Virginia Act, supra note 14 (the final version of the Bill).

470 Jefferson Bill, supra note 469. 
this or that religious opinion, is depriving him injuriously of those privileges and advantages to which, in common with his fellow citizens, he has a natural right." ${ }^{{ }^{271}}$ Finally, the preamble affirms "that truth is great and will prevail if left to herself; that she is the proper and sufficient antagonist to error, and has nothing to fear from the conflict unless by human interposition disarmed of her natural weapons, free argument and debate., ${ }^{\prime 72}$ The Bill concludes by declaring "that the rights hereby asserted are of the natural rights of mankind, and that if any act shall be hereafter passed to repeal the present or to narrow its operation, such act will be an infringement of natural right." ${ }^{1 / 3}$

The views expressed in Jefferson's Bill emerged in part from his reflections on Locke, Furneaux, and other writers we have explored. ${ }^{474}$ Like those writers

471 Id. At first glance, this assertion seems problematic: because civil offices do not exist in a state of nature, the right to hold them cannot properly be described as "a natural right." See Philip A. Hamburger, Equality and Diversity: The Eighteenth-Century Debate about Equal Protection and Equal Civil Rights, 1992 Sup. CT. REv. 295, 350-51 (1992). The logic behind Jefferson's assertion becomes somewhat clearer if we consider the passage in Furneaux that evidently inspired it. As Furneaux explains, although one does not have an inherent right to actually hold civil offices, "a capacity of being elected or appointed to them, is the right of every good subject; and being deprived of that capacity is plainly an injury; and every injury done to a man merely for his religion, and not on a civil account," is a form of religious "persecution" which is "contrary to the law of nature." Furneaux, LeTTERS, supra note 169, Letter VI, at 164-65 (emphasis added). It follows that imposing such a disability on dissenters prevents them from "enjoying those privileges and advantages to which, in common with their fellow subjects, they have a natural claim.” Id. at 167 n. *. For other passages in Furneaux's Letters that anticipate the language of Jefferson's preamble, see id. Letter III, at 59 (asserting that "human laws have nothing to do with mere principles, but only with those overt acts arising from them, which are contrary to the peace and good order of society"); id. at 60 (stating that the magistrate exceeds his authority when he punishes individuals "on account of the supposed ill tendency of their principles"); id. Letter VI, at 201 (observing that "though they are criminal who do not resist [the temptation to hypocritically change their religious practice in order to satisfy a legal test for civil office]; yet, neither are they innocent, who lay the snare in their way").

472 Jefferson Bill, supra note 469.

${ }_{43}$ Id. A few years after drafting the Bill, Jefferson presented a similar defense of religious liberty, which also cited Furneaux. Thomas JefFerson, Notes on the State of Virginia, Query XVII (1782), reprinted in ThOMas JefFerson: Writings 123, 284-85 \& n. * (Merrill D. Peterson ed., 1984).

47. See supra note 471 (discussing Furneaux's influence on Jefferson's Bill). For some passages in Locke that are echoed in Jefferson's writings, see LOCKe, TOLERATION, supra note 41, at 14 ("It is only Light and Evidence that can work a change in Mens Opinions. And that Light can in no manner proceed from corporal Sufferings, or any other outward Penalties."); id. at 44 (asserting that the "Speculative Opinions" that individuals hold "have no manner of relation to the Civil Rights of the Subjects"); id. at 44-45 (maintaining that the expression of such opinions "does no injury" to others 
and Madison's Memorial, Jefferson's Bill blended the language of natural rights and natural religion with that of the Christian tradition. For example, the Bill's assertion that it was not only "tyrannical" but "sinful" to "compel a man to furnish contributions of money for the propagation of opinions which he disbelieves and abhors" had powerful appeal to Protestant dissenters and was incorporated into the Baptist petitions against the Assessment Bill. ${ }^{475}$ Christian overtones also could be heard in Jefferson's assertion that all attempts to influence the mind by civil incapacitations or punishments "are a departure from the plan of the holy author of our religion, who being lord both of body and mind, yet chose not to propagate it by coercions on either, as was in his Almighty power to do, but to extend it by its influence on reason alone." ${ }^{\natural 76}$ Jefferson's language here seems designedly ambiguous. Christians naturally would take "the holy author of our religion" to be a reference to Christ, and indeed this phrase was inspired by a passage in Locke's Letter that clearly related to him. ${ }^{477}$ At the same time, the phrase was vague enough that it might refer simply to the "Almighty God" who was mentioned earlier in the preamble. Many years later, Jefferson recalled that the assembly had overwhelmingly rejected a proposal to amend the preamble to specify that "the holy author of our religion" was "Jesus Christ"-a decision that Jefferson regarded as proving that the Act's "protection of opinion was meant to be

and that "the business of Laws is not to provide for the Truth of Opinions, but for the Safety and Security of the Commonwealth, and of every particular mans Goods and Person"); id. at 45 (suggesting that "Truth certainly would do well enough, if she were once left to shift for her Self"); see also infra text accompanying note 477 (describing how Jefferson drew on another passage from Locke's Letter). For further discussion, see Sanford Kessler, Locke's Influence on Jefferson's "Bill for Establishing Religious Freedom," 25 J. Church \& ST. 231 (1983).

${ }_{475}$ Jefferson Bill, supra note 469; see Westmoreland Petition, supra note 465, at 308.

$476 \quad$ Jefferson Bill, supra note 469.

${ }^{477}$ After observing that Christ sought to bring people into the church not by "Instruments of Force" but by "the Gospel of Peace," Locke added, "Tho' if Infidels were to be converted by force, . . . we know very well that it was much more easie for Him to do it, with Armies of Heavenly Legions, than for any Son of the Church ... with all his Dragoons." Locke, Toleration, supra note 41 , at 11 . In the notes Jefferson took while reading this passage, he wrote that "our Saviour chose not to propagate his religion by temporal punmts or civil incapacitation, if he had it was in his almighty power. but he chose to <enforce> extend it by it's influence on reason, thereby shewing to others how [they] should proceed." Thomas Jefferson, Notes on Locke and Shaftesbury, 11 October-9 December 1776, NAT'L ARCHIVES: FOUNDERS ONLINE, http://founders.archives.gov/documents/J efferson/01-01-02-0222-0007 [https://perma.cc/LQ5S-PLBN]. 
universal" and to "comprehend ... the Jew and the Gentile, the Christian and Mahometan, the Hindoo and infidel of every denomination."

Before enacting Jefferson's Bill, the Assembly deleted some of the preamble's most rationalistic language, such as the propositions that "the opinions and belief of men ... follow involuntarily the evidence proposed to their minds" and that religion should progress "by its influence on reason alone." ${ }^{79}$ Yet most of the key language survived, from the declaration that "Almighty God hath created the mind free" to the closing assertion that religious liberty is among "the natural rights of mankind." "\$8 Moreover, the most serious effort to amend the Bill simply would have replaced Jefferson's preamble with the language of article 16 of the Declaration of Rights, with its contention that "Religion ... can be directed only by reason and conviction, not by force or violence." ${ }^{\$ 11}$ Thus, while the Assembly moderated Jefferson's articulation of natural religion, it clearly did not reject that notion, and the core of his position remained intact. As Madison wrote to him shortly afterwards, the changes to the preamble "somewhat defaced the composition," but they "did not affect the substance" of a statute that the two men believed would "in this Country [i.e., Virginia] extinguish[] for ever the ambitious hope of making laws for the human mind."

\section{B. Interpreting the Virginia Controversy}

It is agreed on all sides that the events that culminated in the Virginia Act for Establishing Religious Freedom shed crucial light on the meaning of the First Amendment, which was adopted only a few years later. But there is acute

${ }^{478}$ Thomas Jefferson, Thomas Jefferson: Autobiography, 6 Jan. -29 July 1821, 6 January 1821, NAT’L ARCHIVES: FOUNDERS ONLINE, https://founders.archives.gov/documents/Jefferson/98-01-02-1756 [https://perma.cc/52AW-755F]. While the Assembly's journals contain no record of this amendment, it might have been considered in the Committee of the Whole. See BuckLey, VIRGINIA, supra note 6 , at 158 n.45.

49 Jefferson Bill, supra note 469. For the deleted propositions, see the language marked in italics.

480 $\quad$ See id.

481 Va. Declaration OF Rights, supra note 1, art. 16; see BuCKLey, Virginia, supra note 6, at 158, $162-63$.

${ }_{42}$ Letter from James Madison to Thomas Jefferson (Jan. 22, 1786), NAT'L ARChIVES: Founders ONLINE, $\quad$ https://founders.archives.gov/documents/Madison/01-08-02-0249 [https://perma.cc/FA4U-XWDJ]. 
disagreement over how those events should be understood. Traditionally, courts and historians have focused on the contributions made by Jefferson, who drafted the statute, and by Madison, who shepherded it through the legislature after leading the successful fight to defeat Henry's Assessment Bill. ${ }^{483}$

In recent decades, however, a growing number of scholars have stressed that it was the Evangelicals who provided most of the political momentum that led to the establishment of religious freedom in Virginia. ${ }^{484}$ For example, while Madison's Memorial received about 1,700 signatures-an impressive number for the time-the petitions circulated by Evangelicals garnered many more. ${ }^{485}$ Moreover, it was the Presbyterians' decision to drop their previous support for an assessment and to instead endorse Jefferson's Bill that turned the tide, first in the popular debate and then in the legislature. ${ }^{486}$ It follows that "[t]he key to understanding the nature of the religious settlement in Virginia rests with the dissenters" rather than with the Enlightenment rationalism of Jefferson and Madison. ${ }^{487}$

This revisionist interpretation draws much of its force from the notion that the supporters of religious freedom held two sharply different views-an Evangelical view that was rooted in orthodox Christianity and a rationalist view that was secular or at most Deistic. ${ }^{188}$ During the 1780s, those who espoused these views came together to promote religious liberty, but they did so for

483 See supra text accompanying notes 6-9.

48. See, e.g., BuCKLey, Virginia, supra note 6, at 143, 175-82; Miller, supra note 10, at 109-11; RAGOSTA, supra note 6; McConnell, supra note 6, at 1437-41.

485 See BUCKLeY, VIRGINIA, supra note 6, at 147, 175; McConnell, supra note 6, at 1440.

486 See, e.g., BuCKLeY, Virginia, supra note 6, at 136-39, 143, 147-49; McConnell, supra note 6, at 1440 .

487 BuCKLey, Virginia, supra note 6, at 175; see also, e.g., McConnell, supra note 6, at 1446. Departing from the common understanding, McConnell argues that while Jefferson took an Enlightenment rationalist approach to religious freedom, Madison took a very different approach which "echoed evangelical convictions" and exalted "the claims of religious freedom" over those of civil society. See id. at 1446, 1452-55. As I shall show, however, whatever their private views may have been, Madison and Jefferson took the same public stance toward religion-an approach that was rooted in the ideas of natural religion and natural rights. See supra text accompanying notes 440-57, 468-78; infra text accompanying notes 494-96.

See, e.g., BuCKLEy, VIRGINIA, supra note 6, at ix-x, 3, 6, 148, 164, 178-81; McConnell, supra note 6 , at $1437-41,1445-46,1449-53$. 
fundamentally different reasons. ${ }^{489}$ Evangelicals were motivated by "avowedly religious reasons": they held that "[e]very man had to be free to respond in faith and worship as God would draw him," and that the church had to be free to promote "the salvation of a Christian America through the Gospel message." ${ }^{90}$ By contrast, rationalists were indifferent if not hostile toward Christianity and other forms of organized religion. ${ }^{491}$ They wished to protect intellectual freedom and to liberate social and political life from the domination of religion by confining it to the private sphere. ${ }^{492}$ Although the two groups joined forces against the religious establishment during this period, in the end their views were not merely distinct but "diametrically opposed" to one another. ${ }^{193}$ When the two positions are framed in this way, one can make a reasonable case that the defeat of the Assessment Bill and the adoption of the Act for Religious Freedom are best understood in terms of the conception of religious liberty that was held by the Evangelicals, whose political support was decisive, rather than in terms of the Deism, skepticism, or irreligion that they abhorred.

The fundamental problem with this revisionist interpretation is that it fails to take sufficient account of natural religion and to recognize the way that it offered common ground between the rationalist and Evangelical positions. In his private correspondence, Jefferson did articulate Deist views as well as strong hostility toward traditional Christianity. ${ }^{194}$ Although Madison's youthful letters breathed with Evangelical fervor, ${ }^{495}$ in later years he "was extremely

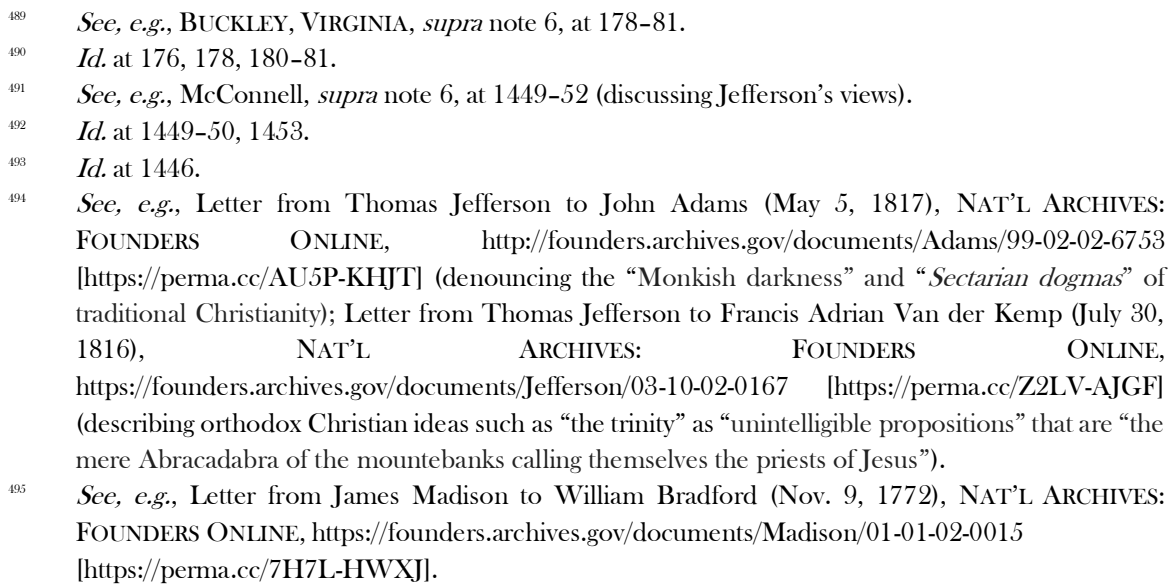


reticent about expressing his ideas on matters of faith." ${ }^{966}$ Yet whatever the two leaders' personal views may have been, the position they took in their public writings was based not on an agnostic or antireligious secularism but on an affirmation of natural religion. Moreover, the form of natural religion they affirmed was one that was open to the possibility of revelation and that recognized the right of all individuals to hold and advocate for their beliefs, including traditional Christian ones. The leading Evangelical defenses of religious liberty in Virginia also rested in part on the concepts of natural religion and natural rights. It was these concepts that enabled rationalists and Evangelicals to form an alliance to promote religious liberty. It follows (as I shall now argue) that the statute and its adoption are best understood neither in terms of secular rationalism nor in terms of Evangelicalism but rather in light of natural religion and natural rights.

At the outset, we should clarify the question we are interested in. Some forms of history would focus on the social and political forces that brought about the statute's adoption or would explore its implications for religion, politics, and society in Virginia. Although these are relevant to our inquiry, they are not our principal concern. Instead, the question is how we should understand the normative principle of religious liberty as it was incorporated into the fundamental law of the state by the Act for Religious Freedom. What did that statute mean from a legal and constitutional standpoint?

In pursuing this issue, we should begin with the statute's language. Although its rationalism was toned down as it made its way through the legislature, it clearly is based on ideas of natural religion and natural rights. The Act declares that God has created the mind free; that human beings are capable of reaching "truth" through "free argument and debate"; that they have an inherent right to formulate and argue for their beliefs, as well as to be free from all compulsion in this sphere; that they are entitled to full and equal "civil rights" without regard to their religious opinions; that those opinions lie beyond the legitimate authority of civil government; and that the rights asserted are among the inviolable "natural rights of mankind." ${ }^{{ }^{97}}$

${ }^{496}$ Ralph L. Ketcham, James Madison and Religion-A New Hypothesis, 38 J. Presbyterian Hist. SOC’Y 65, 65 (1960).

${ }^{497} \quad$ Virginia Act, supra note 14. 
At the same time, Jefferson's statute does not articulate these ideas in a way that is antagonistic to revealed religion, for the Act speaks respectfully of "the Holy author of our religion," "the ministry," and the "faith" of individuals. The statute seems to assume that individuals reasonably can hold a variety of religious views. It also incorporates a number of points that would appeal to dissenting Protestants, such as a denunciation of rulers who would impose their (quite possibly false) opinions on others. ${ }^{199}$ Yet it studiously refrains from using explicitly Christian language. In short, like Madison's Memorial, the Act is a classic instance of a document that is founded on natural religion but open to revealed religion, that appeals to both rationalist and pietist defenders of religious freedom, and that secures this freedom to everyone under the doctrine of natural rights.

This leads to the next point: the Act's supporters and their views. Although a wave of Evangelical activity may have ensured the defeat of the Assessment Bill, that activity was not sufficient to secure the adoption of a law protecting religious liberty. Instead, that result was achieved by a broader political and legislative coalition that also included Anglicans (or Episcopalians, as they became known after the Revolution). ${ }^{500}$

As we have seen, eighteenth-century Anglican thought had both a traditionalist and a rationalist strand. ${ }^{501}$ The latter emphasized the importance of reason as well as the harmony between natural and revealed religion. ${ }^{502}$ Some rationalists agreed with traditionalists on the value of an established church. ${ }^{503} \quad$ But others strongly supported religious liberty and disestablishment. ${ }^{504}$ During the mid-1780s, individuals who took this liberal Episcopalian position held about nineteen seats in the House of Delegates. ${ }^{505}$

$198 \quad I d$.

Id.

500 See, e.g., Buckiey, Establishing, supra note 288, at 80.

501 See supra text accompanying notes 286-87.

${ }_{302} \quad$ See supra text accompanying notes 288-90.

${ }_{503}$ For example, James Maury's discourse was written to defend the established church against the challenge posed by Separate Baptists. See MAURY, supranote 288; BUCKLEY, ESTABLISHING, supra note 288 , at 43.

Sol See, e.g., BUCKLLY, VIRGINIA, supra note 6, at 124-25, 128, 130-31, 164.

${ }_{505} \quad$ See id. app. II, at 192-200 (listing a group of delegates who favored a church-state relationship as well as a group that opposed one-a category that he subdivides between Episcopalian rationalists and predominantly Presbyterian dissenters). 
Together with a similar number of Evangelicals, they had the strength to block the Assessment Bill and to enact Jefferson's statute. ${ }^{506}$ A few months later, such efforts to secure religious liberty and to dissolve the union between church and state were hailed as a triumph for rational religion and "the rights of humanity" in a sermon preached to the Episcopal Church of Virginia by the Rev. James Madison, who was soon to become its first bishop. ${ }^{507}$

The other main part of the coalition for religious liberty consisted of Evangelical dissenters from the established church. This was not a unified group, however, for it consisted of several distinct denominations, the largest of which were the Presbyterians and Baptists. At this time, nearly all the Evangelical members of the House of Delegates were Presbyterians. ${ }^{508}$

Presbyterians had long resented the dominance of the Anglican Church in Virginia. ${ }^{509}$ They were committed to religious liberty and equality for all Christian sects. ${ }^{510}$ During the fall of 1784, they expressed qualified support for an assessment because of religion's importance for "the existence and welfare" of society. ${ }^{511}$ The following summer, however, they changed course and denounced Henry's proposal as an invasion of the religious sphere and "a direct violation of the Declaration of Rights. ${ }^{\prime 12}$ As we have seen, their memorial to the General Assembly contained strong elements of natural

506 See id.; Buckiey, Establishing, supra note 288, at 80; supra Part IV.A.

507 See James Madison, a Sermon Preached Before the Convention of the Protestant EPISCOPAl Church In the STATE OF Virginia, ON THE TwENTY SiXTH OF MAY, 1786, at 3-7 (Richmond, Thomas Nicolson 1786). In a statement that epitomizes natural religion, Madison asserted that "religion, to be profitable to the individual and acceptable to God, must be the result of free inquiry and the determination of reason. This right of free inquiry, and of judging for ourselves is a right natural and unalienable." Id. at 10. For Madison, this right was not only "the glory of our nature" and "the truest source of joy and triumph to an American," it was also "the indispensable duty of a Christian." Id.

${ }_{508}$ See BUCKLEY, VIRGINIA, supra note 6, app. II, at 199-200.

Sol $\quad$ See id. at 137-39.

${ }_{510}$ See Memorial of the Presbytery of Hanover, Virginia (Oct. 24, 1776), in SACREd Rights of CONSCIENCE, supra note 434, at 269, 269-70, https:/teachingamericanhistory.org/library/documen t/the-memorial-of-hanover-presbytery/ [https:/perma.cc/J645-83Z6] [hereinafter Presbyterian Memorial (1776)].

sil Memorial of the Presbytery of Hanover, Virginia (Oct. 28, 1784), in SACred Rights of CONSCIENCE, supra note 434, at 301, 303.

512 See Presbyterian Memorial (1785), supra note 458, at 304-05. 
religion and urged the adoption of Jefferson's Bill. ${ }^{513}$ It therefore is fair to say that ideas of natural religion and natural rights were affirmed by both of the groups-Presbyterians and liberal Episcopalians-that formed the legislative coalition that passed the Act for Religious Freedom.

Much of the revisionist case instead focuses on the Baptists. The most widely subscribed petitions against the Assessment Bill probably were their work. ${ }^{514}$ These petitions objected to the bill primarily in Christian terms. By imposing a tax for religious purposes, the legislature would act "contrary to the spirit of the Gospel” by disregarding Christ's "plain directions" that the church and its teachers should be supported "by free Contributions." bill's supporters are correct "that Deism with it's banefull Influence is spreading itself over the state," the proper remedy is not to establish religion. ${ }^{516}$ Instead, the rulers should promote religion by setting a good example as well as by adopting laws to punish immorality. ${ }^{517}$ Ministers should demonstrate to the world that they are called to their work by "divine Grace" and not by a mere desire to profit from ecclesial employment. ${ }^{518}$ But on no account should civil government meddle in the religious realm. ${ }^{519}$

Several scholars rely on these petitions as important evidence that the adoption of the Virginia statute should be regarded as a victory for an Evangelical rather than an Enlightenment view of religious liberty. ${ }^{520}$ But this evidence does not bear the weight that is placed on it.

To begin with, we should recall that the specific purpose of these petitions was to oppose the Assessment Bill. In turn, the rationale for that bill was that it offered the best way to diffuse "Christian knowledge" throughout the community and to thereby promote social peace and morality. ${ }^{521}$ In this context, it is perfectly understandable that the petitions should contend that, far from promoting true Christianity, the Assessment Bill violated the most




basic principles of that religion as the Baptists understood it. Thus, the bill could be accused of failing on its own terms by undermining the very goal it sought to promote. The petitions made no effort to articulate a general rationale for protecting religious liberty in the new republic. There is no reason to suppose that, if they had, they would have offered a justification that focused purely on the idea of Christian liberty to the exclusion of other rationales.

On the contrary, the petitioners took pains to argue not only that the Assessment Bill contravened "the spirit of the Gospel," but also that it infringed the natural freedom and equality of non-Christians by granting Christians exclusive benefits in violation of "the Bill of Rights." ${ }^{522}$ In this way the petitioners signaled that they accepted the doctrine of natural rights and recognized that those rights belonged to everyone regardless of religion.

Although the natural rights argument did not hold center stage in these petitions, it nevertheless was integral to the position they took. That position was based on a sharp distinction between church and state. The petitions' first argument was that the Assessment Bill violated the doctrines of the Christian church as set forth in the Gospel, while the second argument was that the Bill violated the principles of the Commonwealth of Virginia as set forth in the Declaration of Rights. The first argument expressed the Baptists' own religious beliefs, while the second appealed to precepts that had been declared by the representatives of all the people of Virginia. In this way, the two arguments were perfectly complementary, and from a Baptist perspective each would have been lacking without the other.

It is hardly surprising that the petitioners did not undertake to develop a general defense of religious liberty, for they were well aware that a powerful one already existed in the form of Jefferson's Bill. The Baptists had endorsed that bill when it was first published in 1779, and they were among its principal supporters. ${ }^{523}$ Some of its key language was incorporated into the Baptist petitions of 1785, including the assertion that religious matters "are not the object of Civil Government, nor under it's jurisdiction.” ${ }^{24}$ The Baptists

Id. at 307-08.

${ }_{523}$ See BuCKLey, Virginia, supra note 6, at 55; BUCKLey, ESTABLISHING, supra note 288, at 71-72.

S24 See Westmoreland Petition, supra note 465, at 308. 
welcomed the statute's passage in 1786, and in later years they strongly identified with it. ${ }^{525}$

Some scholars contend that the Baptists supported Jefferson's statute not for what it said but for what it did: the law "served their purposes" by disestablishing Anglicanism, protecting religious liberty, and enabling them to promote "the salvation of a Christian America through the Gospel message." ${ }^{226}$ But some prominent Baptists advocated for religious liberty in ways that strongly echoed Locke and Jefferson. For example, Elder John Leland presented such a justification in a sermon entitled The Rights of Conscience Inalienable. ${ }^{527}$ Leland's views are of particular interest because he not only played an important role in Baptist political activity at this time, but also was instrumental in securing Madison's commitment to promote a federal constitutional amendment to protect religious liberty. ${ }^{528}$

According to Leland, the American states have recognized that civil government should be based on "compact." ${ }^{529}$ Individuals enter civil society to protect themselves and their property from violence. ${ }^{330}$ The "rights of conscience" are "inalienable," for "religion is a matter between God and individuals," and one's "mind should always be open to conviction" and willing to "receive that doctrine which appears the best demonstrated." ${ }^{331}$ Truth

${ }_{525}$ See Isaac, supra note 459, at 158-59. An early official history of the Virginia Baptists lauded not only Jefferson's Bill but also Madison's Memorial, observing that "[f]or elegance of style, strength of reasoning, and purity of principle, [the latter] has ... never [been] surpassed by any thing in the English language.” Robert B. Semple, The History of the Rise and Progress of the BAPTISTS IN VirginIA 33, 72 (John O'Lynch 1810), [https://perma.cc/6XBF-VTST]. Passages like this suggest that contemporaries saw less difference between the Evangelical and Enlightenment positions on religious liberty than modern scholars do. Cf. BUCKLEY, VIRGINIA, supra note 6, at 148 (asserting that there was a "wide gap" between those two positions but acknowledging that this gap may have been "unrecognized at the time").

${ }^{526}$ BuCKLeY, Virginia, supra note 6, at 180-81. Buckley offers this assertion not only about the Baptists but also about the Evangelicals in general. This view fails to capture the position of the Presbyterians, who highlighted ideas of natural religion and natural rights in their memorial against the Assessment Bill. See supra text accompanying notes 458-64.

${ }^{327}$ John Leland, The Rights of Conscience Inalienable (1791), reprinted in 2 Political SERMONS, supra note 105, at 1079, 1080 [hereinafter LELAND, CONSCIENCE].

Seg See RagOSTA, supra note 6, at 167-68.

529 LELAND, CONSCIENCE, supra note 527, at 1083.

Id. at 1084 .

531 Id. at 1084-85. In a similar vein, a Baptist petition against the Assessment Bill observed that "Christianity addresses itself to the understanding and affections of Men, and [seeks] to attach them 
comes from studying "nature and reason" as well as "the bible," and is best pursued through free and open discussion. ${ }^{332}$ It follows that everyone should be allowed to "maintain the principles that he believes [and to] worship according to his own faith, either one God, three Gods, no God, or twenty Gods." ${ }^{\text {533 }}$ Human lawmakers may not compel anyone to pay taxes for religious purposes, and compulsion of this sort would be unjust to Deists, Jews, Catholics, Muslims, and others who reject Christianity. ${ }^{534}$

Leland's views present a paradox. For six decades, he travelled the countryside preaching a traditional Calvinist message "that human powers were too degenerate to effect a change of heart by self-exertion" and that individuals could be saved only through faith in the atoning power of Christ's death on the cross. ${ }^{535}$ Yet when Leland sought to persuade the public to protect religious liberty, he emphasized reason and natural rights. How can these two positions be reconciled?

In part, the answer seems to be that Baptists like Leland did not see as much tension between the two positions as we might today. God was both the creator and the redeemer of the world. While Leland might believe that

to its Interests only by Arguments adapted to convince them of its native excellence, and its importance to their happiness. If these considerations fail it has no others to propose." Remonstrance and Petition of Committee of General Baptist Association at 2 (Aug. 13, 1785, received by General Assembly Nov. 3, 1785), http://www.virginiamemory.com/collections/petitions [https://perma.cc/QE4S-UF9L] [hereinafter General Baptist Petition].

532 LELAND, CONSCIENCE, supra note 527, at 1089-90.

539 Id. at 1089. This statement recalls Jefferson's famous assertion that religion is beyond the state's authority because "it does me no injury for my neighbour to say there are twenty gods, or no god. It neither picks my pocket nor breaks my leg.” JEFFERSON, supra note 473, QUERY XVII, at 285.

534 Leland, CONSCIENCE, supra note 527, at 1092-93. In other writings, Leland articulated these themes in equally powerful terms. See, e.g., John Leland, The Virginia Chronicle, in The Writings OF THE LATE ELDER JoHn LELAND 91, 105-09, 117-19, 121-23 (L.F. Greene ed., New York, G.W. Wood 1845), https://ia802605.us.archive.org/11/items/writingsoflateel00lela/writingsofl ateel00lela.pdf [https://perma.cc/RD6N-U6YJ] [hereinafter LELAND'S WRITINGS]; JOHN LELAND, The Yankee Spy (1794), in Leland's Writings, supra, at 213, 219-29; John Leland, Short Sayings, in LELAND's Writings, supra, at 572, 573, 578-81. Leland was not alone in taking such an approach. For instance, the first election sermon delivered by a Baptist clergyman to the Massachusetts legislature also defended civil and religious liberty in Lockean terms. See SAMuel Stillman, a Sermon Preached Before the Honorable Council ... at 7-9, 11-14, 22 (Boston, T. \& J. Fleet 1779) [https://perma.cc/D9ZT-N4YP].

${ }^{335}$ JOHN LELAND, Events in the Life of John Leland, in LELAND's WriTINGS, supra note 534, at 2, 28, 39. 
salvation came only through faith, that did not negate the idea that God was also the author of the natural order and of the rights that human beings had within it. One could believe in "nature's God" as well as in the God of the Bible; there was no necessary conflict between understanding life in this world in terms of natural rights and believing that revelation offers the only path to attaining life in the world to come. ${ }^{536}$ To put it another way, however God may have determined to bring about salvation, individuals have an inalienable right to liberty of conscience in relation to other human beings. ${ }^{337}$

Leland's writings also suggest another (not incompatible) way to resolve the paradox. He is well aware that different forms of discourse are called for in different spheres of life. For example, although it was reasonable for the statesmen who drafted the Massachusetts Declaration of Rights to declare "that all men came into the world free and independent," it is equally reasonable for parents to regard young children as dependent and in need of control. $^{538}$ By the same token, it may be appropriate to describe religious liberty as one of the inherent rights of humans as rational creatures when advocating for its protection in the constitution of a liberal polity, while asserting that all humans are naturally sinful when speaking from an Evangelical theological perspective. ${ }^{539}$ These different forms of discourse are suited to the contexts in which they are used and to the audiences to whom they are addressed. On this view, there is no necessary contradiction between preaching Baptist doctrines regarding salvation, as Leland did throughout his ministry, and defending liberty of conscience as a natural right, as he did in advocating constitutional and legal reform. ${ }^{5+0}$

536 JOHn LeLAND, A Blow at the Root (1801), in LeLAND's WritingS, supra note 534, at 233, 255; see also John Leland, Circular Letter of the Shaftsbury Association (1793), in Leland's Writings, supra note 534, at 196, 196-99 (presenting reasons for holding that the Bible is the word of God); JOHn LeLAND, An Elective Judiciary (1805), in LELAND's Writings, supra note 534, at 283, 294 (stating that the Christian religion involves mysteries that are "not of this world" and that cannot be understood through natural reason).

537 See, e.g., LELAND, A Blow at the Root, supra note 536, at 239 (discussing the inalienable right to freedom of conscience).

s38 Id. at 235-36 (paraphrasing MAss. CONST. of 1780, supra note 403, pt. 1, art. I).

See id. at 237, 239.

510 See supra text accompanying notes 529-34; John LeLAnd, Speech Delivered in the House of Representatives of Massachusetts, on the Subject of Religious Freedom (1811), in LELAND's WRITINGS, supra note 534, at 353. 
This distinction between different forms of discourse may also shed some light on the views of the Rev. Isaac Backus, the Massachusetts pastor and scholar who was perhaps the most influential Baptist leader in late eighteenthcentury America. ${ }^{511}$ Although his writings on religious liberty endorsed Locke's position on the separation of church and state, they generally relied not on natural rights theory but on Scripture and Baptist theology. ${ }^{542}$ Yet in 1779 when a friend asked him to draft a bill of rights in advance of the Massachusetts constitutional convention, the document he produced emphasized the "natural, inherent, and unalienable rights of mankind." ${ }^{513}$ The article on religion read as follows:

As God is the only worthy object of all religious worship, and nothing can be true religion but a voluntary obedience unto his revealed will, of which each rational soul has an equal right to judge for itself, every person has an unalienable right to act in all religious affairs according to the full persuasion of his own mind, where others are not injured thereby. ${ }^{5.4}$

The language of rational religion in this passage is unmistakable. To be sure, the reference to God's "revealed will" might suggest that "true religion" is based on revelation. ${ }^{5+5}$ During this era, however, it often was said that God revealed his will through nature and reason as well as through Scripture. ${ }^{546}$ In any event, the passage makes clear that "each rational soul" has a right to use "his own mind" to determine religious truth. ${ }^{517}$ Thus, while some of Backus's writings argue for religious freedom as a matter of "Christian liberty" under

s4 On Backus, see MCLoughuin, supra note 416; Miller, supra note 10, at 101-13, 387.

52 See Isaac Backus, A Seasonable Plea for liberty of Conscience 4-5 (Boston, Philip Freeman 1770), http://name.umdl.umich.edu/N09053.0001.001 [https://perma.cc/RLF9-8RYH]; IsaAC Backus, An Appeal to the Public for Religious Liberty (1773), in Backus PAMPHLETS, supra note 413, at 303; id. at 40-44 (editor's introduction).

st3 Isaac Backus' Draft for a Bill of Rights for the Massachusetts Constitution, art. I (1779), in BACKUS PAMPHLETS, supra note 413, at 487 [hereinafter Backus, Draft].

su Id. art. II, at 487.

545 Id.; see MCLOUGHLIN, supra note 416, at 144 .

st6 See, e.g., Gerrish, supra note 15, at 646-47 (distinguishing between "general revelation" through nature and "special revelation" through Scripture). For example, Locke maintained that "Reason is natural Revelation, whereby [GOD] communicates to Mankind that portion of Truth, which he has laid within the reach of their natural Faculties," while "Revelation is natural Reason enlarged by a new set of Discoveries communicated by GOD immediately.” LOCKe, HuMAN UNDERSTANDING, supra note 19, bk. IV, ch. XIX, $\$ 4$, at 698 .

s47 Backus, Draft, supra note 543, art. II, at 487. 
the Gospel, ${ }^{518}$ his draft bill of rights portrays it as "an unalienable right" of all human beings that has no inherent connection with Christianity. ${ }^{59}$ To put the point somewhat differently, Backus's draft resembles both the Virginia Declaration and Jefferson's Bill in using some language that resonates with Christianity, ${ }^{550}$ but in ultimately affirming that rational creatures have a natural right to follow the judgments of their own minds about religious truth.

\section{Conclusion}

The revisionist scholarship of recent decades has greatly enriched our understanding of the theological ideas and political forces that contributed to the victory of religious liberty and disestablishment in Virginia. As I have explained in this Part, however, it would be a mistake to conceive of the normative constitutional meaning of that victory in terms of the Evangelicals' distinctive theological position. Instead, that meaning is best understood in terms of the principles that provided the basis of their coalition with rationalist Christians and Enlightenment liberals and that were articulated in Jefferson's Bill-that because God created the mind free, individuals have an inalienable natural right to form and advocate their own opinions regarding religious truth and that the state has no legitimate power in this realm. ${ }^{5.52}$

The revisionist position also takes another form. In an important book entitled The Religious Roots of the First Amendment, Nicholas P. Miller argues that the founding-era conception of religious freedom derived from a

st ISAAC BACKUS, A DOOR OPENED FOR Christian LiberTy (1783), in BACKus PAMPHLETS, supta note 413 , at $427,436$.

sig $\quad$ Backus, Draft, supra note 543, art. II, at 487.

${ }_{350}$ In addition to the references to God's "revealed will" and the "soul," this language includes "the full persuasion of his own mind." This phrase, which also appears in the English version of Locke's Letter Concerning Toleration, ultimately derives from St. Paul's Letter to the Romans. See LockE, Toleration, supra note 41, at 13 ("All the Life and Power of true Religion consists in the inward and full perswasion of the mind ...."); Romans 14:5 ("Let every man be fully persuaded in his own mind.”). All biblical quotations herein are to the King James Version, which was in general use at the time.

See supra text accompanying notes 378-83 (Virginia Declaration), 468-82 (Jefferson’s Bill). In 1789, Backus praised Virginia for adopting Jefferson's statute. See BUCKLEY, Establishing, supra note 288 , at $40-43$.

See Virginia Act, supra note 14. 
particular strand of Protestant thought. ${ }^{5.53}$ At the heart of the Reformation was the idea of sola scriptura-the assertion that religious truth was to be found not in traditional church teachings but in Holy Scripture alone. ${ }^{5.54}$ The question then became how-and by whom-Scripture was to be interpreted. The jurisdictions that broke from Rome generally established churches that asserted their own authority to interpret the Bible and to impose religious doctrines with the backing of the state. ${ }^{5.55}$ Dissenting from this position, other Protestant sects such as Baptists and Quakers insisted that every believer possessed a "right of private judgment," that is, a right to interpret Scripture for himself with the assistance of the Holy Spirit.

Miller contends that this notion of a right of private judgment was the starting point for the modern conception of religious liberty. Initially, that right related only to biblical interpretation. ${ }^{537}$ Over time, however, dissenting Protestants came to conceive of the right as extending to religious truth in general. ${ }^{5.58}$ In the late seventeenth century, the principle of private judgment was given philosophical form by Locke. ${ }^{559}$ Eighteenth-century Americans then drew on Lockean as well as dissenting Protestant thought when they asserted that individuals had an inherent right to religious liberty that was entitled to legal and constitutional protection. ${ }^{500}$

Miller persuasively shows that this Protestant view made an essential contribution to the American conception of religious liberty. At times, he

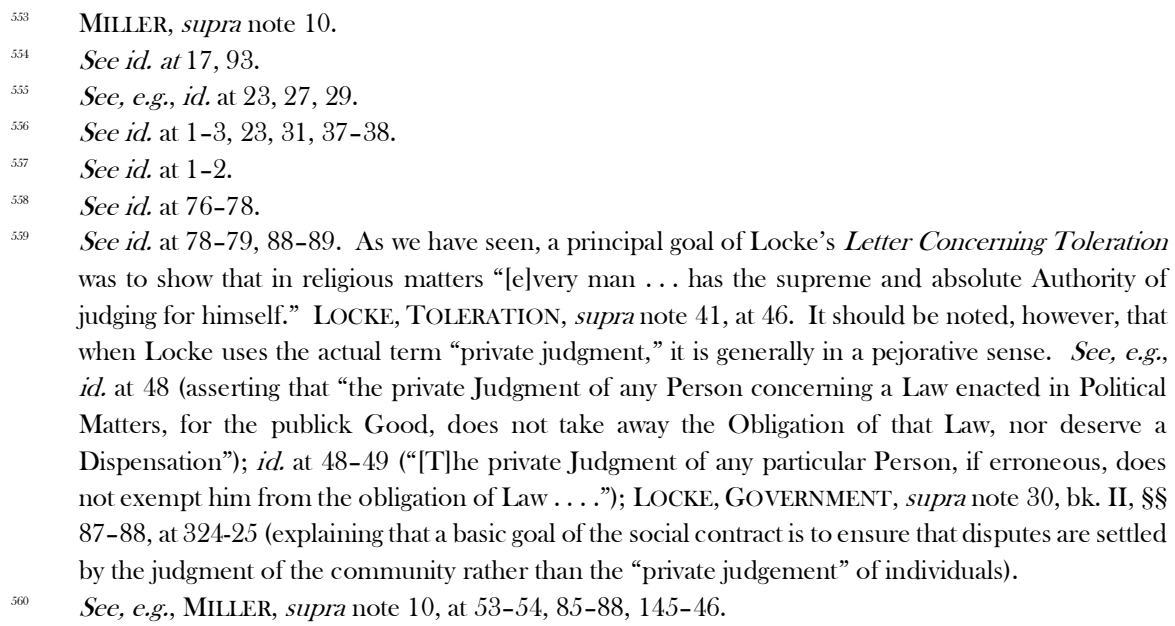


describes dissenting Protestantism as a movement that "worked alongside" and "converged" with "other ideologies" such as Enlightenment liberalism. ${ }^{561}$ Yet Miller often seems to make a more far-reaching claim: that the foundingera conception should be understood primarily in terms of dissenting Protestant thought. ${ }^{562}$ On this view, Locke's writings on toleration merely gave "philosophical and political expression [to] what were perceived to be Protestant theological principles," but did not add anything essential to them. ${ }^{563}$ "It was Locke's formulation ... of dissenting Protestantism," Miller concludes, "mediated by Madison, Witherspoon, and other key American thinkers, ... that carried the day in the founding of the American republic. ${ }^{964}$

In my view, this broader form of Miller's position is unconvincing for two reasons. First, we should not focus on dissenting Protestantism at the expense of other influences. Although the right of private judgment was a distinctively Protestant idea in origin, the same cannot be said of reason and nature-ideas that were no less central to the eighteenth-century American understanding of religious liberty. Among the sources of those ideas were modern natural science $^{565}$ and the tradition of natural law and natural right theory which stretched back through early modern and medieval Scholasticism to classical Roman and Greek philosophy. ${ }^{566}$

Id. at $1,4,7$.

${ }_{502}$ See, e.g., id. at 3 (asserting that the right of private judgment "grew from theological rather than secular Enlightenment roots"); id. at 4 ("Disestablishment in America was a populist movement where religious, and not Enlightenment, influences predominated.”); id. at 13 (maintaining that dissenting Protestants "played [a] greater role [than Madison] in bringing the principle of religious liberty and disestablishment to the early American republic").

s63 Id. at 77-82, 90; see also id. at 80-82, 89 (suggesting that Locke can best be understood as a dissenting Protestant theorist).

36t Id. at 162; see also id. at 145 (referring to "the core theological and biblical issues that lay at the heart of Madison's belief in the right of personal liberty"). For another sophisticated version of this argument, see SMITH, supra note 9, at 39-40 (arguing that "insofar as it fed into American religious freedom," the Enlightenment is best understood as “a conduit" for Christian ideas).

s66s See supra Part II.E.

s66 See, e.g., HAAKONSSEN, supra note 192, ch. 1; SCHNEEWIND, supra note 228, at 17; LeO STRAuss, Natural Right and History (1953). Miller shows that even before Locke, dissenting Protestant writers made appeals to reason and nature. See MiLler, supra note 10, at 69, 77-78, 81-82. But he does not explore the origin of those ideas or recognize the ways in which they are in tension with core principles of Protestantism like sola scriptura and the corruption of human nature by the Fall, see supra text accompanying notes 295-97, 554 . 
Second, we should recognize that, over the course of time, the idea of a right of private judgment evolved in ways that carried it far beyond its Reformation roots. As Miller observes, it developed from a right to interpret Scripture for oneself into a right to seek religious truth in general. ${ }^{567}$ The progression did not stop there, however. By the eighteenth century, the right to private judgment was being described in even broader terms. As Hutcheson put it, it consisted in the "natural right" of "every intelligent being" to form all of "his own opinions, speculative or practical, ... according to the evidence that appears to him"-a right that arises "from the very constitution of the rational mind. ${ }^{968}$

In short, between the Protestant Reformation and the American founding, the idea of private judgment underwent a fundamental transformation, by which it came to encompass not only a right of religious believers to interpret the sacred texts of their own tradition with the assistance of divine illumination, but also a right of all human beings to use their reason to search for religious, philosophical, moral, and other forms of truth. ${ }^{569}$ It was this reformulation of the idea in the universal language of natural religion and natural rights that enabled it to be integrated into the intellectual worldview of the eighteenth century, to be used as the basis of a broad political coalition for the protection of religious liberty, and to be incorporated into American legal and constitutional documents that declared the natural rights of mankind.

567 See MiLler, supra note 10, at 76-78.

568 1 HutCheSON, System, supra note 194, bk. II, ch. 5 , $\$ 3$, at 295 . For an earlier statement to this effect, see Francis Hutcheson, AN INQUiRy inTO the Original OF OUR IDEAS OF BEaUTY AND VIRTUE bk. II, § VII, at 186 (Wolfgang Leidhold ed., rev. ed., Liberty Fund 2008) (2d ed. 1726), https://oll.libertyfund.org/titles/hutcheson-an-inquiry-into-the-original-of-our-ideas-of-beautyand-virtue-1726-2004 [https://perma.cc/H564-34DY].

${ }^{369}$ Like Hutcheson, Witherspoon taught that individuals have an inalienable "right of private judgment in matters of opinion," thought, and knowledge, as well as "in all matters of religion." WiTHERSPOON, supra note 246, at 56,69. In his American edition of Blackstone, the Jeffersonian jurist and Deist St. George Tucker articulated this more comprehensive view when he wrote that individuals have an inalienable "right of personal opinion" that embraces both (1) "liberty of conscience in all matters relative to religion" and (2) "liberty of speech and of discussion in all speculative matters, whether religious, philosophical, or political." 1 WiLLIAM BLACKSTONE, Commentaries on the Laws OF England app. Note G, at 3-4, 6-7, 11 (St. George Tucker ed., Philadelphia, Young \& Small 1803), https://lonang.com/library/reference/tucker-blackstone-notesreference/tuck-2g/ [https://perma.cc/5W6B-HWSA]. 


\section{THE Adoption OF THE FEDERAL CONSTITUTION AND BILl OF RIGHTS}

\section{A. The Debate over the Constitution}

\section{The Demand for a Bill of Rights}

When the Federal Convention met during the summer of 1787 to draft a new constitution, the delegates focused on strengthening the powers of the national government and on reaching compromises between competing state and regional interests. Securing constitutional protection for individual rights was at most a peripheral concern. Toward the convention's end, George Mason of Virginia and Elbridge Gerry of Massachusetts moved that a committee be appointed to draft a bill of rights, but their proposal was rejected with little debate..$^{570}$

This decision was "a critical error that almost proved fatal," for the lack of a bill of rights turned out to be the most effective line of attack against the Constitution when it was submitted to the people for ratification. ${ }^{571}$ In state after state, Antifederalists excoriated the document for failing to secure "the great, important rights of humanity" which were "essential to liberty and happiness. ${ }^{972}$ Together with trial by jury and freedom of speech and press, these rights included "LIBERTY OF CONSCIENCE." ${ }^{373}$ As one writer put it, invoking the natural rights/natural religion language of the Pennsylvania Declaration of Rights, "all men have a natural and unalienable right to worship

370 See James Madison, The Debates on the Adoption of the Federal Constitution in the Convention Held at Philadelphia in 1787, at 538 (Jonathan Elliot ed., 1827), https://oll.libertyfund.org/titles/madison-the-debates-on-the-adoption-of-the-federal-constitution-vol5 [https://perma.cc/PV6D-QH96] [hereinafter MADISON, DEBATES].

${ }^{571}$ Creating the Bill of Rights: The Documentary Record from the First Federal CONGRESS ix (Helen E. Veit, Kenneth R. Bowling \& Charlene Bangs Bickford eds., 1991).

372 3 Jonathan Elliot, The Debates in the Several State Conventions on the Adoption OF THe Federal Constitution 317, 593 (2d ed. 1827) (remarks of Patrick Henry in Virginia Convention). Permanent citations for Elliot's debates may be found at the following locations: volume 2, https://perma.cc/4FKE-NPSD; volume 3, https://perma.cc/FFY9-TBMA; volume 4, https://perma.cc/2DZL-F3LY.

573 Id.; AN Old Whig No. 5, in 3 The COMPLETE ANTIFEDERALisT $\$ 3.3 .25-26$, at 34-35 (Herbert J. Storing \& Murray Dry eds., 1981). 
Almighty God, according to the dictates of their own consciences and understanding. ${ }^{, 574}$

In response, the Constitution's Federalist supporters insisted that a bill of rights was unnecessary (since federal officials would have "no particle of . . . jurisdiction" over subjects like religion and press) and might even be "dangerous" (because it was impossible to enumerate all the rights of individuals, and the failure to mention a particular right would imply that it was not meant to be protected).$^{575}$ But abstract legal arguments of this sort did little to stem the tide of popular support for a bill of rights. As Patrick Henry observed in the Virginia convention, "[i]f you had a thousand acres of land" at stake in a transaction, you would insist that your rights be spelled out in no uncertain terms; and this was all the more true when your "most valuable rights and privileges" were involved..$^{576}$

To overcome such opposition, Madison and some Federalist colleagues expressed a willingness to adopt further protections for rights after the Constitution was ratified. ${ }^{577}$ A number of state conventions put forward such amendments. ${ }^{578}$ The most fully developed proposal on religious liberty came from Virginia:

That religion or the duty which we owe to our Creator, and the manner of discharging it can be directed only by reason and conviction, not by force or violence, and therefore all men have an equal, natural and unalienable right to the free exercise of religion according to the dictates of conscience, and that no particular religious sect or society ought to be favored or established by Law in preference to others. ${ }^{579}$

Four features of this proposal are striking. First, its assertion that religion "can be directed only by reason and conviction" adopts the natural religion language of article 16 of the Virginia Declaration of Rights. ${ }^{580}$ Second, the proposal amplifies that article's natural rights language by asserting that "all

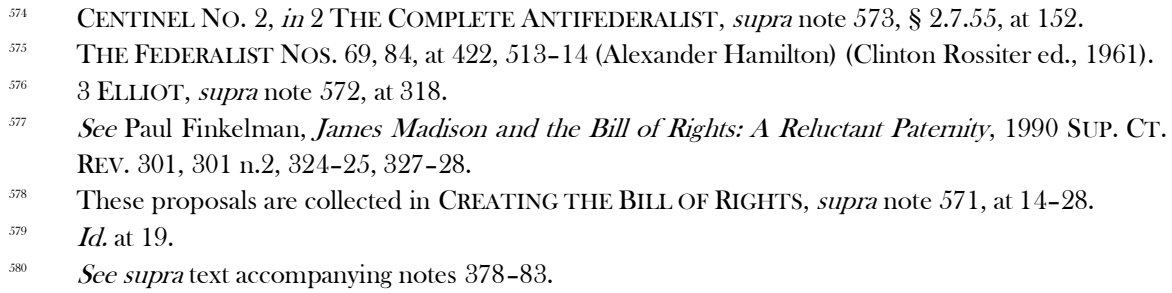


men have an equal, natural, and unalienable right to the free exercise of religion, according to the dictates of conscience." Third, the proposal omits article 16's admonition that all people should practice Christian charity toward one another. Finally, in accord with the events of the mid-1780s, the proposal firmly connects religious liberty with the nonestablishment of religion. ${ }^{581}$

Virginia's proposal was later endorsed by North Carolina and Rhode Island, both of which refused to ratify the Constitution without amendments. ${ }^{582}$ Two other states called for a bill of rights to be added after ratification. New York submitted an amendment declaring "[t]hat the People have an equal, natural and unalienable right, freely and peaceably to Exercise their Religion according to the dictates of Conscience, and that no Religious Sect or Society ought to be favoured or established by Law in preference to others., ${ }^{383}$ New Hampshire would simply have stated that "Congress shall make no Laws touching Religion, or to infringe the rights of Conscience." ${ }^{584}$ Additional proposals on religious liberty came from the delegates who dissented from ratification in Pennsylvania, Massachusetts, and Maryland. ${ }^{555}$ Notably, all the proposals that emerged from the state conventions articulated the principle of religious liberty in general terms, and none made any reference to Christianity. Likewise, while some of the ratifications thanked God for the opportunity to make a national Constitution, they did not use specifically Christian language in this regard. ${ }^{586}$

\section{The Ban on Religious Tests}

Further insight into the conception of religious liberty that informed the Constitution may be found in the debates over the clause in Article VI which obligated all federal and state officials to make an "Oath or Affirmation" to

${ }^{581}$ See supra Part IV.A.

${ }_{582}$ See 4 Elliot, supra note 572, at 242, 244; THE COMPLETE BiLl OF Rights $\$ 1.1 .2 .7$, at 12-13 (Neil H. Cogan ed., 2d. ed. 2015); AKHIL REed AMAR, AMERiCA's Constitution: A BIOGRAPHY 6-7 (2005).

sk3 Creating THe BiLl OF Rights, supra note 571, at 22.

s\$4 Id. at 17.

585 See The COMPLete Bill OF Rights, supra note 582, at 11-12.

See, e.g., 2 ELLIOT, supra note 572, at 176 (ratification by Massachusetts convention "acknowledging, with grateful hearts, the goodness of the Supreme Ruler of the universe"). 
support the Constitution, but which added that "no religious Test shall ever be required as a Qualification to any Office or public Trust under the United States." ${ }^{387}$ The ban on religious tests was adopted unanimously by the Philadelphia Convention despite Roger Sherman's suggestion that the provision was unnecessary in light of "the prevailing liberality" of public sentiment on such matters. ${ }^{588}$ In the state ratifying conventions, some Antifederalists objected that the provision would allow Jews, Catholics, Muslims, Pagans, Deists, and even atheists to hold federal office. ${ }^{589}$ These delegates asserted that "the Christian religion is best calculated, of all religions, to make good members of society, on account of its morality." delegates went so far as to say that "a person could not be a good man without being a good Christian," and that "[a]ll those who have any religion are against the emigration of [non-Christians] from the eastern hemisphere., ${ }^{591}$

The Federalists responded that the Constitution aimed to reject this "intolerant spirit," which had led to "persecutions and wars of the most implacable and bloody nature ... in every part of the world." "592 As the Federalist leader and future Supreme Court Justice James Iredell told the North Carolina convention, America had repudiated the view that "all wisdom" centered in the rulers, and instead had embraced the more "modest[] and reasonabl[e]" view "that a man may be of different religious sentiments from our own, without being a bad member of society." "T93 The ban on religious tests was "calculated to secure universal religious liberty" by making all individuals eligible for office without regard to their beliefs. ${ }^{594}$ Iredell also discussed Omichund v. Barker ${ }^{395}$ the English decision which disavowed the

${ }_{587}$ U.S. CONST. art. VI, cl. 3.

s88 MADisOn, DEBATES, supra note 570 , at 498.

${ }^{389} \quad$ See, e.g., 2 Elliot, supra note 572, at 118, 148 (remarks of Dr. Jarvis and Major Lusk in Massachusetts convention); 4 id. at 191-92, 199, 215 (remarks of Messrs. Henry Abbott, Caldwell, and Lancaster in North Carolina convention).

3904 id. at 199 (remarks of Mr. Caldwell).

${ }_{591} 2$ id. at 119 (remarks of Col. Jones in Massachusetts convention); 4 id. at 199 (remarks of Mr. Caldwell in North Carolina convention).

592 4 id. at 192-93 (remarks of Mr. Iredell in North Carolina convention).

${ }^{593} \quad I d$.

594 Id. at 196.

395 Of the Sufficiency and Disability of a Witness (Omichund v. Barker) (1744) 22 Eng. Rep. 337; 2 Equity Cases Abridged 395. 
notion that only Christian oaths could be relied upon. ${ }^{596}$ As we have seen, this decision rested on the view that the practice of oath-taking is not limited to Christianity but "follows from the Principles of Natural Religion." "977

The idea of natural religion also appeared in other Federalist defenses of the religious test ban. In the Massachusetts convention, the Rev. Daniel Shute observed that he did not limit his "charity and confidence" to his fellow Congregationalists, but instead believed "that there are worthy characters among men of every denomination-among the Quakers, the Baptists, the Church of England, the Papists; and even among those who have no other guide, in the way to virtue and heaven, than the dictates of natural religion. ${ }^{598}$ To disqualify people from public office on account of their religious views would infringe their "civil rights" without conferring any benefit on the public. ${ }^{599}$ The state's future Chief Justice, Theophilus Parsons, added that it was impossible to formulate a religious test in a manner that was neither unacceptably narrow (since no one today "is so illiberal as to wish Ito confine office-holding] to any one sect of Christians") nor so broad as to be meaningless, since the term "Christianity" could be used to describe anything from strict Calvinism to "natural religion." we can have of the sincerity of a man's religion is a good life," and that is what voters should focus on. ${ }^{601}$

In these ways, the ideas of reason and natural religion played a significant part in the Federalist defense of the religious test ban. Christian arguments were made as well. Iredell asserted that " $[\mathrm{t}]$ he divine Author of our religion [that is, Christ] never wished for its support by worldly authority. ${ }^{\circ 02}$ Shute observed that "[t]he apostle Peter tells us that God is no respecter of persons, but, in every nation, he that feareth him, and worketh righteousness, is acceptable to him., ${ }^{\text {,603 }}$ Isaac Backus went furthest in this direction when he told

\footnotetext{
See 4 Elliot, supra note 572, at 197-98.

;97 Omichund, 22 Eng. Rep. at 347; 2 Equity Cases Abridged at 408 (opinion of Hardwicke, C.); supra text accompanying notes 181-86 (discussing this case).

598 2 ELLIOT, supra note 572, at 119 (remarks of Rev. Shute).

s.9. Id. at 118.

(6) Id. at 90 (remarks of Mr. Parsons).

(601 Id.

$6024 \mathrm{id}$. at 194 (remarks of Mr. Iredell in North Carolina convention).

603 2 id. at 119 (remarks of Rev. Shute in Massachusetts convention, quoting Acts 10:35).
} 
the Massachusetts convention that "no man or men can impose any religious test, without invading the essential prerogatives of our Lord Jesus Christ." Yet even Backus rested his position on broader grounds when he appealed to "reason" as well as "the Holy Scriptures" for the principle that "religion is ever a matter between God and individuals" into which the state may not intrude. ${ }^{605}$ In short, while the Federalists offered some Christian rationales for the ban, their defense of "universal religious liberty" ultimately was founded on their view of what reason required. ${ }^{606}$

\section{B. The Free Exercise Clause and the Bill of Rights}

In early 1789, Madison was elected to the First Congress with key support from John Leland and other Virginia Baptist leaders, after assuring them that he believed the Constitution should be amended to protect "all essential rights," including freedom of the press and "the rights of Conscience in the fullest latitude." ${ }^{607}$ Madison strove to make good on this commitment by persuading Congress to approve a bill of rights. The effort was a lonely one, for most Federalists were at best indifferent to the project, while Antifederalists were more interested in fundamentally restructuring the constitutional scheme in order to diminish federal power. ${ }^{608}$ That a bill of rights was adopted was largely due to Madison's perseverance in the face of these obstacles. ${ }^{609}$

On June 8, 1789, Madison presented his proposal to the House of Representatives. His long speech on this occasion offers the greatest insight into the document's meaning and goals. ${ }^{610}$ As he explained, the American

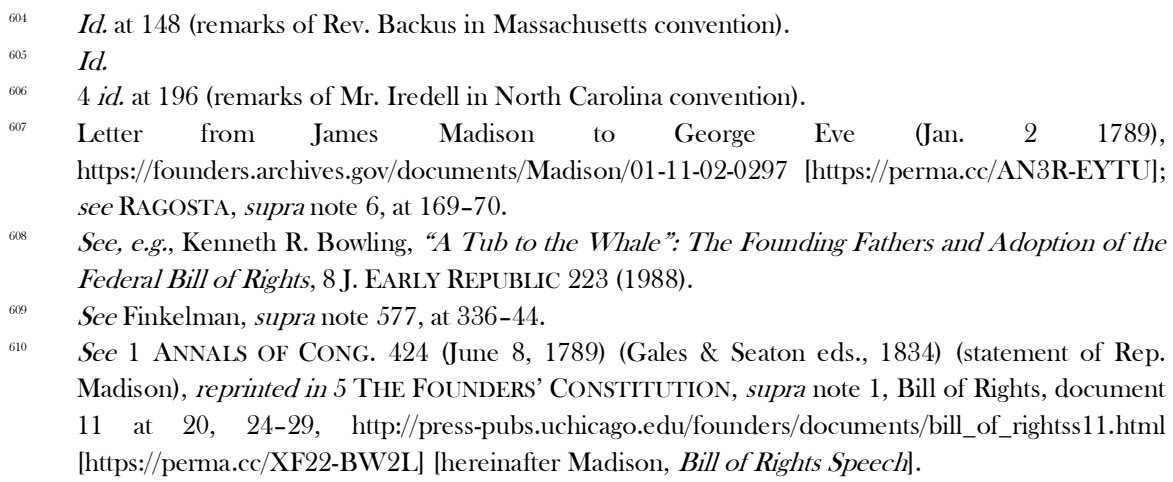


people had come to believe that constitutional barriers should be erected to protect "the great rights of mankind" against abuse of power. ${ }^{611}$ In a democratic society, the most serious danger came not from the executive or even from the legislative branch but from "the body of the people, operating by the majority against the minority." ${ }_{112}$ The state declarations protected several categories of rights, including (1) the "natural right[s]" which the people retain when they establish a government and (2) certain "positive rights" such as trial by jury, which do not exist in a state of nature but which are made part of "[the] social compact" because they are "as essential to secure the liberty of the people as any one of the pre-existent rights of nature."

As Madison's notes for the speech indicate, he regarded liberty of conscience as an inalienable natural right. ${ }^{614}$ To protect this freedom, he proposed to amend the Constitution to provide that "[t]he civil rights of none shall be abridged on account of religious belief or worship, nor shall any national religion be established, nor shall the full and equal rights of conscience be in any manner, or on any pretext, infringed." ${ }^{15}$ Together with his other amendments, this proposal was considered first by a House select committee and then by each chamber. ${ }^{616}$ As finally adopted, it read, "Congress shall make no law respecting an establishment of religion, or prohibiting the free exercise thereof." ${ }^{\text {it }}$

Unfortunately, the congressional debates shed little light on the concrete legal meaning of the Free Exercise Clause. Several broader points do emerge, however. First, religious liberty was regarded as an inalienable natural right. This view was reflected not only in Madison's speech and notes but also in the draft bill of rights prepared by another select committee member, Roger Sherman of Connecticut, who placed "the rights of conscience in matters of




religion" first among the "natural rights which are retained by [the people] when they enter into society."

Their colleagues undoubtedly agreed with this position, which had become widely accepted in American thought. As we have seen, the idea of natural rights was associated with the idea of natural religion. In the words of the Declaration of Independence, natural rights were the rights bestowed on individuals by "the Laws of Nature and of Nature's God." ${ }^{19}$ Thus, the fact that the framers of the Free Exercise Clause saw religious liberty as a natural and inalienable right supports the view that the provision was informed by the concept of natural religion.

Further support for this view can be found in the fact that the framers saw an important connection between freedom of conscience and freedom of expression. These two liberties were treated as inalienable rights both in Madison's notes and in Sherman's draft. ${ }^{620}$ Amendments to protect religious liberty and the freedoms of speech, press, and assembly stood immediately next to one another throughout the drafting process, from Madison's original proposal through the final version of the Bill of Rights, which consolidated all these rights into the First Amendment. ${ }^{621}$ The notion that liberty of conscience and freedom of thought and expression belong together also can be found in

${ }_{618}$ See Roger Sherman's Proposed Committee Report art. 2 (July 21-28, 1789), in Creating THE BiLL OF RigHTS, supra note 571, at 266, 267 [hereinafter Sherman Draft].

619 DECLARATION OF INDEPENDENCE, supra note 372.

620 See Madison, Bill of Rights Notes, supra note 614; Sherman Draft, supra note 618, art. 2, at 267.

${ }^{621}$ See U.S. CONST. amend. I (declaring that "Congress shall make no law respecting an establishment of religion, or prohibiting the free exercise thereof; or abridging the freedom of speech, or of the press; or the right of the people peaceably to assemble ....”); Madison, Bill of Rights Speech, supra note 610 , at 25 ("The people shall not be deprived or abridged of their right to speak, to write, or to publish their sentiments; and the freedom of the press, as one of the great bulwarks of liberty, shall be inviolable. The people shall not be restrained from peaceably assembling and consulting for their common good ... ."); Sherman Draft, supra note 618, at 267; Creating THE Bill OF Rights, supra note 571 , at 38 (version adopted by House); id. at 48 (version adopted by Senate). The two rights were also joined in Madison's proposal to bar the states from "violat[ing] the equal rights of conscience, or the freedom of the press, or the trial by jury in criminal cases." Madison, Bill of Rights Speech, supra note 610, at 25. Although a revised version of this proposal passed the House, it was defeated in the Senate, see Creating the Bill OF Rights, supra note 571, at 41 \& n.19, perhaps on the ground that the Constitution should not impose greater limits on state power than it already did, cf. id. at 188 (remarks of Rep. Tucker). 
many of the writers we have discussed. ${ }^{622}$ It is consistent with the idea that both of these liberties are encompassed within freedom of mind, or the liberty of rational creatures to use their faculties to seek and communicate truth about the most important matters. This view finds classic expression in Jefferson's Bill for religious freedom, which proclaims that because "Almighty God hath created the mind free," all individuals have a right "to profess, and by argument to maintain, their opinions in matters of religion."

A final point concerns the relationship between religious liberty and nonestablishment of religion. Once again, these two ideas were joined together in the text throughout the legislative process. ${ }^{624}$ According to Madison, the ban on establishment was meant to respond to concerns that had been raised during the ratification debates by providing that "congress should not establish a religion, and enforce the legal observation of it by law, nor compel men to worship God in any manner contrary to their conscience.” ${ }^{625}$ Of course, it is clear that, in Madison's words, a law of this sort would "infringe the rights of conscience," and no one in the House debates disputed this view. ${ }^{626}$ But there was no consensus beyond that point. Some members, like Daniel Carroll of Maryland, maintained that "the rights of conscience" were so delicate that they could not "bear the gentlest touch of the governmental hand, ${ }^{, 227}$ while others, including Peter Silvester of New York and Benjamin Huntington of Connecticut, feared that if such a ban were interpreted broadly it would "have a tendency to abolish religion altogether." ${ }^{628}$ As Madison's

622 See, e.g., Locke, Human Understanding, supra note 19, bk. IV, ch. XX, §4, at 708 (condemning laws that seek to protect "the Religion of the Country" by denying people "the Liberty and Opportunities of a fair Enquiry," thereby "enslav[ing individuals] in that which should be the freest part of Man, their Understandings”); Price, Observations, supra note 245, at 124-37 (defending "liberty of discussion in all speculative matters, and liberty of conscience in all religious matters"); 1 CATO's LETTERS, supra note 351, vol. 2, NO. 62, at 428-29 (asserting that rulers act tyrannically when they attempt to regulate individuals' thoughts and opinions regarding religion and other subjects).

${ }^{623} \quad$ Jefferson Bill, supra note 469.

624 Madison, Bill of Rights Speech, supra note 610, at 25 (provision as introduced); CreATING THE BILl OF RighTS, supra note 571, at 38 (version adopted by House); id. at 48 (version adopted by Senate); U.S. CONST. amend. I (final version).

${ }^{625}$ Creating THe Bill of Rights, supra note 571, at 157-58 (remarks of Rep. Madison).

${ }^{626} \quad$ Id. at 158.

${ }^{627} \quad$ Id. at 157 (remarks of Rep. Carroll).

Id. (remarks of Rep. Sylvester); see id. at 158 (remarks of Rep. Huntington). 
Memorial indicates, he himself believed that government had no legitimate authority at all in the religious domain. ${ }^{62}$

In the end, Congress did not attempt to resolve this issue. One reason is obvious: as Madison repeatedly emphasized, constitutional amendments could achieve the supermajority required for adoption only if they were drafted in the form of general principles that commanded broad assent. ${ }^{630}$ Accordingly, while the First Amendment prohibited federal laws respecting an establishment of religion, it did not specify what that meant.

\section{RELIGIOUS EXEMPTIONS FROM CIVIL LAWS}

\section{A. Background}

In this Article, I have argued that the central view that informed the Free Exercise Clause was neither secular liberalism nor Evangelicalism, but natural religion and natural rights. This view has a bearing on many of the doctrinal questions that arise under the Clause today. In this Part, I briefly explore what this view can teach us about the original understanding on one of the most important issues: whether the Free Exercise Clause gives individuals a constitutional right to exemption from civil laws that conflict with their religious beliefs.

The Supreme Court has long grappled with this problem. Nearly a century and a half ago, Reynolds $v$. United States ${ }^{631}$ held that the right to free exercise did not excuse one from the duty to comply with civil laws. ${ }^{632}$ In 1963, the Court reversed course in Sherbert v. Verner ${ }^{633}$ and ruled that when a general law has the incidental effect of substantially burdening a person's religious practice, the law can be applied to that person only if the government is able

See supra text accompanying notes $442-46$.

See Creating THE Bill OF Rights, supra note 571, at 167-68, 176, 200 (remarks of Rep. Madison); Steven J. Heyman, Ideological Conflict and the First Amendment, 78 CHI. KENT L. REV. 531, 544-46 (2003).

98 U.S. 145 (1879).

632 See id. at 164, 166-67 ("Laws are made for the government of actions, and while they cannot interfere with mere religious belief and opinions, they may with practices.”).

374 U.S. 398 (1963). 
to satisfy strict scrutiny. ${ }^{634}$ In Employment Division v. Smith, ${ }^{635}$ however, the Court effectively repudiated this approach and reverted to the Reynolds position. ${ }^{636}$ In turn, this led Congress in 1993 to adopt the Religious Freedom Restoration Act (RFRA), which took issue with Smith and sought to restore the Sherbert standard. ${ }^{637}$ In City of Boerne v. Flores, ${ }^{638}$ the Court reaffirmed Smith and struck down RFRA as applied to the states. But the statute continues to apply to the federal government itself, ${ }^{639}$ and many states have adopted RFRAs of their own. ${ }^{60}$ In recent years, the problem of religious exemptions has only become more controversial as individuals and businesses have challenged laws that required them to provide contraception to their employees or to refrain from discriminating against same-sex couples. ${ }^{611}$

634 See id. at 406 .

698 U.S. $872(1990)$.

636 $\quad$ See id. at 878-80.

637 Religious Freedom Restoration Act (RFRA) of 1993, 42 U.S.C. $\$ \S 2000 b b-2000 b b-4$ (2015) (declaring in \$ 2(b) (1), 42 U.S.C. \$2000bb(b) (1), that the Act seeks "to restore the compelling interest test as set forth in Sherbert v. Verner, 374 U.S. 398 (1963) and Wisconsin v. Yoder, 406 U.S. 205 (1972) and to guarantee its application in all cases where free exercise of religion is substantially burdened").

521 U.S. 507 (1997).

639 See Gonzales v. O Centro Espirita Beneficente Uniao do Vegetal, 546 U.S. 418 (2006).

6* See State Religious Freedom Restoration Acts, NAT'L CONFERENCE OF STATE LegisLatures, https://www.ncsl.org/research/civil-and-criminal-justice/state-rfra-statutes.aspx

[https://perma.cc/PW8K-64LV] (last visited Nov. 30, 2020) (observing that "[s]ince 1993, 21 states have enacted state RFRAs").

6st See, e.g., Masterpiece Cakeshop, Ltd. v. Colo. Civil Rights Comm'n, 138 S. Ct. 1719 (2018) (ruling that the commission violated the Free Exercise Clause by failing to impartially consider whether an exemption should be accorded to a baker who refused on religious grounds to make a wedding cake for a same-sex couple); Burwell v. Hobby Lobby Stores, Inc., 573 U.S. 682 (2014) (holding that a federal regulation requiring companies to provide health-insurance coverage for certain methods of contraception violated the federal RFRA); Fulton v. City of Phila., 922 F.3d 140 (3d Cir. 2019) (determining that the city had not contravened the First Amendment rights of a religious organization that refused to vet same-sex couples to become foster parents because the City had applied its nondiscrimination policy neutrally), cert. granted, 104 S. Ct. 1104 (Feb. 24, 2020) (No. 19-123). 


\section{B. General Views on a Right to Religious Exemption During the Founding Era}

Although the majority opinion in Smith was authored by Justice Antonin Scalia, a leading originalist, it made no effort to explore the founders' views. ${ }^{612}$ In a long and provocative article, Michael W. McConnell sharply criticizes the Smith position on originalist grounds. ${ }^{6+3}$ Drawing upon what I have called the revisionist historical view, McConnell argues that the Free Exercise Clause should be understood not in terms of the "Enlightenment" rationalism of Locke and Jefferson, but rather in terms of a view that accorded much greater protection to religion. ${ }^{64}$ McConnell contends that this broader view was championed not only by the Evangelicals but also by Madison. ${ }^{645}$ At the outset of his Memorial and Remonstrance, Madison invoked article 16 of the Virginia Declaration of Rights to argue that everyone has a right to exercise religion in accord with "conviction and conscience." ${ }^{646}$ "This right," he continued,

is in its nature an unalienable right. It is unalienable, because the opinions of men, depending only on the evidence contemplated by their own minds cannot follow the dictates of other men: It is unalienable also, because what is here a right towards men, is a duty towards the Creator. It is the duty of every man to render to the Creator such homage and such only as he believes to be acceptable to him. This duty is precedent, both in order of time and in degree of obligation, to the claims of Civil Society. Before any man can be considered as a member of Civil Society, he must be considered as a subject of the Governour of the Universe: And if a member of Civil Society, who enters into any subordinate Association, must always do it with a reservation of his duty to the General Authority; much more must every man who becomes a member of any particular Civil Society, do it with a saving of his allegiance to the Universal Sovereign. We maintain therefore that in matters of Religion,

612 See Emp't. Div., Dep't. of Human Res. of Or. v. Smith, 494 U.S. 872, 878-80 (1990) (relying on precedent, rather than original understanding, to support its holding).

6 McConnell, supra note 6. A persuasive critique of McConnell's historical position may be found in Philip A. Hamburger, A Constitutional Right of Religious Exemption: An Historical Perspective, 60 Geo. WASH. L. Rev. 915, 916 (1992) [hereinafter Hamburger, Exemption]. For a particularly thoughtful and nuanced assessment of the historical evidence, see KATHLEEN A. Brady, ThE DistinCtivenESS OF RELIGION IN AMERICAN LAW 116-22, 159-65, 214 (2015).

6it McConnell, supra note 6, at 1452-55.

6his See id. at 1453

6 Madison, Memorial, supra note 440, $\$ 1$. 
no mans right is abridged by the institution of Civil Society and that Religion is wholly exempt from its cognizance. ${ }^{647}$

According to McConnell, this passage "suggests an approach toward religious liberty consonant with" an entitlement to religious exemptions. "If the scope of religious liberty is defined by [an individual's own understanding of his] religious duty," McConnell reasons, "and if the claims of civil society are subordinate to the claims of religious freedom, it would seem to follow that the dictates of religious faith must take precedence over the laws of the state, even if they are secular and generally applicable." ${ }^{649}$ Dissenting in City of Boerne, Justice Sandra Day O'Connor adopts this reading of Madison and uses it to argue that the original understanding supports mandatory religious exemptions. $^{650}$

A little reflection, however, shows that this could hardly have been what Madison meant. The position that he takes in the Memorial is absolute: "in matters of Religion, no mans right is abridged by the institution of Civil Society and ... Religion is wholly exempt from its cognizance." ${ }^{651}$ If, as McConnell and O'Connor believe, this position should be understood to refer to religious exemptions, the result would be an extraordinarily broad privilege to disobey the law on grounds of conscience. For instance, no one who had a religious objection to paying taxes would be obliged to do so. There is no reason to believe that Madison held this view.

The problem with the McConnell-O'Connor interpretation is that it overlooks the political dispute that the Memorial was meant to address, and instead applies that document's reasoning to a very different issue. The Memorial was directed against Henry's bill to institute a tax for the support of the Christian religion. ${ }^{652}$ The petition's first section argued that when

\footnotetext{
6677 Id.

${ }_{618} \quad$ McConnell, supra note 6, at 1453.

Id $\quad$ Id.

650 City of Boerne v. Flores, 521 U.S. 507, 560-61 (1997) (O'Connor, J., dissenting); see also Church of the Lukumi Babalu Aye, Inc. v. City of Hialeah, 508 U.S. 520, 574-76 (1993) (Souter, J., concurring in part and in the judgment) (calling McConnell's account "strong"). The petitioners who are urging the Court to overrule Smith this Term also rely extensively on McConnell's scholarship. See Brief for Petitioners at 42-47, Fulton v. City of Phila., 922 F.3d 140 (3d Cir. 2019) (No. 19-123).

${ }_{651}$ Madison, Memorial, supra note 440, $\$ 1$ (emphasis added).

${ }_{652} \quad$ See supra text accompanying notes $432-41$.
} 
individuals enter the social contract, they grant civil society no authority whatever over religious matters, and so the government has no power to tax the people for such purposes. The argument is not that religious liberty imposes limits on the government's authority to make laws on civil matters, but that the government has no business legislating on religious ones. This insistence that religion and state are separate realms cuts against the view that religious believers can demand exemption from civil laws. Indeed, the only part of the Memorial that explicitly mentions exemptions criticizes them for drawing improper distinctions between religious groups. ${ }^{6.33}$

These observations point toward a broader understanding of the lateeighteenth-century movement to promote religious liberty. The movement's main objective was not to seek exemptions from the state's laws but to draw clear boundaries between the religious and civil realms. ${ }^{651}$ As Baptists put it in the most widely subscribed petition against the Assessment Bill, "Let religious Societies Manage the affairs of Religion and [let] Government exercise it's Concern about the Civil Right and Temporal privileges of Man." ${ }^{\text {"555 }}$ In support of this view, Evangelicals cited scriptures asserting that Christ's kingdom is not of this world ${ }^{656}$ and distinguishing between the claims of God and Caesar. ${ }^{657}$ As we have seen, many Evangelicals also were willing to employ the language of natural rights. ${ }^{6.58}$ Indeed, they needed to do so to pursue a second main objective of the movement: ensuring that the members of all religious groups enjoyed equal rights within the commonwealth. ${ }^{69}$

This is the language that Madison uses in the first section of the Memorial. He begins by quoting article 16's articulation of the core principle of natural

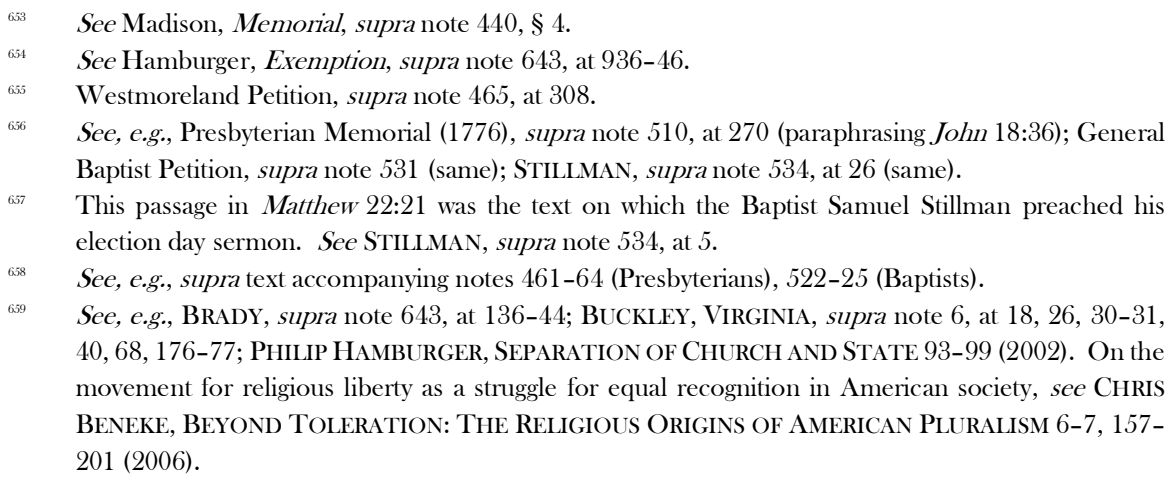


religion: that "Religion ... can be directed only by reason and conviction, not by force or violence. ${ }^{{ }^{60} 0}$ Echoing Locke and other writers in this tradition, he then explains that religious liberty is an inalienable right and that civil society and government have no legitimate power over religion. ${ }^{661}$

On this Lockean view, religion and civil society constitute two fundamentally different spheres. ${ }^{662}$ The latter is devoted to promoting the temporal interests of individuals, which includes protecting their natural and civil rights. ${ }^{63}$ Although the state is empowered to use force for this purpose, it may not intrude into the religious realm, within which individuals must be free to believe and worship according to conscience. ${ }^{64}$ Civil society is concerned with life in this world, while religion is concerned with life in the world to come. ${ }^{665}$ The key to protecting religious liberty is to maintain a clear distinction between these two spheres. ${ }^{666}$

The difficulty with this position, as Locke himself recognizes, is that there is an important overlap between the religious and civil realms. Although belief and worship clearly fall on one side of the line and matters like property on the other, both domains are concerned with the way that individuals live their lives, for their "Moral Actions" affect the common good as well as their prospects for eternal salvation. ${ }^{67}$ This raises the possibility of conflict between the two spheres. ${ }^{668}$ From the perspective of Locke and natural religion, however, there is no inherent tension between them. God is the source of physical as well as spiritual life. Both realms are governed by the law of nature, which enjoins individuals to live a "Good Life." ${ }^{699}$ The state is responsible for enforcing that part of natural law which obliges individuals to respect the

Gro Madison, Memorial, supra note 440, 11 (quoting VA. DeClaration OF Rights, supra note 1, art. $16)$.

See id. ("II]n matters of Religion, no mans right is abridged by the institution of Civil Society and . . . Religion is wholly exempt from its cognizance.").

602 See LOCKE, TOLERATION, supra note 41, at 11-12, 24.

See id. at 12.

Got See id. at 12-15.

665 $\quad$ See id. at 45-48.

606 See id. at 11-12.

667 Id. at 45.

See id.

id. 
natural and civil rights of others. ${ }^{670}$ Religion is concerned not only with individuals' conduct toward one another but also with their obligations toward God. ${ }^{671}$ All these duties are founded upon reason. ${ }^{672}$ Thus, from the standpoint of natural religion, there is an essential harmony between the civil and religious spheres. So long as the state's laws are consistent with natural law, they also will be compatible with the rights and duties of individuals under natural religion.

Natural law also provides a basis for resolving any conflicts that do arise between religious exercise and civil law. On one hand, the state is bound to use its power in conformity with the law of nature, and so it cannot legitimately make laws that conflict with the natural right to religious freedom. ${ }^{673}$

On the other hand, this view also sets bounds to that freedom. The same law of nature that protects the religious liberty of individuals also requires them to use it in a manner that respects the rights of others. ${ }^{67}$ Those rights fall into several categories. The first is religious liberty itself: individuals who assert a right to freely practice their own religion must permit others to do likewise. ${ }^{675}$ A second category comprises other natural rights such as life, liberty, and property. Thus, a religious ritual would not be entitled to protection if it involved child sacrifice, for that would violate the victim's right to life as well as the natural law against murder. ${ }^{676} \mathrm{~A}$ third category consists of the rights that individuals possess as citizens and that derive from the social contract or the laws of society, such as the rights to vote and to be eligible for office. ${ }^{67}$ Although these rights do not arise from the law of nature itself, they are entitled to protection under that law, which forbids individuals to harm others by violating their rights. ${ }^{678}$ In return for the benefits that individuals receive under the social contract, they also assume certain positive duties toward the

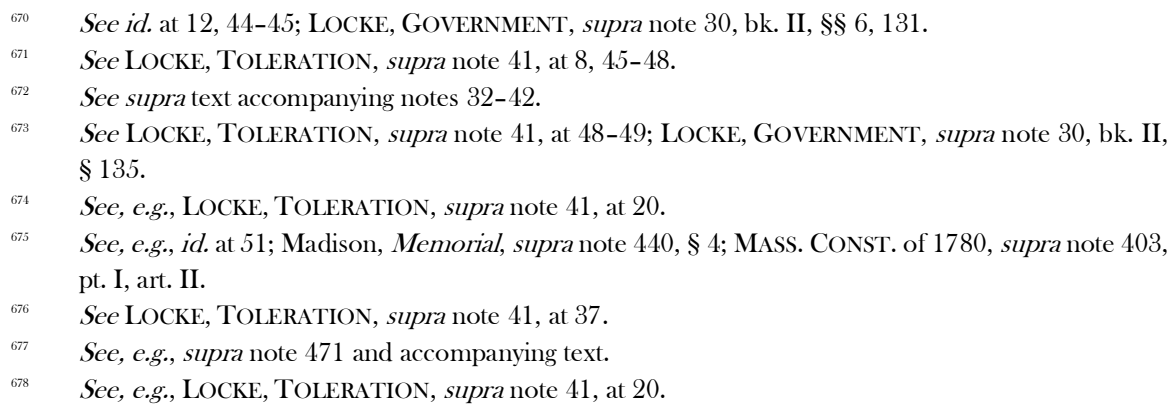


community, such as the obligation to pay taxes. ${ }^{679}$ Again, while these duties do not derive from natural law itself, they nonetheless are binding under that law, which requires individuals to keep their promises, including the ones they make in the social contract. ${ }^{680}$ At least as a general matter, the right to religious liberty does not exempt individuals from these duties of citizenship. ${ }^{681}$ Still less does it exempt them from their most fundamental duty to the communitythe obligation to keep the peace by obeying the laws that are meant to protect the basic rights of other individuals. ${ }^{682}$

In short, founding-era Americans understood religious liberty within a broader framework established by natural law and the social contract. Within the religious sphere, individuals are free to believe and worship according to conscience without interference by the state. But religious liberty does not give one a right to violate civil laws that are adopted to enforce the duties that one owes to other people, such as the obligation to respect the natural, civil, and religious rights of individuals and the peace of the community.

On the Lockean view, the main function of the state is to establish and enforce laws of this sort. ${ }^{633}$ But the state also has the authority to pass positive laws for the promotion of economic well-being and other aspects of the public good ${ }^{684}$ Suppose that a public welfare law of this sort requires individuals to act in a way that conflicts with what some believe to be a positive law revealed by God. In this case, does the right to religious liberty excuse them from their duty to comply with the civil law?

In a Letter Concerning Toleration, Locke decisively rejects this position. Instead, he maintains that while matters of belief and worship are reserved to individuals and churches, civil matters are the province of the state. ${ }^{685}$ Under the social contract, the government is empowered to make laws not only to protect the private rights of individuals but also to promote "the Temporal Good and outward Prosperity of the [whole] Society." ${ }^{\text {"686 }}$ The government has no authority to interfere with an individual's own judgment in religious matters,

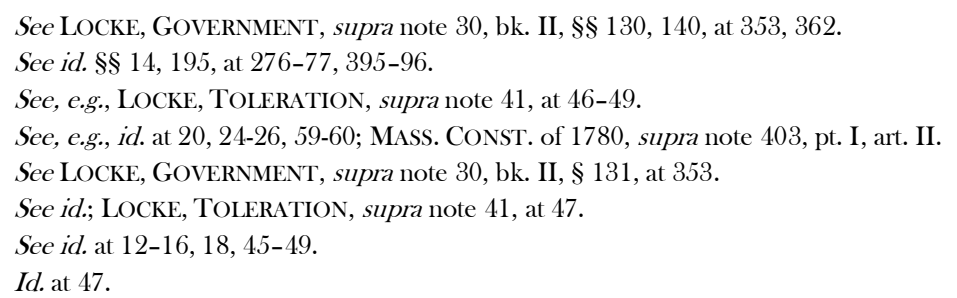


but that judgment does not relieve him of the obligation to comply with "a Law enacted in Political Matters, for the publick Good." ${ }^{967}$

This does not mean that Locke holds that the claims of civil society are superior to those of religion. On the contrary, he maintains that because nothing is more important to individuals than attaining "eternal Salvation," the duty to follow God's will is "the highest Obligation that lies upon Mankind." Thus, "Obedience is due in the first place to God, and afterwards to the Laws. ${ }^{\text {" }}{ }^{99}$ But people's lives in this world are also given by God, who ordained civil society and government for their preservation and well-being. ${ }^{690}$ It lies with government to determine what laws should be made for these purposes. These laws are binding on all: as Locke observes in another context, it is a fundamental principle that "No Man in Civil Society can be exempted from the Laws of it." ${ }^{991}$ If one truly believes that a law conflicts with God's will, one should follow one's conscience and refuse to obey the law; but at the same time one must be willing to accept the legal consequences. ${ }^{692}$ Both the religious and the civil realms ultimately derive from God's will, and so one cannot properly invoke one's religious convictions to override one's civil obligations. Instead, the laws should apply equally to all individuals without regard to their spiritual beliefs or the motives for their conduct. ${ }^{693}$ For example, if people may lawfully slaughter calves, they must be permitted to sacrifice them for religious purposes. ${ }^{694}$ But if the public good requires a moratorium on the killing of livestock which have been decimated by a plague, the belief that one has a religious duty to perform a sacrifice does not entitle one to an exemption. ${ }^{695}$

In this way, Locke makes a powerful case against a right to religious exemptions from civil laws. It is difficult to find any general, theoretical statement on the other side. As I have indicated, Madison's Memorial does not constitute such a statement. ${ }^{696}$ The passage that we examined simply argues

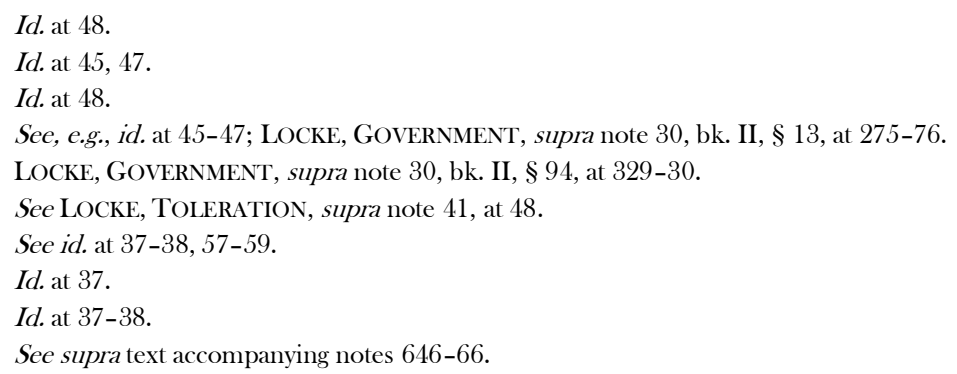


that government has no jurisdiction over religion because free exercise is an inalienable right, and it does so on the basis of the same premises (for example, that one's highest obligation is to obey God) that appear in the writings of Locke and other writers who clearly reject a right to religious exemption. ${ }^{697}$

Yet whether or not the Lockean position was convincing in theory, there were situations in which religious minorities made claims that many foundingera Americans found appealing. The clearest example is the demand by Quakers and other pacifists for exemption from the duty of citizens to serve in the militia-an issue that led to spirited debate during this period.

\section{The Congressional Debates over Religious Exemption from Militia Duty}

\section{The Debate over the Bill of Rights}

The Quakers and other sects had a strong religious commitment to pacifism. ${ }^{698}$ During the ratification debates, three state conventions urged that the Constitution be amended to provide "[t]hat any person religiously scrupulous of bearing arms ought to be exempted, upon payment of an equivalent to employ another to bear arms in his stead." ${ }^{999}$ These proposals

697 As we have seen, for example, Madison's argument echoes one found in the Essay on Toleration by the dissenting minister Philip Furneaux. See supra note 445. In another work, Furneaux explains that while the Protestant dissenters believe that one must "obey God rather than men," Acts 5:29, there is nothing in this sentiment, in the smallest degree, inconsistent with civil obedience: "rendering unto God the things which are God's," is no objection to "rendering unto Caesar the things which are Caesar's." The Dissenters are so far from setting up the supposed interests of religion ... against lawful magistracy, or the peace and good order of society, that they allow the exemption of none from the authority of the civil magistrate; holding all to be equally under his jurisdiction; and that no plea of a sacred character, or of religion and conscience, is to be admitted in bar to his procedure, in matters of a criminal, or merely civil nature.

FuRNEAUX, LeTTERS, supra note 169, Letter VII, at 211 (quoting Matthew 22:21).

See, e.g., FrOST, supra note 393, at 29-43, 62-69.

699 Creating The Bill of Rights, supra note 571, at 19 (Virginia); The COMPlete Bill OF Rights, supra note 582, § 4.1.2.5, at 182 (North Carolina); 1 ELLIOT, supra note 572, at 335 (Rhode Island). The Maryland minority proposed a similar amendment. See The Complete Bill of Rights, supra note $582, \S 4.1 .2 .1$, at 181 . For an insightful discussion of the debates over whether to include such a provision in the Bill of Rights, see Victor Philip Muñoz, The Original Meaning of the Free Exercise Clause: The Evidence from the First Congress, 31 HaRv. J.L. \& PuB. POL'y 1083, 1109-19 (2008). 
resembled the protections found in five state constitutions. ${ }^{700}$ Madison incorporated such a provision in his draft of what became the Second Amendment. ${ }^{701}$ As reported by the House select committee, that amendment read: "A well regulated militia, composed of the body of the people, being the best security of a free state, the right of the people to keep and bear arms shall not be infringed; but no person religiously scrupulous shall be compelled to bear arms., ${ }^{702}$

During the House debates, Elias Boudinot of New Jersey supported the proposed exemption on the ground that there could be no "justice ... in compelling [individuals] to bear arms, when, if they are honest men they would rather die than use them." ${ }^{903}$ Some of his colleagues responded that it would be unjust to require some members of the community to defend others unless the latter were obliged to pay an equivalent. ${ }^{704}$ Other representatives contended that the issue of religious exemptions should be left to the legislature. ${ }^{705}$ As Egbert Benson of New York put it, "No man can claim this indulgence of right. It may be a religious persuasion, but it is no natural right, and therefore ought to be left to the discretion of the Government." House narrowly rejected a motion to strike out the religious exemption clause ${ }^{707}$ but amended it to provide that conscientious objectors should not be compelled to bear arms "in person," thereby giving the legislature the option of requiring them to pay an equivalent. ${ }^{708}$ In the end, however, the religious exemption clause was rejected by the Senate and did not become part of the Bill of Rights. ${ }^{709}$

700 See Muñoz, supra note 699, at 1110 n. 140 (citing constitutions of Delaware, Pennsylvania, New Hampshire, New York, and Vermont).

701 See Creating THE Bill of Rights, supra note 571, at 12 (providing that "no person religiously scrupulous of bearing arms, shall be compelled to render military service in person").

$702 \quad$ Id. at 182.

$703 \quad$ Id. at 198-99.

${ }^{704}$ See, e.g., id. at 183 (remarks of Rep. Jackson).

705 See id. at 183 (remarks of Rep. Sherman); id. at 184 (remarks of Rep. Benson); id. at 198 (remarks of Rep. Scott).

${ }^{706}$ Id. at 184 (remarks of Rep. Benson).

707 Id. The vote was $24-22$. Id.

708 Id. at 199.

$7 *$ See id. at 39 n.13. 


\section{The Debate over the Militia Bill of 1790-91}

During the winter of 1790-91, the First Congress took up a bill to organize the militia. In a rich debate that has attracted little attention in the free exercise literature, the House once again struggled with the problem of conscientious objection to militia service. ${ }^{710}$

On December 22, 1790, Madison proposed that the bill exempt "persons conscientiously scrupulous of bearing arms." "11 In an eloquent speech, he declared that it was "the glory of this country, the boast of the revolution, and the pride of the present constitution, that here the rights of mankind are known and established" more fully than ever before. ${ }^{712}$ This was especially true of "the rights of conscience." "13 Even if the rights involved were less clear, the Quakers had shown themselves to be "deserving of [this] high privilege" because they had long generously extended religious liberty to everyone within their own settlements in Pennsylvania and elsewhere. ${ }^{71}$ Finally, as a practical matter, Congress could not force the Quakers to fight, and so it should "make a virtue of this necessity, and grant the exemption." should be required to pay money instead, Madison's own view was that the exemption should be granted "on terms perfectly gratuitous," if this could be done "with justice to the other sects in the community, or if the other sects were willing to withdraw their plea for an equivalent."

Madison's proposal drew strong criticism from several of his colleagues, including James Jackson of Georgia, William B. Giles of Virginia, Michael J. Stone of Maryland, William L. Smith of South Carolina, and Thomas Scott of Pennsylvania. They argued that under the social contract every individual was entitled to protection by the community and in return owed a duty to aid

710 The fullest account of these debates may be found in the Pennsylvania Packet, and Daily Advertiser in December 1790 [hereinafter Pennsylvania Packet] and its successor newspaper, Dunlap's Am. Daily Advertiser in early January 1791 [hereinafter Dunlap's]. Madison's contributions are reproduced in his collected papers. See infra notes 711, 730-31.

${ }^{71}$ Militia, [22 December] 1790, https://founders.archives.gov/documents/Madison/01-13-02-0245 [https://perma.cc/KGY7-FK3F] (remarks of Rep. Madison).

$712 \quad I d$.

$713 \quad$ Id.

${ }_{74} \quad I d$

${ }_{715} \quad$ Id

$716 \quad I d$. 
in the common defense. ${ }^{717}$ The burdens of this effort should be borne by all alike. ${ }^{718}$ One of the "glories of the American revolution [was] that all religions were put on a level." ${ }^{719}$ It would be unjust, or even unconstitutional, to discriminate in favor of particular groups based on their religious beliefs. ${ }^{720}$ Moreover, if the government began to draw such distinctions, there would be no logical stopping point; for instance, individuals who objected to militia service might also balk at paying taxes for military purposes. ${ }^{721}$

The most interesting response to these arguments came from Boudinot, who maintained that when Americans entered into a new "social compact" during the Revolution, they had embraced the Quakers with full knowledge of their pacifist beliefs and without insisting that they perform military service. ${ }^{722}$ In this way Americans had implicitly "established the principle, that [the Quakers] should be taken into our society with all their privileges and rights as men; among which were acknowledged the rights of conscience. ${ }^{, 233}$ It would be wrong to break "this tacit engagement" by denying them "an indulgence, which they have been in the habit of receiving, and which custom has rendered in some degree sacred to them., ${ }^{724}$

717 See, e.g., Pennsylvania Packet, supra note 710 (Dec. 28, 1790) (remarks of Rep. Jackson on Dec. 22); Dunlap's, supra note 710 (Jan. 1, 1791) (remarks of Rep. Giles on Dec. 22, 1790); Dunlap's, supra note 710 (Jan. 7, 1791) (remarks of Rep. Stone on Dec. 24, 1790). For an account of the reciprocal relationship between the right to protection and the duties of citizens within social contract theory and American constitutionalism, see Steven J. Heyman, The First Duty of Government: Protection, Liberty, and the Fourteenth Amendment, 41 Duke L.J. 507 (1991).

718 See, e.g., Pennsylvania Packet, supra note 710 (Dec. 28, 1790) (remarks of Rep. Jackson on Dec. 22, 1790); Dunlap's, supra note 710 (Jan. 4, 1791) (remarks of Rep. Smith of South Carolina on Dec. 23, 1790); Dunlap's, supra note 710 (Jan. 7, 1791) (remarks of Rep. Stone on Dec. 24, 1790).

719 Dunlap's, supra note 710 (Jan. 10, 1791) (remarks of Rep. Scott on Dec. 24, 1790); see also Dunlap's, supra note 710 (Jan. 5, 1791) (remarks of Rep. Jackson on Dec. 24, 1790) ("The constitution places all religions on an equal footing ....”).

720 See, e.g., Pennsylvania Packet, supra note 710 (Dec. 31, 1790) (remarks of Rep. Jackson on Dec. 22, 1790); Dunlap's, supra note 710 (Jan. 1, 1791) (remarks of Rep. Giles on Dec. 22, 1790); Dunlap's, supra note 710 (Jan. 5, 1791) (remarks of Rep. Jackson on Dec. 24, 1790); Dunlap’s, supra note 710 (Jan. 7, 1791) (remarks of Rep. Stone on Dec. 24, 1790).

${ }^{2} 1$ See, e.g., Dunlap's, supra note 710 (Jan. 4, 1791) (remarks of Rep. Smith of South Carolina on Dec. 23, 1790); Dunlap's, supra note 710 (Jan. 7, 1791) (remarks of Rep. Stone on Dec. 24, 1790).

722 See Dunlap's, supra note 710 (Jan. 4, 1791) (remarks of Rep. Boudinot on Dec. 23, 1790).

${ }_{723}$ Id.

${ }^{724} \quad I d$. 
Despite these differing views, there also were important points of agreement. On one side, the critics of exemptions recognized that actually compelling pacifists to bear arms would impact their rights of conscience and did not insist that this should be done..$^{725}$ As Scott put it, although "every man owes equal duties to the community," it was not "necessary, that every man should discharge that debt in the same manner." ${ }^{\text {"20 }}$ Instead, money could be accepted in lieu of personal service. ${ }^{727}$ On the other side, Madison and his allies recognized that a purely gratuitous exemption might be considered unjust to other sects. ${ }^{728}$ At one point, a consensus appeared to be emerging that the bill should exempt pacifists who paid an equivalent. ${ }^{729}$ On December 23, Madison introduced a new amendment to that effect. ${ }^{730}$ Ultimately, however, compromise proved impossible to reach, and that amendment was voted down 39 to $10{ }^{731}$

\section{Conclusion}

The defeat of Madison's amendment should not be taken to show overwhelming congressional opposition to the idea of conscientious exemption from military service, for many members were concerned with such issues as how the amendment was drafted, ${ }^{732}$ how the government could screen out fraudulent claims for exemption, ${ }^{733}$ and whether militia regulation simply should be left to the states. ${ }^{734}$ The fact remains, however, that during

${ }_{725}$ See, e.g., Pennsylvania Packet, supra note 710 (Dec. 31, 1790) (remarks of Rep. Jackson on Dec. 22, 1790); Dunlap’s, supra note 710 (Jan. 1, 1791) (remarks of Rep. Giles on Dec. 22, 1790).

${ }_{726}$ Dunlap's, supra note 710 (Jan. 10, 1791) (remarks of Rep. Scott on Dec. 24, 1790).

${ }_{727}$ See id. (remarks of Rep. Scott on Dec. 24, 1790).

${ }^{728}$ See, e.g., Militia, supra note 711 (remarks of Rep. Madison on Dec. 22, 1790).

729 See Dunlap’s, supra note 710 (Jan. 1, 1791) (remarks of Rep. Smith on Dec. 22, 1790).

730 Militia, $[23$ December] 1790, https://founders.archives.gov/documents/Madison/01-13-02-0246 [https://perma.cc/ZDU2-UP46].

${ }_{731}$ See Dunlap's, supra note 710 (Jan. 10, 1791) (debate of Dec. 24, 1790). In the end, Congress failed to pass a bill to organize the militia that year. See Militia, [24 December] 1790, https://founders.archives.gov/documents/Madison/01-13-02-0248 (editor's note)

[https://perma.cc/6HCF-H94D]. When Congress finally did so the following year, it left the issue of conscientious exemption to the states. See Second Militia Act \$2, 1 Stat. 271, 272 (1792).

732 See, e.g., Dunlap's, supra note 710 (Jan. 6, 1791) (remarks of Rep. Laurance on Dec. 24, 1790).

739 See, e.g., id.

See, e.g., Dunlap’s, supra note 710 (Jan. 5, 1791) (remarks of Rep. Livermore on Dec. 24, 1790). 
the militia-bill debates Madison and his allies were unable to persuade a majority to endorse such an exemption even in principle. The same is true of the debates over what became the Second Amendment. ${ }^{735}$

Remarkably, in neither of these disputes did anyone suggest that the Free Exercise Clause itself would require such an exemption. ${ }^{736}$ As we have seen, the legislative history of that Clause contains no persuasive evidence that it was understood to mandate religious exemptions from generally applicable laws. ${ }^{737}$ Nor during this period can one find general theoretical arguments that the right to religious liberty requires such exemptions. ${ }^{738}$ On the contrary, leading writers like Locke, Furneaux, and Leland clearly repudiated this position. ${ }^{739}$

\section{Some Implications for Contemporary Free Exercise Doctrine}

\section{Religious Exemptions from Public Welfare Laws}

For these reasons, it cannot be convincingly demonstrated that the original understanding of the Free Exercise Clause points toward a constitutional rule that mandates religious exemptions to religiously neutral laws. As a nonoriginalist, I do not believe that this should necessarily preclude the Supreme Court from adopting such a rule today. ${ }^{70}$ Reasonable arguments can be, and have been, made on both sides as to whether the government should be required to meet some form of heightened review before it can apply a general public welfare law in a manner that imposes a substantial burden on the practice of a minority religion, as the peyote ban did in Employment Division v. Smith. ${ }^{741}$ Although the history does not show that founding-era Americans

See supra Part VI.C.1.

736 See, e.g., BRADY, supra note 643, at 160-61 (discussing debates on drafting of Bill of Rights); Muñoz, supra note 699, at 1085, 1106, 1117-19 (same).

${ }_{737}$ See supra text accompanying notes 698-709.

738 See supra text accompanying notes 696-97.

739 See supra text accompanying notes 684-95 (Locke); supra note 697 (Furneaux); LELAND, The Yankee Spy, supra note 534, at 227-28; see also STILlman, supra note 534, at 27 (rejecting this position as well); Hamburger, Exemption, supra note 643, at 942-46.

7* See Steven J. Heyman, Free Speech and Human Dignity 223 n.54 (2008).

74 494 U.S. 872 (1990). The literature on this issue is voluminous. For some arguments in favor of such a rule, see BRADY, supra note 643; McConnell, supra note 6. For some opposing arguments, see MarCi A. Hamilton, GOD v. ThE Gavel (rev. 2d ed. 2014); Marshall, supra note 15. 
understood the Free Exercise Clause to mandate exemptions, it does show that many people were sensitive to the impact that general laws of this sort could have on the rights of conscience. ${ }^{742}$ This history provides a modicum of support for a rule that would subject such laws to heightened scrutiny, but it provides no more than that. More clearly, it indicates that at this time Americans believed that it was sometimes appropriate for laws or constitutions to grant exemptions under particular circumstances, as several states did for conscientious objection to militia service. ${ }^{7+3}$

\section{Clashes Between Religious Liberty and Civil Rights}

By contrast, the history we have explored sheds considerable light on the problem of conflicts between religious liberty and civil rights. In this section, I first discuss how this history can help us think about cases like Masterpiece Cakeshop Ltd. v. Colorado Civil Rights Commission, ${ }^{74}$ in which weddingrelated businesses with religious objections to same-sex marriage contend that they are entitled to exemptions from state civil rights laws that require them to serve same-sex couples on the same terms as opposite-sex couples. ${ }^{75}$ I then briefly discuss the implications of this history for the case that is before the Court this Term, Fulton v. City of Philadelphia. ${ }^{76}$

One of the clearest teachings of the natural rights/natural religion tradition is that religious liberty may not be used in a way that violates the civil rights of others. ${ }^{77}$ The category of civil rights comprises (1) the natural rights for the

$7: 2$ See supra Part VI.C.

7 See, e.g., Hamburger, Exemption, supra note 643, at 929; supra text accompanying note 700 (listing states whose constitutions granted such exemptions).

$74 \quad 138$ S. Ct. 1719 (2018).

745 For a fuller discussion of the problem, see Steven J. Heyman, A Struggle for Recognition: The Controversy over Religious Liberty, Civil Rights, and Same-Sex Marriage, 14 FIRST AMEND. L. Rev. 1, 100-24 (2015) [hereinafter Heyman, Same-Sex Marriage]. In some cases, the providers also contend that the law violates the Free Speech Clause by compelling them to engage in expression. See, e.g., Masterpiece, 138 S. Ct. at 1723, 1726. I do not address that argument here but limit my discussion to the religious liberty question.

746 104 S. Ct. 1104 (Feb. 24, 2020) (No. 19-123), granting cert. to 922 F.3d 140 (3d Cir. 2019).

747 See, e.g., supra text accompanying notes 95-100, 670 (Locke), 222 (Hutcheson), 242 (Price), 254 (Witherspoon); supra note 417 (Maryland Constitution of 1776). Remarkably, McConnell himself recognizes that this was the accepted view during the founding era. See McConnell, supra note 6, at 1464 (acknowledging that religious liberty gave "a believer . . . no license to invade the private rights 
protection of which individuals enter civil society and (2) the positive benefits they receive as members of society. ${ }^{78}$ Because they are equal by nature and enter society on equal terms, individuals are entitled to equality in civil rights. ${ }^{79}$ Among the most important of these rights is the ability to participate in the economic life of the society. ${ }^{750}$ To bar individuals from equal participation in this economic life is wrongful. And it is even more wrongful when it is based on a notion that they are inherently inferior, for this treats them as though they are not full and equal persons and members of the community. ${ }^{751}$

of others or to disturb public peace and order, no matter how conscientious the belief or how trivial the private right on the other side").

718 See, e.g., 1 Blackstone, Commentaries, supra note 142, bk. I, ch. 1, at 125 (describing civil rights as consisting of "either that residuum ... of natural liberty, which is not required by the laws of society to be sacrificed to public convenience; or else those civil privileges, which society hath engaged to provide, in lieu of the natural liberties so given up by individuals"). As Jefferson and Furneaux make clear, the positive benefits include eligibility to hold positions of public trust. See supra note 471 and accompanying text.

79 See, e.g., Madison, Memorial, supra note 440, $\$ 4$.

750 See LOCKe, GOVERnMent, supra note 30, bk. II, \$130, at 353 (explaining that, by entering civil society, individuals come to enjoy many benefits "from the labour, assistance, and society of others in the same Community").

${ }^{751}$ See Bell v. Maryland, 378 U.S. 226, 311 (1964) (Goldberg, J., concurring). To avoid any misunderstanding, I should make clear that I am not suggesting that religiously motivated refusals to provide wedding-related services to same-sex couples reflect the same sort of hostility that characterizes racial discrimination. On the contrary, such refusals may be based on moral and religious views that are held in good faith. As I have argued at length elsewhere, however, even if an act does not reflect subjective animus toward other persons, it nonetheless may treat them as inherently inferior if as an objective matter it is premised on the view that they lack the moral capacity to engage in an activity of fundamental human importance. Wedding-service providers who refuse for religious reasons to serve same-sex couples do so on the ground that, under the law of God, the individuals involved are not capable of engaging in the fundamental human activity of marrying (in the only way that accords with their sexual orientation). See, e.g., Frequently Asked Questions About the Defense of Marriage, U.S. CONF. OF CATH. Bishops (Sept. 9, 2015), http://www.usccb.org/issues-and-action/marriage-and-family/marriage/promotion-and-defense-ofmarriage/frequently-asked-questions-on-defense-of-marriage.cfm [http://perma.cc/SJ6M-XTSK] (answer to question "Is marriage a basic human right?") ("Relationships between two persons of the same sex are not, and can never be, marriages.”). In this respect, even though the providers may have no subjective animus toward those individuals, they do treat them as objectively inferior in a vital respect. See Heyman, Same-Sex Marriage, supra note 745, at 64-68, 102-10. 
For reasons like these, American law has long held that enterprises that offer to serve the public should be regarded as public accommodations. ${ }^{752}$ Such enterprises must serve everyone on equal terms and may not discriminate on invidious grounds. After the Civil War, many states adopted civil rights laws that prohibited racial discrimination in public accommodations. ${ }^{73}$ Over time, those laws have expanded to include many other forms of discrimination, from religion and gender to veteran and marital status. $^{754}$ In recent years, twenty-five states as well as many localities have banned discrimination based on sexual orientation. ${ }^{755}$ These provisions are rooted in the same view that animates Supreme Court decisions like Romer v. Evans, ${ }^{756}$ Lawrence v. Texas ${ }^{757}$ and Obergefell v. Hodges,${ }^{758}$ which affirm that LGBTQ people have the same inherent rights to freedom, equality, and dignity that all human beings are entitled to. ${ }^{759}$

The implications of this discussion for the wedding-service cases are clear. States are fully justified in adopting civil rights laws that bar public accommodations from discriminating based on sexual orientation. The founding-era history teaches that the right to religious liberty does not authorize one to violate the civil rights of others. It follows that those who operate public accommodations generally have no right to religious exemptions from laws that require them to serve everyone without regard to sexual orientation. ${ }^{760}$

752 On the history and theory of this right, see generally Heyman, Same-Sex Marriage, supra note 745, at 79-89; Joseph William Singer, No Right to Exclude: Public Accommodations and Private Property, 90 Nw. U.L. REv. 1283 (1996).

753 See Singer, supra note 752, at 1357-67, 1374-83.

${ }^{734}$ See Lisa Gabrielle Lerman \& Annette K. Sanderson, Note, Discrimination in Access to Public Places: A Survey of State and Federal Public Accommodations Laws, 7 N.Y.U. Rev. L. \& Soc. Change 215, 260-72 (1978).

${ }_{755}$ See State Public Accommodation Laws, National Conference OF State Legislatures, https://www.ncsl.org/research/civil-and-criminal-justice/state-public-accommodation-laws.aspx [https://perma.cc/E3QF-89T4].

7565 U.S. $620(1996)$.

$757 \quad 539$ U.S. $558(2003)$.

738 S. Ct. 2584 (2015).

$759 \quad$ See, e.g., id. at 2593, 2599-605, 2608.

${ }^{760}$ For discussion of some appropriate exceptions to this general rule, see Heyman, Same-Sex Marriage, supra note 745, at 110, 112-17. 
An important caveat is in order. Although I have argued that weddingservice providers generally are not entitled to demand a religious exemption, that does not necessarily mean that the government may not grant one. For instance, a legislature may consider whether to provide certain exemptions as a matter of prudence (say, to avoid a backlash against same-sex marriage by giving the public time to become used to it) or for the sake of compromise (say, by granting religious traditionalists certain exemptions in return for their support for adding sexual orientation protections to a civil rights law that currently lacks them ${ }^{761}$ ). Exemptions of this sort may be acceptable insofar as they advance the ultimate goal of ensuring equality for all. But while such practical considerations may be taken into account by legislatures, courts should be governed by principle when they interpret the Constitution.

In Masterpiece, the Court articulated an approach that resembles the one suggested here. Writing for the majority, Justice Kennedy declared that "[o]ur society has come to the recognition that gay persons and gay couples cannot be treated as social outcasts or as inferior in dignity and worth. ${ }^{{ }^{62} 2}$ States act on this principle when they require public accommodations to serve everyone without regard to sexual orientation. ${ }^{763}$ Although "religious and philosophical objections" may be protected by the First Amendment, "it is a general rule that such objections do not allow business owners and other actors in the economy and in society to deny protected persons equal access to goods and services under a neutral and generally applicable public accommodations law." ${ }^{\text {"64 }}$ Kennedy left open the possibility that some providers, such as bakers who create custom cakes with religious symbols, might be entitled to a free exercise exemption. ${ }^{765}$ But he cautioned that any such exemption

would have to be sufficiently constrained, lest all purveyors of goods and services who object to gay marriages for moral and religious

${ }^{761}$ See id. at 123-24 (discussing recent compromise on housing and employment discrimination in Utah).

702 Masterpiece Cakeshop, Ltd. v. Colo. Civ. Rights Comm'n, 138 S. Ct. 1719, 1727 (2018).

763 See id. at 1728.

764 Id. at 1727 (citations omitted). Kennedy's opinion was joined by Chief Justice Roberts and Justices Ginsburg, Breyer, Kagan, and Gorsuch. See id. at 1722. The principles just quoted were also endorsed by the dissent, see id. at 1748 (Ginsburg, J., joined by Sotomayor, J., dissenting), and so would appear to represent the views of at least eight Justices then on the Court.

${ }_{765} \quad$ See id. at $1723-24,1728$. 
reasons in effect be allowed to put up signs saying "no goods or services will be sold if they will be used for gay marriages," something that would impose a serious stigma on gay persons. ${ }^{766}$

The conflict between civil rights and religious liberty is once again before the Supreme Court in Fulton v. City of Philadelphia. ${ }^{767}$ In that case, the city contracted with private organizations to certify individuals and couples to serve as foster parents. ${ }^{768}$ After Catholic Social Services (CSS) stated that for religious reasons it would not consider same-sex couples for this role, the city terminated its contract with the organization for noncompliance with the city's nondiscrimination policy. ${ }^{769}$ CSS's free exercise challenge to that decision was rejected by the district court ${ }^{770}$ as well as by the United States Court of Appeals for the Third Circuit. ${ }^{771}$ The Supreme Court heard argument in this case in November 2020, with a decision expected later this Term. ${ }^{772}$

The view that I have outlined suggests a way of approaching the problem presented in cases like Fulton. The concept of civil rights includes equal access to the benefits that society provides its members, including eligibility to hold positions of authority or service within the community. ${ }^{773}$ Thus, when the government establishes a foster-care program, it should not bar otherwise qualified couples from serving as foster parents based on traits like race, gender, religion, or sexual orientation. This principle clearly would apply if the government itself undertook to certify foster parents. By the same token, when the government contracts with private organizations to perform this function, it may insist that they comply with the same nondiscrimination requirements that would apply to the government itself. The right to religious liberty does not entitle organizations to demand an exemption from such

${ }_{766} I d$. at 1728-29. The Court ultimately ruled for the baker, however, on the narrow ground that the state civil rights commission had failed to consider his case in the atmosphere of religious neutrality that the Free Exercise Clause demands. See id. at 1729-32.

767 922 F.3d 140 (3d Cir. 2019), cert. granted, 140 S. Ct. 1104 (Feb. 24, 2020) (No. 19-123).

${ }_{708} \quad$ See id. at $147-48$.

${ }^{769} \quad$ See id. at $148-51$.

$770 \quad$ Fulton v. City of Phila., 320 F. Supp. 3d 661, 691 (E.D. Pa. 2018).

771 Fulton, 922 F.3d at 160.

772 For the briefs and a transcript of oral argument, see Fulton v. City of Philadelphia, Pennsylvania, SCOTUSBLOG, https://www.scotusblog.com/case-files/cases/fulton-v-city-of-philadelphiapennsylvania/ (last visited November 13, 2020).

$773 \quad$ See supra text accompanying note $677,748-49$. 
requirements, which are adopted to protect the civil rights of prospective foster parents. Surely this is the position we would take if an organization refused to certify interracial couples for this role, and it is difficult to see why a different rule should apply in cases involving same-sex couples. Again, there may be circumstances in which a government reasonably could choose to grant an exemption to religious organizations-say, if there were plenty of other groups who were willing to work with same-sex couples and an exemption would benefit the foster-care system as a whole. ${ }^{774}$ But the history we have explored counsels against interpreting the Free Exercise Clause to allow the right to religious liberty to trump the civil rights of other members of the community.

\section{CONCLUSION}

In this Article, I have argued that the eighteenth-century American conception of religious liberty was deeply informed by the concepts of natural religion, natural law, and natural rights. In its widely accepted form, natural religion did not refer to a particular belief system that stood in contrast to other systems like traditional Christianity. Instead, natural religion offered an account of the nature of religion. ${ }^{775}$ Religion was rooted in the relationship between God and the rational beings he had created. In the words of the Virginia Declaration of Rights, this relationship could be based only on "reason and conviction," and so individuals had an inalienable right to form and express their own beliefs and to worship and act in accord with them. ${ }^{776}$ This broad view was endorsed by a wide range of people from Deists like Thomas Jefferson and Benjamin Franklin, to rationalist Christians like Jonathan Mayhew and James Maury, to Evangelicals like John Leland and Isaac Backus. It was incorporated in key documents such as the state declarations of rights, Jefferson's Bill for Establishing Religious Freedom, Madison's Memorial and Remonstrance, Evangelical petitions against the Assessment Bill, and the religious liberty proposals that emerged from the state ratifying conventions-documents that in turn provide great insight into the ideas that underlie the First Amendment's Free Exercise Clause.

77 Cf. supra text accompanying note 761 (discussing potential exceptions to public accommodations laws).

775 See BYRne, supra note 15.

776 VA. DEClaRATION OF RigHTS, supra note 1, art. 16. 
In addition to explicating the nature of religion and the justification for religious liberty, natural religion offered an account of the most fundamental substantive principles of religion. According to this account, reason taught that human beings were created by God and had a duty to worship and obey him. God's will could be found in what the Declaration of Independence called "the Laws of Nature and of Nature's God" -laws that established the inherent rights of individuals and the duties they owed one another. This view of the principles of natural religion held a central place in many fields of eighteenthcentury thought including political theory, natural jurisprudence, AngloAmerican law, moral philosophy, natural science, and Radical Whig ideology.

In this way, natural religion and its associated ideas profoundly shaped the worldview of Americans during the founding era. Within this general view there were marked differences. Deists like Jefferson believed that religion should be based on reason alone. By contrast, most Americans followed Locke in holding that both reason and revelation were essential and that they provided complementary means of discerning God's will. This position allowed the idea of natural religion to be widely held in a country in which most inhabitants were Christians, and it enabled that concept to establish common ground between different denominations of Christians as well as between Christians and non-Christians.

At the same time that it illuminates the intellectual world of eighteenthcentury Americans, our exploration of this history underscores the great distance that lies between their world and our own. Natural religion found support in the leading scientific and philosophical views of founding period. After the rise of Darwinian evolutionary theory and other modern scientific developments, it is no longer widely accepted that human beings can rely on reason alone to establish the existence of God or the moral laws of nature. Instead, as Charles Taylor has written, we now "live in a secular age" in which the status of religious beliefs is far more controversial. ${ }^{778}$

It follows that the ideas about religion that flourished during the founding era cannot be applied in any straightforward way today. Instead, the question of whether and how those ideas can be translated to our own context is one that calls for much careful consideration. Of course, this is not the place to

77 DeClaration OF INDEPENDENCE, supra note 372.

778 Charles Taylor, A Secular Age 1 (2007). 
embark upon such an inquiry. But some present-day lessons do emerge from the history we have explored. First, the Free Exercise Clause was primarily based not on an Evangelical commitment to the promotion of Christianity but on the idea that all human beings should be free to use their own minds in religious matters. This is the light in which it should be understood.

Second, the history sheds some valuable light on our current debates over exemptions. It is difficult to find any eighteenth-century support for a general principle that religious believers have a right to exemption from civil laws. However, there was at least one context-military service-in which many people found a claim to religious exemption sympathetic. In view of this history, it is an open question whether the Supreme Court should adopt a rule applying some form of heightened scrutiny to laws like the one at issue in Employment Division v. Smith-a law that imposed a substantial burden on a group's religious practice merely to promote the state's view of public welfare. But civil rights laws present a very different issue. One of the clearest lessons that emerge from the history is that the right to religious liberty does not authorize conduct that violates the civil rights of other people. This suggests that the Masterpiece Court was right when it articulated a general approach along these lines. It is in this way that we can best realize the founders' vision of a society in which all of the "rights of mankind" are fully protected. ${ }^{779}$

Jefferson Bill, supra note 469; Madison, Bill of Rights Speech, supra note 610, at 24. 
